UNIVERSIDADE DE SÃO PAULO

FACULDADE DE EDUCAÇÃO

SABRINA LEONZI D’ALESSANDRO

\title{
A REBELIÃO DOS PEQUENOS COPISTAS \\ Marcas de reescrita em textos produzidos por crianças
}

São Paulo

2020 


\section{A REBELIÃO DOS PEQUENOS COPISTAS}

Marcas de reescrita em textos produzidos por crianças

Dissertação apresentada à Faculdade de Educação da Universidade de São Paulo para obtenção do título de Mestre em Educação.

Área de concentração: Educação, Linguagem e Psicologia

Orientadora: Profa. Livre-Docente Claudia Rosa Riolfi.

São Paulo

2020 
AUTORIZO A REPRODUÇÃO E DIVULGAÇÃO TOTAL OU PARCIAL DESTE

TRABALHO, POR QUALQUER MEIO CONVENCIONAL OU ELETRÔNICO, PARA

FINS DE ESTUDO E PESQUISA, DESDE QUE CITADA A FONTE.

Catalogação da Publicação

Ficha elaborada pelo Sistema de Geração Automática a partir de dados fornecidos pelo(a) autor(a)

Bibliotecária da FE/USP: Nicolly Soares Leite - CRB-8/8204

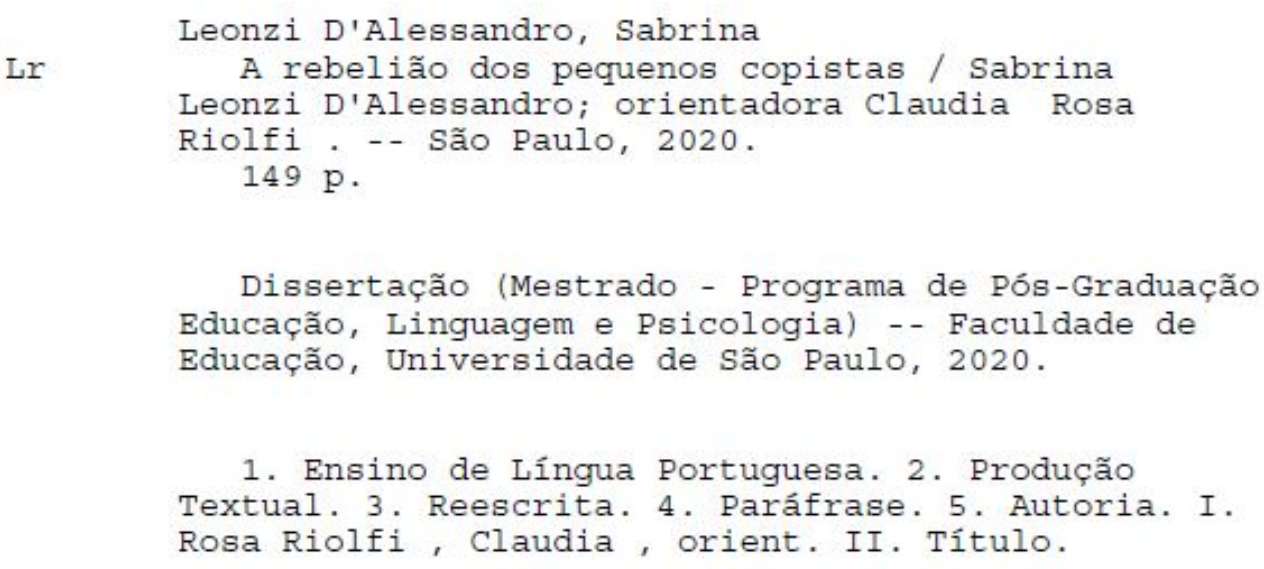




\section{FOLHA DE APROVAÇÃO}

Sabrina Leonzi D'Alessandro

A rebelião dos pequenos copistas: marcas de reescrita em textos produzidos por crianças

Dissertação apresentada à Faculdade de Educação da Universidade de São Paulo para obtenção do título de Mestre em Educação.

Área de concentração: Educação, Linguagem e Psicologia

Aprovada em:

Banca examinadora

\section{Prof. ${ }^{\text {a Livre-Docente Claudia Rosa Riolfi (Orientadora) }}$}

Faculdade de Educação, Universidade de São Paulo

Assinatura:

Prof. Dr. Paulo Roberto Gonçalves Segundo

Faculdade de Filosofia, Letras e Ciências Humanas, Universidade de São Paulo Assinatura:

\section{Prof. ${ }^{a}$ Dr. ${ }^{a}$ Emari Andrade de Jesus}

Instituto Federal de São Paulo

Assinatura: 
Membros suplentes

\section{Prof. ${ }^{\text {a }}$ Livre-Docente Silvia de Mattos Gasparian Colello}

Faculdade de Educação, Universidade de São Paulo

Assinatura:

Prof. $^{\text {a }}$ Dr. ${ }^{\text {a }}$ Fraulein Vidigal de Paula

Instituto de Psicologia, Universidade de São Paulo

Assinatura:

\section{Prof. ${ }^{a}$ Dr. ${ }^{a}$ Mical de Melo Marcelino}

Instituto de Ciências Humanas, Universidade Federal de Uberlândia

Assinatura: 
À Angela, ao Renato, ao Leo e ao Henrique, por todo o amor. 


\section{Agradecimentos}

À professora Claudia Rosa Riolfi, pela orientação paciente e afetuosa desde a graduação e por todos esses anos.

Aos professores Paulo Roberto Gonçalves Segundo e Adriana Santos Batista, pela leitura atenta da dissertação por ocasião do exame de qualificação. Suas observações muito contribuíram para a finalização deste trabalho.

Aos meus pais, que antes de mim acreditaram neste sonho e cujo apoio e carinho me impulsionaram.

Ao meu irmão e melhor amigo, pelo companheirismo mesmo quando um oceano nos separou.

Ao Henrique, pela parceria e pelo cuidado. Agradeço pelas leituras deste texto e por compreender minhas ausências.

À Ilda, pela inspiração.

À Fatima, pela amizade sincera.

Ao Alex, ao Felipe e ao Henrique Moura, pela força nos momentos de crise.

Aos colegas do GEPPEP, por tudo o que aprendemos juntos. Em especial, agradeço à Renata, que tantas dúvidas minhas esclareceu, pela generosidade; ao Carlos, pelas conversas sobre pesquisa, trabalho e vida acadêmica; à Juliana, à Tatiane e ao Júlio, pelas cuidadosas sugestões feitas por ocasião da "banquinha".

À Ciça, pela revisão minuciosa desta dissertação.

À equipe docente da Escola de Aplicação da FE-USP, por tornar possível a coleta dos dados desta pesquisa. 
Às crianças, pela magia.

Aos familiares e amigos, pela constante torcida.

Aos funcionários da Seção de Pós-Graduação da FE-USP, pela prontidão. 


\section{RESUMO}

D'ALESSANDRO, Leonzi Sabrina. A rebelião dos pequenos copistas: marcas de reescrita em textos produzidos por crianças. 2020. 149 f. Dissertação (Mestrado) - Faculdade de Educação, Universidade de São Paulo, São Paulo, 2020.

Esta pesquisa partiu de um interesse em conhecer o que se passa quando crianças matriculadas no terceiro ano do Ensino Fundamental I de uma escola pública,localizada na zona oeste da capital de São Paulo, atendem à solicitação de reproduzir, o mais fielmente possível, textos-fonte cuja leitura em voz alta, por parte de suas professoras, acabaram de seguir. A pesquisa assumiu os seguintes objetivos específicos: a) Minuciar as operações sistemáticas da escritura utilizadas pelos participantes para reescrever textos-fonte; b) Examinar a presença de autoria em textos que são fruto da reescrita de textos-fonte; e c) Analisar as especificidades dos textos gerados pela reescrita de diferentes textos-fonte. Para tanto, o trabalho explorou um corpus de 236 manuscritos produzidos por 59 crianças distribuídas em quatro turmas. $\mathrm{O}$ grupo de alunos, à época da coleta, era formado por vinte e oito meninas e trinta e um meninos, em sua maioria com idade de oito anos e pertencentes à classe média-baixa. Todos os textos foram escritos por ocasião das avaliações trimestrais aplicadas em sala de aula. O trabalho analítico de cotejamento entre os textos-fonte e as reescritas dos mesmos iniciou-se por um levantamento quantitativo que tomou como unidade a primeira sentença dos textos-fonte. Observamos as ocasiões em que os participantes não alteraram o texto-fonte, tendo conseguido reter na memória grandes porções da formulação original, e as ocasiões em que lançaram mão das operações sistemáticas de escritura (GRÉSILLON; LEBRAVE, 1983; GRÉSILLON, 2007): adição (inserção de palavras, sintagmas ou frases), deslocamento (transposição de uma parte do texto de um lugar para outro), substituição (troca de uma parte do texto por outra) e supressão (abandono de uma parte do texto). A análise resultou na presença das quatro operações sistemáticas da escritura. Houve prevalência de supressões e substituições, seguidas pelos acréscimos. A ocorrência de deslocamentos foi pequena, superando apenas o número de reproduções fiéis. A segunda análise elegeu o texto como objeto e teve caráter qualitativo. Nos textos examinados, buscamos localizara presença de um sujeito que não tivesse deixado se anular em benefício da função de aluno ao aceitar a proposta de exercício de reprodução dos textos-fonte. A presença dos seguintes elementos na obra original parece ter facilitado o advento de textos que não se limitaram a reproduzir os textos-fonte: 1) Afirmações de caráter ideológico que, ao provocar discordância por parte das crianças, deram origem a produções dissonantes; 2) Termos e referências incomuns ao universo das crianças participantes, que deram origem a substituições e supressões; 3) Partes aflitivas que tendem a ser suprimidas; e 4) Descrição das qualidades positivas ou negativas dos protagonistas, aos quais as crianças tendem a destinar castigos ou recompensas. $\mathrm{O}$ conjunto da pesquisa indica que, mesmo em tarefas de caráter predominantemente parafrástico, os participantes acabam gerando efeitos de sentido que, junto ao leitor, se configuram como autorais. Entre repetir exatamente o que leram e retomar de maneira diferenciada, as crianças tendem para o segundo movimento, dando vistas de que estão continuamente interpretando os textos dados a ler.

Palavras-chave: Ensino de Língua Portuguesa; Produção Textual; Reescrita; Paráfrase; e Autoria. 


\begin{abstract}
D'ALESSANDRO, Leonzi Sabrina. The rebellion of small copyists: marks of rewriting in texts produced by children. 2020. 149 f. Dissertação (Mestrado) - Faculdade de Educação, Universidade de São Paulo, São Paulo, 2020.
\end{abstract}

This research started due to the interest in finding out the outcomes when third-grade children enrolled in a public school, located in the west area in the city of São Paulo, were asked to reproduce, as detailed as possible, mentor texts used in read aloud sessions conducted by their teachers. The research assumed the following specific objectives: a) To minimize the systematic operations in writing produced by the participants to rewrite mentor texts; $b$ ) Examine the presence of authorship in texts that are the result of the rewriting of mentor texts; and c) Analyze the specificities of the texts resulting the process of rewriting different mentor texts. To this end, this research explored a corpus comprised of 236 manuscripts produced by 59 children distributed in four classes. At the time of data collection, the group of students was formed by twenty-eight girls and thirty-one boys, most of them aged eight years old and belonging to the lower middle class. All texts were written during the quarterly evaluations applied in the classroom. The analytical work of comparing the mentor texts and their rewriting pieces began with a quantitative survey that considered as a unit the first sentence of the mentor texts. We looked in which occasions the participants did not change the mentor text, as they managed to retain large portions of the original formulation in their memory, as well as the occasions when they used systematic writing operations (GRÉSILLON; LEBRAVE, 1983; GRÉSILLON, 2007): addition (insertion of words, syntagma or phrases), displacement (transposition of a part of the text from one place to another), substitution (exchange of a part of the text for another) and deletion (abandonment of a part of the text). The analysis resulted in the presence of the four systematic operations in writing. There was a prevalence of deletions and substitutions, followed by additions. Displacements occurred fewer times, surpassing only by the number of detailed reproductions. The second analysis aimed at the text as the object of a qualitative study. In the examined texts, we aimed to locate the presence of a subject who had not allowed himself to be annulled in favor of the student function by accepting the proposal to exercise the reproduction of the mentor texts. The presence of the following elements in the original work seems to have facilitated the advent of texts that were not limited to reproducing the mentor texts: 1) Statements of ideological features causing reactions of disagreement among the children led them to dissonant productions; 2) Unusual terms and references to the universe of the children participating in this study led them to substitutions and deletions; 3) Afflicting parts that tend to be suppressed; and 4) Description of the positive or negative qualities of the protagonists, to which children tend to give sanctions or rewards. The research as a whole indicates that, even in tasks of a predominantly paraphrase nature, the participants end up generating effects in meaning that, alongside with the reader, are construed as authors. Having the choices of repeating exactly what they read and summarizing it in a different way, children tend to the second movement, giving the impression that they are continuously interpreting the texts they were given to read.

Keywords: Portuguese Language Teaching; Textual Production; Rewriting; Paraphrasing; and Authorship. 


\section{Lista de figuras}

\begin{tabular}{|l|c|}
\hline Figura 1 - Imagens norteadoras para a reescrita do texto "A rainha da bateria" & 39 \\
\hline Figura 2 - Agrupamento dos textos constituintes do corpus por turma participante & 53 \\
\hline Figura 3 - Agrupamento dos textos constituintes do corpus por texto-fonte reescrito & 54 \\
\hline $\begin{array}{l}\text { Figura } 4 \text { - Introdução à atividade com o texto "Maria Angula (Equador)" contida } \\
\text { no Caderno da Cidade }\end{array}$ & 96 \\
\hline $\begin{array}{l}\text { Figura 5 - Sistematização de conteúdos durante atividade proposta pelo Caderno } \\
\text { da Cidade }\end{array}$ & 99 \\
\hline $\begin{array}{l}\text { Figura 6 - Discussão proposta pelo Caderno da Cidade a partir da leitura de "Maria } \\
\text { Angula (Equador)" }\end{array}$ & 101 \\
\hline
\end{tabular}




\section{Lista de quadros}

\begin{tabular}{|c|c|}
\hline Quadro 1 - Fragmento do texto-fonte "A rainha da bateria" & 60 \\
\hline $\begin{array}{l}\text { Quadro } 2 \text { - Manuscrito e transcrição diplomática de fragmento da reescrita produzida } \\
\text { por J. }\end{array}$ & 60 \\
\hline $\begin{array}{l}\text { Quadro } 3 \text { - Manuscrito e transcrição diplomática de fragmento da reescrita produzida } \\
\text { por S. }\end{array}$ & 60 \\
\hline Quadro 4 - Fragmento do texto-fonte "João-de-barro" & 63 \\
\hline $\begin{array}{l}\text { Quadro } 5 \text { - Manuscrito e transcrição diplomática de fragmento da reescrita produzida } \\
\text { por A. }\end{array}$ & 63 \\
\hline Quadro 6 - Trecho suprimido do texto-fonte "Maria Angula (Equador)" & 66 \\
\hline Quadro 7 - Fragmento do texto-fonte "Uma festa muito esperada" & 68 \\
\hline $\begin{array}{l}\text { Quadro } 8 \text { - Manuscrito e transcrição diplomática de fragmento da reescrita produzida } \\
\text { por M. }\end{array}$ & 69 \\
\hline $\begin{array}{l}\text { Quadro } 9 \text { - Ocorrência de operações sistemáticas da escritura nas quatro atividades } \\
\text { propostas }\end{array}$ & 71 \\
\hline Quadro 10 - Reescrita de "A rainha da bateria" produzida por R. & 75 \\
\hline $\begin{array}{l}\text { Quadro } 11 \text { - Transcrição diplomática da reescrita de "A rainha da bateria" produzida } \\
\text { por R. }\end{array}$ & 76 \\
\hline Quadro 12 - Segmentos do texto-fonte restaurados pela participante da pesquisa & 77 \\
\hline Quadro 13 - Cotejamento entre excerto do texto-fonte e sua reescrita & 79 \\
\hline $\begin{array}{l}\text { Quadro } 14 \text { - Reescrita de "A rainha da bateria" produzida por A. e transcrita pela } \\
\text { autora }\end{array}$ & 81 \\
\hline $\begin{array}{l}\text { Quadro } 15 \text { - Reescrita de "A rainha da bateria" produzida por F. e transcrita pela } \\
\text { autora }\end{array}$ & 84 \\
\hline Quadro 16 - Cotejamento entre excerto do texto-fonte e sua reescrita & 85 \\
\hline
\end{tabular}




\begin{tabular}{|c|c|}
\hline $\begin{array}{l}\text { Quadro } 17 \text { - Reescrita de "A rainha da bateria" produzida por S. e transcrita pela } \\
\text { autora }\end{array}$ & 86 \\
\hline Quadro 18 - Reescrita de "João-de-barro" produzida por C. e transcrita pela autora & 89 \\
\hline Quadro 19 - Reescrita de "João-de-barro" produzida por I. e transcrita pela autora & 91 \\
\hline Quadro 20 - Reescrita de "João-de-barro" produzida por P. e transcrita pela autora & 93 \\
\hline $\begin{array}{l}\text { Quadro } 21 \text { - Reescrita de "Maria Angula (Equador)" produzida por G. e transcrita } \\
\text { pela autora }\end{array}$ & 104 \\
\hline $\begin{array}{l}\text { Quadro } 22 \text { - Reescrita de "Maria Angula (Equador)" produzida por H. e transcrita } \\
\text { pela autora }\end{array}$ & 106 \\
\hline $\begin{array}{l}\text { Quadro } 23 \text { - Reescrita de "Maria Angula (Equador)" produzida por L. e transcrita } \\
\text { pela autora }\end{array}$ & 109 \\
\hline $\begin{array}{l}\text { Quadro } 24 \text { - Reescrita de "Uma festa muito esperada" produzida por D. e transcrita } \\
\text { pela autora }\end{array}$ & 112 \\
\hline Quadro 25 - Cotejamento entre início de parágrafo do texto-fonte e sua reescrita & 114 \\
\hline $\begin{array}{l}\text { Quadro } 26 \text { - Reescrita de "Uma festa muito esperada" produzida por M. e transcrita } \\
\text { pela autora }\end{array}$ & 117 \\
\hline $\begin{array}{l}\text { Quadro } 27 \text { - Reescrita de "Uma festa muito esperada" produzida por O. e transcrita } \\
\text { pela autora }\end{array}$ & 119 \\
\hline
\end{tabular}


Lista de gráficos

Gráfico 1 - Ocorrência de operações sistemáticas da escritura na reescrita de "A rainha da bateria" (VILA, 2009)

Gráfico 2 - Ocorrência de operações sistemáticas da escritura na reescrita de "Joãode-barro" (SÓHISTÓRIA, 2019)

Gráfico 3 - Ocorrência de operações sistemáticas da escritura na reescrita de "Maria Angula (Equador)" (URIBE, 1999)

Gráfico 4 - Ocorrência de operações sistemáticas da escritura na reescrita de "Uma 67 festa muito esperada" (TOLKIEN, 2001) 


\section{SUMÁRIO}

Introdução

1. Aprender a escrever no terceiro ano do Ensino Fundamental: um sobrevoo

1.1 Bairro e escola

1.2 Os terceiros anos do Ensino Fundamental

1.3 Método de coleta dos dados

1.3.1 O projeto "Reescrita e manejo da diferença no $3^{\circ}$ ano do Ensino 32 Fundamental"

1.3.2 A autoria nos documentos relacionados à pesquisa

1.3.3 Os participantes da pesquisa

1.3.4 Descrição do corpus

2. Reescrita e autoria no Ensino Fundamental I: duas faces de uma mesma moeda?

2.1 Nossa concepção de linguagem

$2.2 \mathrm{O}$ conceito operacional de autoria com o qual trabalhamos

2.2.1 A autoria enquanto indício

2.2.2 A autoria enquanto posicionamento subjetivo

2.2.3 A autoria enquanto estilo

2.3 Reformulações parafrásticas como objeto de estudo

2.3.1 Retomar um texto-fonte é reformulá-lo

2.3.2 Entre o mesmo e o novo

3. As operações sistemáticas da escritura

3.1 A organização do corpus e seu recorte 
3.3 Análise quantitativa das operações sistemáticas da escritura

3.4“Chatas, ricas e mimadas": uma aposta na manifestação da autoria

4. Os textos-fonte e os produtos deles advindos

4.1 Desafios de repertório em "A rainha da bateria"

4.2 Retomadas literais em "João-de-barro"

4.3 Apropriação do castigo em "Maria Angula (Equador)"

4.4 Resgate e aproximação em "Uma festa muito esperada"

4.5 Uma primeira síntese

Considerações finais

Referências bibliográficas

Anexos 


\section{Introdução}

Nosso estudo voltou-se à análise de 236 redações, produzidas — a partir da solicitação de professoras regentes de quatro turmas de terceiro ano do Ensino Fundamental, em escola pública estadual situada na zona oeste da capital paulista - por crianças de oito anos durante o cotidiano das aulas. Elas originaram-se de exercícios cujos comandos solicitavam a reescrita fiel e sem consulta de textos-fonte selecionados pelas professoras.

Devido ao que orientam os documentos oficiais (BRÄKLING, 2013), os exercícios de refacção de textos-fonte são comumente propostos a estudantes recém-alfabetizados nas salas de aula brasileiras. A alegação é aquela segundo a qual, em atividades desse tipo, o aluno não precisa produzir o conteúdo temático, o que facilitaria a tarefa de aquisição da ortografia, morfologia etc.

Consequentemente, nas turmas observadas durante a pesquisa que deu origem à presente dissertação, não havia investimento na dimensão autoral da escrita. A expectativa das professoras regentes era de que as crianças reescrevessem textos ficcionais da esfera literária (como fábulas, contos e trechos de romance) o mais próximo possível do texto-fonte. Por isso, pode parecer que esse tipo de atividade dê origem a produções textuais nas quais de fato predomine a reprodução dos textos-fonte, sem que haja espaço para eclodir algo da subjetividade dos alunos.

Interessadas em conhecer o que se passa quando é solicitado que crianças recémalfabetizadas reproduzam, de memória, textos-fonte que acabaram de ler e escutar, buscamos analisar a distância existente entre eles e o que foi escrito pelos estudantes em termos de transformações linguístico-discursivas.

Nessa análise, privilegiamos a inserção de palavras, sintagmas ou frases, a transposição de uma parte do texto de um lugar para outro, a troca de uma parte do texto por outra e o abandono de uma parte do texto, ou seja, as operações sistemáticas de escritura (adição, deslocamento, substituição e supressão, respectivamente) (GRÉSILLON; LABRAVE, 1983; GRÉSILLON, 2007).

Para Geraldi (1985), é comum que, na prática escolar, haja uma anulação do sujeito em benefício da função que exerce, sendo o "eu" e o "tu" do discurso sempre os mesmos. De acordo com o autor, o uso da língua no espaço escolar é artificial. Em sua avaliação, na escola não se escrevem textos, mas produzem-se redações, produções em que não se dá o "uso efetivo e concreto da linguagem com fins determinados pelo locutor" (GERALDI, 1985, p. 
79) e que servem de preparação para o futuro, "encarando-se o hoje como não-vida" (GERALDI, 1985, p. 121). Assim, para que se produzissem textos, seria preciso que os alunos tivessem não só “o que dizer”, mas também “uma razão para dizer” e um interlocutor "para quem dizer", bem como que se instituíssem enquanto "sujeito que diz o que diz para quem diz" e escolhessem “estratégias” para alcançar tudo isso (GERALDI, 1997, p. 137).

Levando essa distinção em conta, poder-se-ia dizer que a pesquisa que deu origem à presente dissertação tomou como objeto as transformações linguístico-discursivas efetuadas por alunos durante a escrita de redações, em relação a textos lidos previamente. O termo "redação" (GERALDI, 1985) caberia nesse caso porque as referidas transformações surgiram em produções escritas frutos de exercício que consistia em ler um texto ficcional da esfera literária (que aqui chamaremos de texto-fonte), às vezes individualmente, às vezes coletivamente, responder algumas questões dissertativas referentes a ele e, quase sempre após a (segunda) leitura em voz alta da professora, reescrevê-lo do modo mais fiel possível ao original.

Outro modo de classificar essas produções seria nomeando-as como "manuscritos escolares", textos produtos de atividades que têm a instituição escola como cenário (CALIL, 2008, p. 25). Classicamente, tais objetos têm sido descritos: a) pela predominância de uma "voz que devolve, re-produz a fala do eu-professor-escola" (GERALDI, 1985, p. 78); e b) por um tipo de relação do sujeito com a palavra que mais parece o "preenchimento de um arcabouço ou esquema" (GERALDI, 1985, p. 123), sem estabelecimento de interlocução com um possível leitor.

Já faz alguns anos que práticas nas quais as crianças necessitam de autorização para se expressar têm sido questionadas. Em 1988, observando casos extremos de fracasso escolar, Patto (2015) afirma que, em muitas salas de aula, a produção escrita criativa é praticamente proibida, uma vez que as crianças limitam-se a repetir os dizeres da professora sob pena de serem castigadas. Escrever e desenhar significa, para esses alunos, reproduzir o mais fielmente possível figuras e textos apresentados a eles como modelos. Por isso, há um grande esforço de memória para resgatar detalhes e as produções caracterizam-se pela estereotipia. No entanto, a despeito de inúmeras tentativas, a pesquisadora conclui que essas atividades, somadas à burocracia, chegam a "amordaçar" o sujeito, mas não podem "eliminá-lo" (PATTO, 2015, p. 363).

À conclusão semelhante chega Smolka (1988), cuja obra, contemporânea à de Patto, defende uma proposta político-pedagógica de alfabetização como processo discursivo que 
potencializa a função transformadora da linguagem, vista como uma forma de interação no contexto escolar. Segundo ela, assumindo o papel de escritora, a criança inevitavelmente expõe um ponto de vista e revela imagens, pressuposições e regras de comportamento social.

De modo análogo às autoras, não acreditamos que a pressão para obtenção de uma nota e o receio de um parecer negativo vindo do educador impeçam a produção criativa do aluno, embora possivelmente a reduzam. Alegar o contrário, afirmando que as composições infantis em contexto escolar limitam-se à tentativa, por parte das crianças, de evitar riscos e controlar o resultado das avaliações, significaria defender uma opinião excessivamente determinista.

Ademais, se entendemos a leitura não como um processo de decifração ou adivinhação de sentidos, mas de atribuição de significações e de estabelecimento de relações com outros textos significativos para o leitor, que se entrega à leitura prevista pelo autor ou rebela-se contra ela, propondo outra, pode-se falar em leituras possíveis, sendo a do professor, testemunha do diálogo texto-aluno, apenas uma delas (LAJOLO, 1982, p. 59; GERALDI, 1985, p. 80).

Assim, compreendemos que as operações efetuadas pelo sujeito com e sobre a linguagem podem, ao menos potencialmente, abrir espaço para a ruptura com a palavra cotidiana. Na singularidade de cada acontecimento discursivo, novos recursos expressivos constituem-se a partir dessas operações (GERALDI, 1997, p. 226). Portanto, acreditamos que uma relativa liberdade criativa pode ocorrer mesmo quando, em ambiente escolar, crianças são solicitadas a desempenhar atividades predominantemente parafrásticas.

Nessas atividades, a sensação de "resposta certa a ser dada" suscitada em alunos convidados a desempenhar a reescrita de textos previamente lidos nos diz muito a respeito das posições ocupadas por eles e por seus professores frente à demanda educativa.

Considerando que o presente estudo se interessa pelos modos como as crianças investigadas se lançam a dizer em seus textos, cabem algumas ponderações sobre o modo como se dão tais posicionamentos no contexto escolar, que nos serve de panorama.

Para Lajonquière (2013, p. 463), o adulto em função de professor "deve se lançar à fala, à enunciação, à palavra". Isso significa que ele tanto produz sentenças quanto prega verdades que se fizeram suas no momento em que se deu sua formação. Enquanto professa, tem quem lhe preste atenção. Ocupa, portanto, o lugar de mestre falante diante dos discípulos mudos. Se ele é "sujeito de um (e num) discurso", o outro é, em alguma medida, "infans privado de palavra nos assuntos professados pelo mestre de plantão". 
Nessa configuração, o ponto de vista do adulto - ou "o desejo que anima a demanda educativa" (LAJONQUIÈRE, 2003) - escapa à criança. Ela passa a supor, no seu inconsciente, que o adulto sabe viver. Além disso, passa a desejar o saber sobre o desejo, que supostamente pertence "aos grandes", chegando às vezes a entrar "no mundo dos velhos".

Quando, entretanto, a pedagogia moderna aposta na possibilidade de controlar o processo educativo, o ato do adulto passa a balizar-se por manuais de instrução, de modo que a criança preenche o lugar de objeto do discurso, ou seja, é impedida de se constituir como sujeito do desejo. Isso porque o educador, se iludido, crê que as crianças representam a esperança de felicidade, de plenitude, não permitindo que lhes falte nada (LAJONQUIÈRE, 1999). Assim, ele não exerce sua responsabilidade pelo ato (e pelas palavras) e não opera a arbitrariedade inerente ao desejo. Todavia, é justamente graças a essa arbitrariedade, ligada a uma tradição, que uma janela é deixada aberta para que a criança se pergunte "o que será que esses adultos querem de mim?" e surja, então, o desejo. A criança chega a um lugar de falta. Porém, se o outro não sonha, ninguém lhe abre a porta. Trata-se de convocá-la e de ela declarar a que veio.

Diz-se que o sujeito é distância e diferença justamente porque a criança se engancha no discurso do outro e se lança a dizer. Apenas a partir da inscrição histórica ela encontra espaço para falar e pensar em futuro. Em outras palavras, no processo de aprendizagem, o sujeito não constrói o conhecimento, mas, reconstruindo "o conhecimento socialmente compartilhado, reconstrói-se, efetivamente, como sujeito cognoscente, isto é, estrutura-se como sujeito epistêmico" (LAJONQUIÈRE, 1992).

Nesse sentido, cada vez mais os contextos escolares são marcados por adultos que recalcam o passado com o qual estão descontentes e cujo ato não parece sustentar-se por um desejo em nome próprio. Logo, sobram certezas e tentativas fracassadas de realizar um ideal através da criança. Contudo, a possibilidade de que a criança tenha acesso ao seu futuro depende da responsabilização dela e do adulto nesse processo, além da retomada da arbitrariedade do desejo. Destacamos, dessa fala, dois termos: responsabilidade e arbitrariedade, sem os quais não se pode falar em autoria.

Como nosso trabalho se volta para as atividades de reescrita propostas a alunos de, em média, oito anos de idade, o conceito de autoria de Foucault (2001) não se aplica para o estudo ora proposto. Isso porque, para Foucault (2001), a autoria pressupõe instauração de uma "discursividade", isto é, criação de discursos a partir dos quais surjam infinitas possibilidades de novos discursos. É o caso, por exemplo, da obra de Sigmund Freud, cujos 
conceitos e técnicas de análise transcenderam seus próprios escritos e acabaram por fundar uma disciplina nova, a psicanálise, conferindo-lhe reconhecimento e autoridade.

Diferenciar-se do conceito foucaultiano de autoria, contudo, não significa contrapor-se a ele. Assim, mesmo que nossos participantes ainda não sejam, nos termos de Foucault, autores propriamente ditos, pois não fundaram uma discursividade, já parecem evidenciar algum potencial para isso. Trata-se aqui, portanto, de buscar pistas, sinais ou, como postulou Possenti (2002a), “indícios de autoria" em textos que revelam traços de atividade imaginativa.

Interessa-nos, ainda, investigar em que medida, no momento da reescrita, os alunos cometem "erros", rompimentos com o texto previamente lido sem vantagem para a expressão, e em que medida produzem "desvios criativos", subversões dele em proveito da expressão (RIOLFI; BARZOTTO, 2011).

Considerando o aspecto dialógico da linguagem, qualquer texto é, na realidade, resultado de outros textos conhecidos, e sua compreensão é ativamente responsiva (BAKHTIN, 2003). Se a forma como mobilizamos os discursos alheios torna nossa produção única, interessa-nos examinar as maneiras de enunciar de jovens autores, as marcas discursivas que apontam para a sua subjetividade e são, em alguma medida, traços da subversão do modelo escolar de escrita.

Quando nos referimos a atividades de reescrita cujo texto-fonte não está disponível para consulta, inevitavelmente aludimos a, pelo menos, dois tipos de memória: a individual (psicologista), que nesse momento deixaremos em segundo plano, e a discursiva, entendida "nos sentidos entrecruzados da memória mítica, da memória social inscrita em práticas, e da memória construída do historiador" (PÊCHEUX, 1999, p. 49-50).

Observando que todo sujeito está inscrito em um contexto histórico dado antes dele e que o circunscreve, o discurso que ele constrói e o modo como ele interpreta o discurso do outro são localizados social, histórica e discursivamente. Isso porque o dizer não parte de quem o pronuncia, mas "surge de outros discursos, ao mesmo tempo em que aponta para outros" (PÊCHEUX, 1997, p. 77). Os sujeitos inserem-se, portanto, em formações discursivas, a partir das quais constituem seu lugar de fala.

Nesse sentido, a memória discursiva possibilita, em forma de remissões, a repetição. Nas palavras de Pêcheux (1999, p. 52), “a memória discursiva seria aquilo que, face a um texto que surge como acontecimento a ler, vem estabelecer os 'implícitos' (quer dizer, mais tecnicamente, os pré-construídos, elementos citados e relatados, discursos-transversos etc.) de 
que sua leitura necessita [...]”. Em uma relação dialética, o sujeito constitui-se a partir desses elementos e neles age.

$\mathrm{Na}$ prática, qualquer discurso recorre a elementos da memória discursiva social para estimular a construção de sentidos específicos pelo seu receptor. Trata-se do dito no não-dito, daquilo que se encontra na ordem do interdiscurso, do produto do trabalho sobre outros discursos que podem ser modificados, conscientemente ou não, pelo enunciador.

Assim, funcionando como suporte semântico de um discurso, a memória discursiva garante uma regularidade (ou estabilidade) discursiva que, entretanto, é frágil, dada a possibilidade de que um novo acontecimento discursivo, derivado de um acontecimento histórico, invoque enunciados inéditos a partir da desestabilização da fala cotidiana. Por isso, os processos de significação são abertos e sujeitos à incompletude, ao equívoco e, portanto, à interpretação.

No contexto específico deste trabalho, assumindo que a palavra do outro que precede a palavra das crianças é, entre outras, a do autor do texto reescrito, entendemos que ao menos três posições poderiam por elas ser ocupadas no processo de redação do seu texto: ignorar o texto-fonte por escolha ou por incompreensão dele ou da proposta de escrita; decalcar (ainda que com alterações mínimas) o texto-fonte, o que pressupõe plena identificação com ele; e promover uma fala implicada, em que estaria previsto um (pequeno) afastamento do textofonte por parte do aluno que, engendrando-se, pudesse reformulá-lo de modo a dar a ver marcas do interdiscurso ou de seu repertório cultural.

No caso de crianças que, submetidas a um exercício de reescrita, não ignoram o comando de prova, retomamos as três espécies de repetição que, pensadas por Orlandi (1996), poderiam caracterizar o exercício desempenhado pelos alunos. São elas a repetição empírica, a repetição formal e a repetição histórica.

A primeira delas é marcada pelo "exercício mnemônico", em que o indivíduo repete exatamente o que lhe foi endereçado. No domínio de nosso objeto de pesquisa, seria o caso de um ou mais alunos que tivessem conseguido reproduzir, fielmente, parte ou a totalidade do texto-fonte que compunha a sua avaliação.

A segunda delas particulariza-se pelo "exercício gramatical”, em que o indivíduo reproduz o que leu ou ouviu de modo um pouco diferenciado, ou seja, mudando a ordem das frases ou exercendo a sinonímia, por exemplo. Seria o caso dos participantes promotores de deslocamentos e substituições de palavras apenas. 
Finalmente, a terceira pressupõe interpretação. É a repetição histórica que "inscreve o dizer no repetível enquanto memória constitutiva, saber discursivo, em uma palavra: interdiscurso. Este, a memória (rede de filiações), que faz a língua significar” (ORLANDI, 1996, p. 70). Nesse caso, no interior das repetições, o indivíduo formula seu enunciado, isto é, costura, ao texto original, outros discursos que traz à tona. Dessa forma, constitui-se enquanto autor, historicizando seu dizer. Aqui, o aluno exporia seu ponto de vista, revelando imagens e pressuposições, numa espécie de reformulação do texto-fonte.

Portanto, em atividades escolares de reescrita, havendo exemplares de repetição empírica, nos parece que pertencerão a alunos que se comportam como copistas. Por outro lado, havendo exemplares de repetição histórica, nos parece que pertencerão àqueles que tendem a abandonar o processo da pura reprodução para garantir sua condição de sujeito histórico-social (ORLANDI, 1996).

A fim de examinar os trabalhos já publicados a respeito dos temas paráfrase, autoria, escrita e ensino, foi realizada uma busca nas principais plataformas utilizadas para pesquisa acadêmica adotando as seguintes combinações de palavras-chave: paráfrase e escrita; paráfrase e ensino; paráfrase e autoria. Nas publicações entre os anos de 2000 e 2019, identificaram-se três tendências principais:

1) Trabalhos que analisam textos produzidos em outras séries ou níveis de ensino: esses trabalhos examinam manuscritos produzidos como uma demanda da instituição escolar durante o Ensino Fundamental II (RIBEIRO, 2015), o Ensino Médio (RIBEIRO, 2018; SILVA, 2017), a preparação para o vestibular (ALVAREZ, 2018; GONZALES, 2014; MARINHEIRO; BORGES, 2011; MENEGASSI; EMILIANO, 2008) e o Ensino Superior (BEZERRA, 2013; CAMPOS, 2017; DE BORBA; BARRETO; FLÔRES, 2015; PACÍFICO, 2002; PINTO, 2016; RIBEIRO, 2010; SIPAVICIUS SEIDE, 2018; SOUZA, 2010; VAZ, 2008; WILSON; ABREU, 2010). As reformulações parafrásticas surgem, nesses casos, como uma estratégia linguístico-discursiva mobilizada pelos autores.

2) Trabalhos que analisam textos não escolares: os pesquisadores examinam recursos intertextuais utilizados por autores literários renomados, entre eles a paródia, a estilização e a paráfrase (BATISTA; TORGA, 2018; MACHADO, 2006; NEGREIROS, 2009; NASCIMENTO, 2015; PERRONE, 2002; SANTOS, 2012).

3) Trabalhos que propõem modelos pedagógicos: trata-se de pesquisas defensoras de que a autoria, a escrita autônoma e a inserção na cultura letrada possam emergir de atividades que envolvam a paráfrase. Nesse sentido, os pesquisadores apresentam modelos didáticos 
voltados à reformulação do texto do outro (BIASOTTO; CONCEIÇÃO, 2015; GIL, 2002; GUIMARÃES, 2015; MORAES, 2009; NÓBREGA, 2000; REZENDE, 2008).

Nota-se uma ausência de estudos a respeito de paráfrase em contexto escolar, especialmente nos primeiros anos do Ensino Fundamental. Em certa medida, é possível que a presente reflexão venha a diminuí-la.

Além disso, são praticamente inexistentes os trabalhos que se voltam à descrição detalhada dos mecanismos linguístico-discursivos utilizados por crianças quando estão reescrevendo um texto-fonte. Logo, uma reflexão a respeito dos modos como crianças reformulam o que lêem e ouvem no início da escolarização pode fornecer subsídios para aqueles interessados em aquisição da escrita e em seu ensino.

Assim, tomamos como objetivo geral:

Investigar o que ocorre quando crianças do último ano do ciclo de alfabetização (terceiro ano do Ensino Fundamental I) são solicitadas a reescrever textos-fonte, sem consulta, o mais próximo possível do original.

Finalmente, tomando-se as produções de alunos do terceiro ano do Ensino Fundamental I, assumimos como objetivos específicos:

a) Minuciar as operações sistemáticas da escritura utilizadas para reescrever textosfonte;

b) Examinar a presença de autoria em textos que são fruto da reescrita de textos-fonte; e

c) Analisar as especificidades dos textos gerados por diferentes textos-fonte.

A fim de atingir os objetivos definidos para esta pesquisa, dividimos o presente trabalho da seguinte maneira:

No primeiro capítulo, Aprender a escrever no terceiro ano do Ensino Fundamental: um sobrevoo, o contexto onde a pesquisa foi realizada e o método de coleta dos dados serão arrazoados. Conjuntamente, discutiremos de que modo a autoria vinha sendo abordada em documentos oficiais que norteavam o trabalho pedagógico à época da pesquisa.

Por sua vez, no segundo capítulo, Reescrita e autoria no Ensino Fundamental I: duas faces de uma mesma moeda?, a problemática investigada será exposta. Para tanto, 
apresentaremos a concepção de linguagem de que nos valemos. Em seguida, debateremos uma abordagem a respeito de autoria que torne possível observar o fenômeno em textos redigidos por jovens estudantes. Mais tarde, discutiremos um conceito de paráfrase que permita abordar o que ocorre quando crianças reescrevem textos de terceiros.

Já no terceiro capítulo, As operações sistemáticas da escritura, serão descritas as formas de organização e recorte do corpus de pesquisa, bem como de cotejamento entre os manuscritos produzidos pelos participantes e os textos-fonte que lhes serviram de base. Considerada a possibilidade de localizar subsídios para discutir a manifestação da autoria, serão analisadas as operações sistemáticas da escritura (GRÉSILLON; LABRAVE, 1983; GRÉSILLON, 2007) executadas pelos alunos ao longo das atividades. Interessa-nos, ainda, olhar para a recorrência com que algumas transformações são efetuadas pelas crianças. Posteriormente, para ilustrar a dinâmica de reescrita de um texto completo por uma delas, selecionaremos um manuscrito que, a nosso ver, ilustra uma tentativa de expor um ponto de vista por meio da linguagem.

Finalmente, no quarto capítulo, Os textos-fonte e os produtos deles advindos, tendo por objetivo analisar as especificidades das reescritas geradas por diferentes textos-fonte, selecionaremos, para cada uma das quatro atividades avaliativas, três manuscritos completos, a fim de ilustrar algumas tendências observadas durante a análise do corpus.

Por último, seguem as considerações finais deste estudo. 


\section{Aprender a escrever no terceiro ano do Ensino Fundamental: um sobrevoo}

Neste capítulo, cujo objetivo é, em linhas bastante gerais, expor o contexto onde a pesquisa foi realizada, será apresentado como se dá o ensino da Língua Portuguesa em um terceiro ano do Ensino Fundamental de uma escola pública estadual da capital do estado de São Paulo.

\subsection{Bairro e escola}

A pesquisa se deu na Escola de Aplicação da Faculdade de Educação da Universidade de São Paulo (EAUSP), localizada na Cidade Universitária do município de São Paulo, no distrito Butantã (zona oeste).

O bairro, que a leste é delimitado pela margem do Rio Pinheiros, apresenta heterogeneidade socioeconômica. Junto ao rio, há setores de alto padrão. Conforme se distancia do rio, outros bairros de perfil predominantemente residencial surgem acompanhados de áreas comerciais e atravessados por uma rodovia. Vizinho à universidade está o Instituto Butantã e a estação Butantã do metrô (linha 4, amarela), inaugurada em março de 2011.

Porque pertence ao campus da USP na capital, a Escola de Aplicação está rodeada de belas árvores e espaços abertos, tranquilos e limpos. Ademais, além das bibliotecas espalhadas pelas unidades, estão disponíveis à comunidade escolar (alunos, pais, funcionários e professores) o Bilhete USP, que oferece viagens gratuitas nos ônibus do Sistema Circular da CUASO (Cidade Universitária Armando Salles de Oliveira); o Centro de Práticas Esportivas (CEPEUSP); as bolsas de assistência financeira concedidas via avaliação socioeconômica da Superintendência de Assistência Social da USP (SAS-USP); o Hospital Universitário; e os restaurantes universitários (conhecidos como bandejões), onde o preço das refeições, por pessoa, não passa dos $\mathrm{R} \$ 3,00$ (exceto para visitantes).

Quanto ao colégio, segundo o seu regimento escolar, são objetivos da EAUSP:

Sediar e executar pesquisas de interesse próprio ou da Faculdade de Educação, de seus cursos e docentes, que visem ao aperfeiçoamento do processo educativo e de formação docente. 
Oferecer oportunidades de estágio a alunos da Faculdade de Educação e a outras unidades da Universidade de São Paulo.

Oferecer subsídios à Faculdade de Educação da USP ou outras agências públicas de formação do educador.

$>$ Divulgar experiências e contribuições resultantes de suas ações, prioritariamente para a rede pública de ensino.

Assegurar aos educandos a formação comum indispensável para o exercício da cidadania e o usufruto do trabalho oferecendo escolarização regular nos níveis de Ensino Fundamental e de Ensino Médio a filhos e dependentes de professores e funcionários da Universidade de São Paulo, bem como à comunidade externa à Universidade, segundo critérios estabelecidos no Regimento para seleção de alunos. (ESCOLA DE APLICAÇÃO, 2017)

Ainda de acordo com seu regimento, no que concerne à metodologia adotada,

A Escola de Aplicação não se propõe à adoção de um método único de ensino. Procura utilizar diversas estratégias didáticas que favoreçam a compreensão do aluno e seu envolvimento com o conteúdo, o que supõe considerar o educando como sujeito da aprendizagem, sendo essa uma premissa a ser respeitada por todas as disciplinas. Disso decorre a utilização de recursos que mobilizem a curiosidade, o interesse e o engajamento dos estudantes, respeitando as características e as necessidades formativas dos alunos nos diferentes níveis de escolaridade.

Assim, embora seja reconhecida a pertinência das aulas expositivas para determinados conteúdos, os professores procuram não reduzir as situações de ensino e aprendizagem a essa estratégia, buscando a promoção de situações diversificadas. O recurso ao jogo e a atividades lúdicas é visto como valioso instrumento didático. A proposição de situações-problema a serem resolvidas individualmente ou em grupo é outro recurso utilizado. Procura-se, também, promover uma atmosfera de interação positiva por meio do estímulo à cooperação e à solidariedade, inserindo questões para reflexão que tomem por eixo os contextos sócio-históricos do mundo atual.

O corpo docente esforça-se por elaborar atividades que integrem diferentes disciplinas, valorizando a interdisciplinaridade, em um interessante exercício de criação coletiva. São exemplos disso a realização de Estudos do Meio e de Saídas de Estudos, práticas presentes nos diferentes anos escolares, e a realização de outros projetos que impulsionam os estudos, tal como as Oficinas Pedagógicas do Ensino Fundamental I, que serão descritas mais adiante neste Plano Escolar.

O livro didático, adotado em algumas disciplinas, é utilizado como um dentre outros recursos, isto é, apenas como material de apoio ao professor e aos alunos, podendo não ser utilizado inteiramente. Procura-se fazer uma seleção criteriosa para adoção de livros do PNLD e paradidáticos, assim como preservar diante deles a possibilidade de crítica ao seu conteúdo. Além 
dos livros didáticos, são utilizados outros livros e textos de nossa biblioteca e de modo a garantir o acesso a uma diversidade de produções e pontos de vista sobre diferentes temas. (ESCOLA DE APLICAÇÃO, 2017)

Por sua vez, a definição dos objetos de conhecimento prioritários da ação pedagógica na Escola de Aplicação pauta-se nas Diretrizes Curriculares Nacionais para o Ensino Fundamental de Nove Anos, de dezembro de 2010, nas Diretrizes Curriculares Nacionais para o Ensino Médio, de janeiro de 2012, nas Diretrizes Nacionais para a Educação em Direitos Humanos, de maio de 2012, bem como nos Parâmetros e nas Orientações Curriculares Nacionais. Anualmente é reorganizado seu plano escolar.

São objetivos de seu Ensino Fundamental de nove anos:

I - o desenvolvimento da capacidade de aprender, com crescente autonomia e participação nos processos escolares, tendo como meios básicos o pleno domínio da leitura, da escrita e de conhecimentos matemáticos;

II - a compreensão do ambiente natural e social, do sistema político, das artes, da tecnologia, das ciências, das práticas corporais e dos valores em que se fundamenta a vida social;

III - a aquisição de conhecimentos e habilidades, e a formação de atitudes e valores como instrumentos para a participação democrática e para a construção de uma visão crítica do mundo, com destaque para a solidariedade e o respeito mútuos. (UNIVERSIDADE DE SÃO PAULO, 2016, p. 49)

Mais especificamente no Ensino Fundamental I, busca-se:

$>$ o desenvolvimento das crianças e de sua autonomia, respeitando as características etárias e as diferenças individuais, considerando aspectos afetivos, cognitivos, corporais, criativos, estéticos, culturais, de relacionamento interpessoal e de inserção social;

$>$ a alfabetização e o desenvolvimento da proficiência em leitura e escrita em todas as áreas de conhecimento, bem como o desenvolvimento de diversas formas de expressão verbal e não verbal por meio de vivências e de experiências lúdicas, em uma perspectiva articulada dos conteúdos escolares que valorize as experiências e saberes dos educandos. (UNIVERSIDADE DE SÃO PAULO, 2016, p. 49)

Em 2016, ano em que se deu a coleta de dados para a pesquisa, estavam matriculados na escola 724 alunos divididos em 25 turmas, havendo três de $1^{\circ}$ ano do Ensino Fundamental 
e duas dos demais anos escolares (do $2^{\circ}$ ao $9^{\circ}$ ano EF e do $1^{\circ}$ ao $3^{\circ}$ ano EM). Cada turma era formada por no máximo 30 alunos, limite ultrapassado somente em caso de retenção ou trancamento de matrícula.

As 60 vagas abertas, por ano, para o $1^{\circ}$ ano do Ensino Fundamental distribuem-se mediante sorteio público, de acordo com três categorias: 1/3 para filhos de professores e funcionários da FEUSP, 1/3 para filhos de professores e funcionários da USP e 1/3 para a comunidade externa à universidade. As vagas que sobram da primeira categoria, algo comum nos últimos anos, passam para a categoria seguinte. O número total de inscrições para as três categorias é expressivo. Ademais, a cada ano, aproximadamente 1.000 famílias tentam matricular seus filhos na EAFEUSP.

A instituição, além das salas de aula e pátios, tem ambientes de aprendizagem como o laboratório de ciências físicas e biológicas, o laboratório de informática, a biblioteca, o auditório e o complexo de artes, onde são ministradas aulas de música e artes visuais. Há, ainda, uma cozinha, uma horta, uma estufa, um amplo salão destinado às aulas de Educação Física, um parquinho e uma sala de reprografia.

As instâncias de participação e deliberação lá existentes são a Associação de Pais e Mestres, o Grêmio Estudantil e o Conselho de Escola da EAFEUSP. Em 2016, os programas permanentes que aconteciam na escola eram o EAPREVE (Prevenção ao uso de drogas líticas na Escola de Aplicação da USP), o Sexualidade e o Negritude. Especificamente nesse ano, surgiram atividades especiais, como as oficinas no Ensino Fundamental, as disciplinas eletivas para diversas séries e o Projeto Língua Mátria.

Nas aulas de Língua Portuguesa do Ciclo 1 do Ensino Fundamental, ou seja, do $1^{\circ}, 2^{\circ}$ e $3^{\circ}$ anos, que aqui nos interessam, espera-se que o aluno possa:

Experienciar elementos básicos das diferentes linguagens.

- Desenvolver trabalhos relacionados às linguagens (artes visuais, música, teatro, literatura e expressão corporal) de modo que o aluno possa ter contato com múltiplas referências culturais.

$>$ Integrar-se a uma comunidade de leitores, compartilhando diferentes práticas culturais de leitura e de representação.

$>$ Adequar seu discurso às diferentes situações de comunicação oral, considerando o contexto e os interlocutores.

> Participar de situações de intercâmbio oral, ouvindo com atenção, formulando e respondendo perguntas, explicando e ouvindo explicações, manifestando opiniões.

$>$ Promover a socialização, a cooperação e o respeito ao indivíduo, assim como a adoção de atitudes e ações que repudiem qualquer tipo de violência. 
Participar de práticas cotidianas, estabelecendo relações equilibradas e construtivas com os outros, reconhecendo e respeitando a individualidade no que se refere ao desempenho de si próprio e dos outros, sem discriminar características pessoais, físicas, sexuais ou sociais. (UNIVERSIDADE DE SÃO PAULO, 2016, p.69)

Entre todas as práticas mencionadas, podemos dizer que, durante as atividades tomadas como objeto de estudo desta dissertação, as quais consistiram na reescrita fiel e sem consulta, por parte dos alunos, de textos-fonte lidos por sua professora, foi possível que esses tivessem contato com a literatura - ainda que não compartilhando a sua leitura, por estarem em processo de avaliação individual - e, através dela, com algumas práticas culturais, das quais o carnaval é exemplo.

\subsection{Os terceiros anos do Ensino Fundamental}

Os terceiros anos do Ensino Fundamental costumam funcionar em período vespertino, das $14 \mathrm{~h} 00$ às $18 \mathrm{~h} 00$ - sendo o intervalo das $15 \mathrm{~h} 00$ às $15 \mathrm{~h} 30 \mathrm{e}$ os quinze primeiros minutos de aula destinados aos exercícios de relaxamento -, com uma professora polivalente por turma. Contam, ainda, com educadores das disciplinas de Arte, Educação Física, Laboratório e Biblioteca, cujas aulas têm dia da semana e horário fixo para acontecer. Além disso, em 2016, às terças-feiras, das $17 \mathrm{~h} 00$ às $18 \mathrm{~h} 00$, oficinas diversas eram oferecidas a todo o Ensino Fundamental I. Entre uma tarefa e outra, enquanto os colegas terminam a atividade proposta pelo(a) professor(a), os alunos têm o hábito de ler livros e gibis e se distrair com jogos armazenados no fundo da sala, ao lado dos armários com os materiais de cada um.

Consultando o regimento da Escola de Aplicação, percebe-se que a ementa do $3^{\circ}$ ano é constituída de modo a incluir:

Participação em situações de intercâmbio oral, ouvindo com atenção, formulando e respondendo perguntas, explicando e manifestando opiniões sobre o assunto tratado.

> Realização de leitura autônoma de diferentes gêneros textuais (lendas brasileiras, contos de mitologia grega, contos de Andersen, contos de assombração, poesias e ficção fantasiosa).

Realização de recontos coletivos de diferentes gêneros textuais (lendas brasileiras, contos de mitologia grega, contos de Andersen, contos de assombração, poesias e ficção fantasiosa), apropriando-se das características do texto-fonte. 
Estabelecimento de relação entre o gênero, a situação comunicativa e o suporte em que circula originalmente.

$>$ Estabelecimento de relação entre o título e o corpo do texto ou entre as imagens (fotos, ilustrações) e o corpo do texto.

$>$ Domínio das características dos diferentes gêneros textuais (lendas brasileiras, contos de mitologia grega, contos de Andersen, contos de assombração, poesias e ficção fantasiosa).

Realização de produções de textos escritos, coesos e coerentes, dentro dos gêneros trabalhados (lendas brasileiras, contos de mitologia grega, contos de Andersen, contos de assombração, poesias e ficção fantasiosa), ajustados a objetivos e leitores determinados.

> Estabelecimento da sequência temporal de episódios ou procedimentos.

> Revisão do próprio texto a partir de uma primeira versão e produção de novas versões até considerar o texto bem escrito para o momento.

$>$ Domínio da separação de palavras na escrita de um texto e da separação de sílabas no final da linha.

$>$ Domínio de palavras de ortografia regular e de irregularidades mais frequentes na escrita. -Uso do $\mathrm{M}$ antes de $\mathrm{P}$ e B; uso do S e SS; uso do S e Z; uso do R e RR; uso da letra $\mathrm{H}$ (letras que vêm antes $\mathrm{NH}, \mathrm{CH}$ e LH); uso do $\mathrm{CH}$ e X; sons representados pela letra X; uso do L e U; uso do $\mathrm{G}$ e J; uso do C e Ç; uso do HÁ e A; terminação AM e ÃO; terminação OSO e OSA; uso das palavras PORQUE, POR QUE, POR QUÊ e PORQUÊ; uso do MAS e MAIS; uso do MAL e MAU; uso da letra maiúscula no início das frases e nos nomes de pessoas, estados, cidades, países e ruas.

$>$ Utilização de recursos do sistema de pontuação. -Uso do ponto final, ponto de interrogação, ponto de exclamação, vírgula, dois pontos, travessão e reticências.

$>$ Domínio da letra cursiva maiúscula e minúscula. (ESCOLA DE APLICAÇÃO, 2017)

Acrescida a essa ementa, em 2016 a escola declarava a importância da prática da reescrita compreendida no sentido de Bräkling (2013), qual seja, uma atividade de refacção textual "que coloca o foco do aluno na textualização, em si, e não na produção de conteúdo temático" (p. 49).

$\mathrm{Na}$ avaliação das professoras, essa escolha devia-se, em grande parte, à influência de Belintane (2010) e seu projeto $O$ desafio de ensinar a leitura e a escrita no contexto do ensino fundamental de nove anos, acolhido pela instituição, cuja proposta de ensino estaria a serviço da formação de uma matriz textual necessária à leitura e à escrita, das quais a prática pelo aluno que não tem histórias na memória seria prejudicada. Nesse sentido, as atividades do projeto envolviam contação e leitura em voz alta de textos bastante extensos, com o tamanho médio de três páginas. Segundo as pedagogas, justificáveis no âmbito da introjeção do 
registro culto da língua, as principais heranças do programa desenvolvido entre 2011 e 2014 foram as práticas de reescrita das obras lidas em voz alta por elas.

\subsection{Método de coleta dos dados}

Foi realizado estágio de cem horas de observação em escola pública estadual da zona oeste da capital paulista. A investigação foi distribuída ao longo de um ano letivo (entre agosto de 2016 e julho de 2017) e registrada em diário de campo. Após coletados e mediante autorização, os materiais concernidos à pesquisa foram reproduzidos em meios eletrônicos.

\subsubsection{O projeto "Reescrita e manejo da diferença no $3^{\circ}$ ano do Ensino}

\section{Fundamental"}

Em agosto de 2016, no âmbito do projeto coordenado pela Profa. Dra. Claudia Rosa Riolfi Reescrita e manejo da diferença no $3^{\circ}$ ano do Ensino Fundamental, por sua vez inserido no Programa Unificado de Bolsas de Estudos para Estudantes de Graduação (PUB) da Universidade de São Paulo, deu-se o primeiro contato com as professoras regentes das duas turmas de terceiro ano da Escola de Aplicação da Faculdade de Educação da USP, cujas produções escritas constituiriam o corpus desta pesquisa. Pretendia-se, ali, que novas parcerias fossem conquistadas no sentido de contribuírem para a concretização dos objetivos propostos para essa série.

Naquele momento, datas e modus operandi foram definidos, bem como foram feitas a leitura e a discussão do texto do projeto, cujos principais objetivos eram: 1. Colaborar com a formação de futuros professores sensíveis às diferenças intelectuais, linguísticas e culturais presentes em sala de aula; 2. Contribuir para o aprendizado da reescrita pelas crianças matriculadas no terceiro ano do Ensino Fundamental, nos seus diferentes ritmos e demandas; 3. Transformar a sala de aula em uma instância crítica e reflexiva, por meio da exploração das diferenças inerentes à heterogeneidade dentro da sala de aula; e 4. Refletir a respeito de como o ensino deve se organizar para atender demandas coletivas e individualizadas, prevendo processos de aprendizagem e diferentes formas do aprender.

Visando a cumpri-los, determinou-se que as atividades desenvolvidas pelos bolsistas seriam de natureza híbrida, afinal, incluiriam: a) auxílio à prática docente; b) intervenção pedagógica; c) pesquisa acadêmica junto aos pesquisadores do Grupo de Estudos e Pesquisa 
Produção Escrita e Psicanálise da Faculdade de Educação da USP - GEPPEP (cujas informações estão disponíveis em http://paje.fe.usp.br/ geppep/); e d) divulgação científica por meio de publicação de artigo em revista especializada.

Foi pactuado, ainda, que os resultados dessa empreitada seriam disseminados, mesmo após o término do programa, nas seguintes instâncias: a) $25^{\circ}$ Simpósio Internacional de Iniciação Científica e Tecnológica da USP (SIICUSP); b) XIII Workshop Produção Escrita e Psicanálise; e c) XVI Seminário de Metodologia de Ensino de Língua Portuguesa.

Ao longo do ano, as principais atividades rotineiramente desenvolvidas foram: a) acompanhamento das turmas, de modo a garantir o vínculo com as crianças das classes; b) atendimento às crianças com dificuldade de leitura, interpretação, produção e revisão de texto; c) digitalização das versões de textos produzidas pelos alunos; d) análise das mesmas, de modo a poder realizar interferências individualizadas aos estudantes, favorecendo uma aprendizagem sensível às diferenças; e) elaboração de diferentes avaliações; f) auxílio na produção de material didático contextualizado no cotidiano das crianças; g) participação nas reuniões do GEPPEP; h) leituras concernentes; i) encontros com a orientadora para estabelecimento de novos encaminhamentos; j) alimentação do banco de dados do GEPPEP com os textos produzidos pelas crianças; k) seleção de jogos virtuais para uso com as turmas; 1) produção de jogos artesanais como memória, dominó, bingo e mico ortográficos; e m) organização de oficinas.

Por meio das intervenções pedagógicas promovidas, muitas vezes, de modo personalizado, o projeto colaborou para o melhor domínio da modalidade escrita da Língua Portuguesa por parte dos estudantes, instigando neles a prática de relerem suas próprias produções e explorando suas diferenças em vez de escamoteá-las. Pareceu contribuir, ainda, para que as professoras seguissem o plano de aula com mais tranquilidade, à medida que dúvidas pontuais eram sanadas durante atendimentos individuais às crianças. Considerando a heterogeneidade de aprendizagens, procurou-se garantir espaço para a diversidade coadunado às preocupações ligadas ao rigor da escrita.

A mim, o programa proporcionou: a) uma formação acadêmica mais apoiada na prática educativa; e b) uma percepção das várias maneiras como discursos específicos são constituídos, reproduzidos, ressignificados e, muitas vezes, contestados em sala de aula.

A pesquisa realizada junto ao $P U B$, mais tarde ampliada em nível de Iniciação Científica e inserida no projeto coletivo Leituras Errantes do GEPPEP, desdobrou-se no 
projeto deste mestrado, que parte da análise de 236 manuscritos produzidos por alunos assistidos durante o programa.

\subsubsection{A autoria nos documentos relacionados à pesquisa}

A fim de esclarecer de que modo a autoria vinha sendo abordada em documentos oficiais que norteavam o trabalho pedagógico à época da pesquisa, cumpre dizer que o Governo do Estado de São Paulo orientava os professores a considerar tanto a reescrita de textos quanto a produção de autoria atividades fundamentais no desenvolvimento do trabalho de produção escrita (BRÄKLING, 2013). Para esse documento, o que diferencia as duas tarefas é o tipo de conhecimento que requerem que os alunos mobilizem. Segundo Bräkling (2013), no processo de produção de textos, cinco seriam as operações fundamentais:

1. Contextualização, que consiste em recuperar o contexto de produção definido para o texto, tornando-o coerente com a situação comunicativa;

2. Elaboração e tratamento do conteúdo temático, que consiste em levantar informações, definir posicionamentos e/ou criar a trama, dependendo do gênero textual a ser praticado;

3. Planificação, que consiste em definir quais serão as partes do texto e de que maneira estarão articuladas;

4. Textualização, que consiste em produzir o texto em si; e

5. Revisão, que consiste em reler e ajustar o texto produzido.

No caso da produção de autoria, em que o texto redigido pelo aluno é original tanto no que se refere ao conteúdo temático quanto no que tange ao texto em si, vários aspectos devem ser definidos:

a) o contexto de produção;

b) o tema que será tratado (o que depende do gênero do texto que se produzirá);

c) a maneira pela qual será tratado esse tema - se com humor, seriedade, sarcasmo, ironia, leveza, poeticidade, literariedade, dramaticidade, suspense, por exemplo;

d) o tipo de narrador e a perspectiva da qual o tema será tratado, caso seja um texto literário;

e) os episódios, fatos e acontecimentos que constituirão o texto, de que modo serão articulados e em torno de qual eixo serão organizados (de 
temporalidade - com ou sem estabelecimento necessário de relações de causalidade -, de relevância, por exemplo);

f) o registro linguístico a ser utilizado (literário, acadêmico, formalinstitucional, legal/jurídico, jornalístico, pessoal, informal mas não íntimo, pessoal e íntimo, informal com gíria específica, entre outros);

g) o estilo do texto (se bastante descritivo ou não, por exemplo);

h) a textualização, em si, com todos os aspectos que envolve, fundamentalmente a manutenção da coerência e o estabelecimento de coesão, selecionando mecanismos e recursos textuais adequados às relações que se desejar estabelecer entre os trechos do texto. (BRÄKLING, 2013, p. 53)

No caso da reescrita, por outro lado, o foco do aluno não está na produção de conteúdo temático, mas na textualização. Isso porque ele já conhece o texto e sua tarefa é recontar por escrito o conteúdo sabido. No manual, a importância dos exercícios de reescrita justifica-se da seguinte maneira:

1. Porque é possível aprender sobre linguagem escrita antes de saber grafar a linguagem (organização interna dos textos; recursos de linguagem literária; características da linguagem escrita como um todo).

2. Porque essa é uma atividade que permite que o foco do trabalho do aluno seja no processo de textualização, uma vez que o conteúdo - assunto, tema - do texto já está definido. O aluno, nesse caso, não precisa produzir - criar ou pesquisar - o conteúdo temático, concentrando seus esforços em redigir o texto, em organizar o enunciado. Além disso, deixa o aluno mais livre para prestar atenção em recursos linguísticos e discursivos utilizados no texto fonte, criando a possibilidade de apropriação dos mesmos e utilização no texto pessoal.

3. Para modelizar procedimentos de textualização - quando a atividade for realizada coletivamente como ditado ao professor.

4. Para possibilitar ao aluno a prática dos procedimentos de textualização, como: a planificação do texto; a utilização dessa planificação como orientadora da textualização; a revisão processual do texto (analisar parte a parte o que foi escrito, verificando as articulações realizadas, a manutenção da coerência e a adequação dos articuladores); a revisão posterior do texto (análise global da primeira versão do texto, verificando sua correção gramatical e sua adequação discursiva, assim como a pertinência dos articuladores e das decorrentes relações criadas pelos mesmos no texto).

5. Porque é possível coordenar os diferentes procedimentos escritores, progressivamente, quando articulados às diferentes maneiras de se planejar essa atividade.

6. Porque é possível que o aluno exerça diferentes papéis enunciativos quando a atividade é realizada em duplas ou trios, o que é fundamental na atividade de escrita, pois tais papéis a constituem. (BRÄKLING, 2013, p. 49-50) 
Em resumo, na reescrita, é preciso que se considere a organização dos fatos e as relações estabelecidas no texto original, mas, ainda assim, trata-se de atividade menos complexa, segundo o documento, e facilitadora da introjeção do registro escrito da língua. Por isso, inclusive, nas escolas que seguem as orientações fornecidas pelo governo estadual, a reescrita de textos ficcionais da esfera literária previamente lidos é atividade estimulada nos primeiros anos do Ensino Fundamental.

De acordo com a visão apresentada, as atividades de reescrita sanam, antecipadamente, os obstáculos que os alunos, nas séries mais avançadas, tendem a enfrentar ao escreverem seus próprios textos. Durante sua realização, espera-se que as crianças sejam colocadas em contato com o bloco de conhecimentos supostamente necessários à criação de uma boa produção.

Assim, em escolas que, nos anos iniciais do Ensino Fundamental, acolhem tais orientações, o que se estimula é a retração da autoria em favor de um texto convencionado, cujo fim é a avaliação, e do exercício de um único padrão de língua. Em outras palavras, estimula-se a produção de "redações" (GERALDI, 1985).

Nas demais escolas e níveis de ensino, vários são os usos da reescrita. Ora ela aparece associada ao melhoramento dos próprios textos (FIAD, 2009; GUSSO; DALLA-BONA, 2014), ora é utilizada para conotar o exercício didático de solicitar a crianças em fase de aquisição da linguagem que reescrevam textos redigidos por terceiros (CAMPOS, 2008; FLÔRES, 2014; NÓBREGA, 2011; SANTOS; CAVALCANTE; LIRA, 2015), ora está relacionada à apropriação, por parte de quem escreve, de fragmentos grafados por outrem (MARINHEIRO; BORGES, 2011).

Os autores mencionados, que estudaram o tipo de atividade que aqui nos interessa, isto é, de reescrita de textos de terceiros, concluíram que, como sugerem as orientações oficiais, ele pode ampliar a consciência textual dos estudantes, embora tenham reconhecido que: a) nesses exercícios, o leitor inevitavelmente filtra a obra de referência com base em experiências extratextuais, ou seja, adapta a história de modo a torná-la mais significativa para si, reproduzindo-a ativamente; b) atividades que não incentivam a transformação do sujeitoaluno em sujeito-autor levam a enunciados previsíveis, que não extrapolam o lugar comum; e c) somente textos autorais revelam o verdadeiro estágio de desenvolvimento do aluno, afinal, o número de falhas ortográficas, por exemplo, é significativamente maior nesse tipo complexo de produção. 
Nossa pesquisa, que partilha do posicionamento de tais autores frente às orientações do governo do estado, analisa alguns dos meandros do que ocorre quando exercícios dessa natureza são aplicados.

\subsubsection{Os participantes da pesquisa}

Foram acompanhadas quatro turmas vespertinas de terceiro ano do Ensino Fundamental I, duas durante o segundo semestre de 2016 e duas durante o primeiro semestre de 2017. A composição delas está descrita a seguir:

\section{6}

$3^{\circ}$ ano I: quinze meninas; quinze meninos.

$3^{\circ}$ ano II: catorze meninas; dezesseis meninos.

\section{7}

$3^{\circ}$ ano I: dezesseis meninas; catorze meninos.

$3^{\circ}$ ano II: quinze meninas; quinze meninos.

A facilidade de acesso aos textos digitalizados dos $3^{\text {os }}$ anos I e II de 2016 levou-nos a selecionar, para análise, as produções dessas turmas. Cada uma era composta por trinta alunos cursando o terceiro ano do Ensino Fundamental no período vespertino. Entretanto, em uma delas ( $3^{\circ}$ ano II), havia um estudante com diagnóstico inicial de autismo que não estava alfabetizado e nem costumava participar das atividades. Por esse motivo, a pesquisa voltou-se para a análise de textos produzidos por cinquenta e nove crianças.

O grupo de alunos era composto por vinte e oito meninas e trinta e um meninos, em sua maioria com idade de oito anos e pertencentes à classe média-baixa, de acordo com levantamento feito pela própria escola. Mediante comprovação de renda dos responsáveis, a escola fornecia lanche, ingresso para os estudos do meio e todo o material necessário ao bom rendimento escolar (incluindo o de uso pessoal) para alunos considerados carentes.

Com relação ao processo de aprendizagem, tratava-se de um grupo relativamente homogêneo. Nessa escola e série, os resultados obtidos pelos alunos nas avaliações de cada disciplina não eram compostos por algarismos, mas por conceitos. Eram eles: não satisfatório, 
satisfatório e plenamente satisfatório. Praticamente não existiam atribuições, por parte das professoras, de conceito "insatisfatório" nessas turmas.

Ademais, não havia grandes disparidades entre os alunos no que concernia à realização dos exercícios didáticos propostos pelas duas professoras polivalentes, que estavam bastante alinhadas quanto às atividades aplicadas e adotavam materiais idênticos, muitas vezes preparados por elas.

A maior parte das dificuldades que as crianças apresentavam estava ligada à caligrafia, à disciplina, à adaptação ao tempo estipulado para cada tarefa e ao respeitar o comando de avaliação.Muitos alunos insistiam em criar novos personagens quando a atividade exigia que um dado texto fosse apenas reescrito, por exemplo. Dificuldades relativas à alfabetização e à apreensão de conceitos eram raras, portanto.

\subsubsection{Descrição do corpus}

Nosso corpus é composto por 236 produções de cinquenta e nove alunos, frutos das avaliações trimestrais rotineiramente aplicadas na escola em 2016. Para instruir a pesquisa, os materiais, comandos de prova e instruções verbais também foram coletados. Termos de autorização para uso das produções em contexto de pesquisa foram elaborados, distribuídos aos alunos e, uma vez assinados por seus pais, recolhidos.

Ao longo do ano, as crianças eram expostas, aproximadamente a cada três semanas, ao mesmo tipo de exercício, que consistia em ler um texto (às vezes individualmente, às vezes coletivamente), responder algumas questões dissertativas referentes a ele e, quase sempre após a (segunda) leitura em voz alta da professora, reescrevê-lo do modo mais fiel possível ao original. Normalmente, o texto lido era composto de, em média, três páginas.

A professora costumava distribuir folhas com o texto e as perguntas referentes a ele. Lia cerca de três quartos do texto em voz alta enquanto as crianças a acompanhavam. Então, pedia para que continuassem sozinhas e silenciosamente. Nesses momentos, muitas se perdiam e pediam ajuda, alegando que a professora lia muito rápido e que não reconheciam em que lugar do texto ela estava. Depois que a professora julgava que os alunos tinham se localizado, as questões eram resolvidas com consulta ao texto e, tendo quase todos terminado, corrigidas na lousa. Só então a professora, que muitas vezes relia o texto para a turma, solicitava sua reescrita, durante a qual as crianças eram proibidas de consultá-lo. 
O mesmo tipo de exercício era utilizado por ocasião das avaliações trimestrais com pequenas alterações: 1) O texto dado a ler costumava ser ligeiramente mais curto do que os utilizados nos exercícios; 2) A professora não corrigia a lição de interpretação de texto em voz alta imediatamente antes da solicitação da reescrita; e 3) A discussão oral a respeito da sequência dos fatos da narrativa não era realizada. Em vez disso, para orientar os alunos, eralhes fornecida uma sequência de imagens representativas dos eventos principais da história. A figura 1, a seguir, exemplifica esse tipo de apoio.

Figura1: Imagens norteadoras para a reescrita do texto "A rainha da bateria"
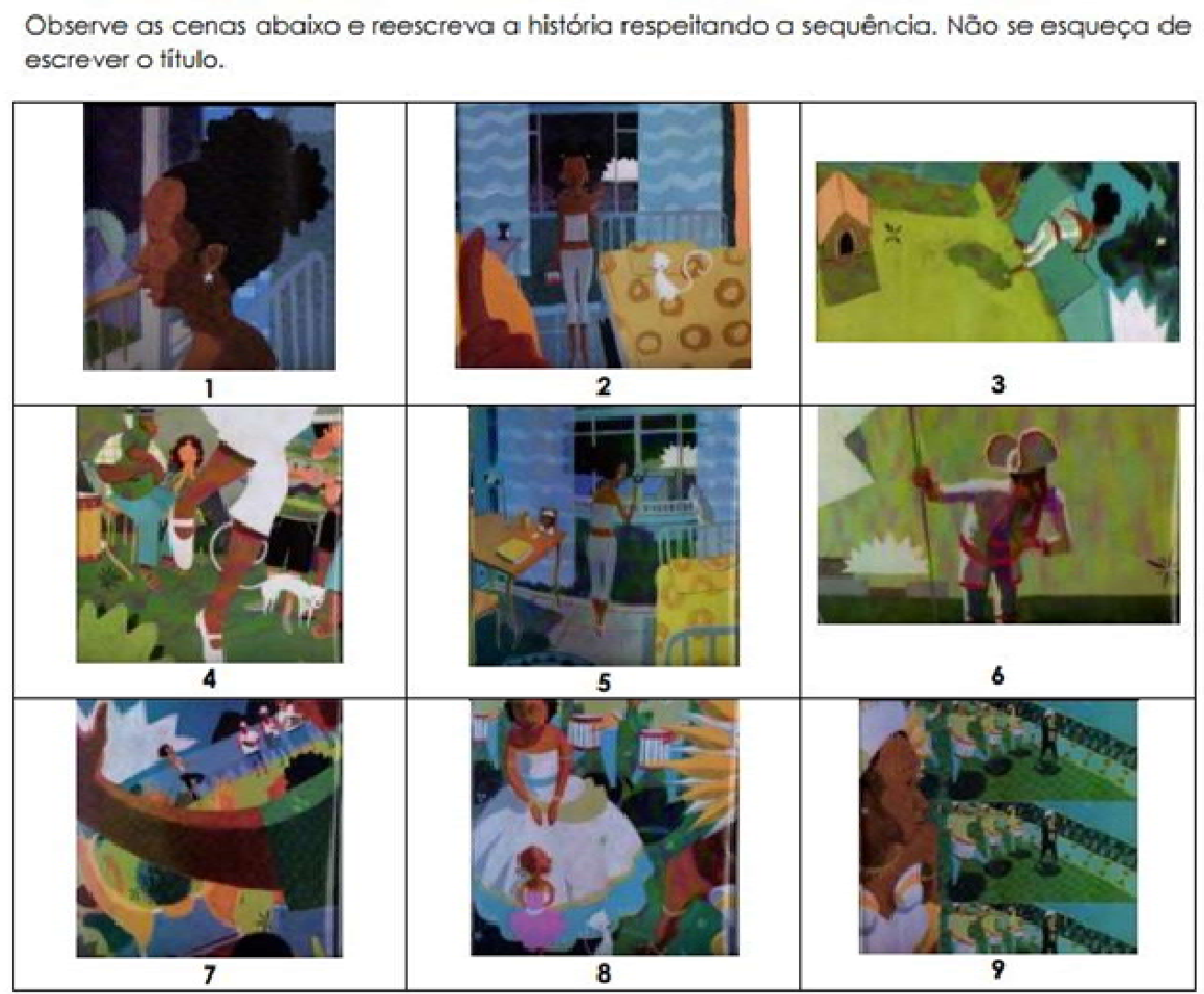

Fonte: VILA (2009)

A imagem reproduzida na figura 1 é composta por nove imagens numeradas. Acima da primeira imagem, pode-se ler a seguinte instrução: "Observe as cenas abaixo e reescreva a história respeitando a sequência. Não se esqueça de escrever o título".

Retirada do livro homônimo ao conto, escrito por Martinho da Vila, ilustrado por Marcelo D’Salete e publicado pela Editora Lazuli Infantil em 2009, a sequência de imagens servia de apoio aos alunos no momento da reescrita do texto à medida que recuperava a ordem dos acontecimentos da história. Se nas imagens 1 e 2 a protagonista apenas observa a 
escola de samba da janela aberta de seu quarto, desejando frequentá-la, na imagem 3 ela já se arrisca a ir escondida para lá. Tendo se divertido muito (imagem 4), mas sendo pega pela mãe, é trancafiada em seu quarto, tornando-se uma menina bastante triste (imagem 5). Algum tempo depois, conhece Silas (imagem 6) e pode, enfim, voltar a sambar (imagem 7). Com ele casa-se, tem uma filha (imagem 8), ocupa o posto de rainha da bateria e, vencido o preconceito da mãe, vê sua família reunida desfilando no carnaval (imagem 9).

Esse tipo de exercício de reescrita foi solicitado às crianças nas quatro avaliações trimestrais analisadas ao longo da realização desta pesquisa, as quais detalhamos a seguir.

Fevereiro: Aplicada no início do ano letivo, essa avaliação teve caráter diagnóstico. $\mathrm{O}$ exercício foi montado pela professora regente a partir do texto-fonte intitulado "A rainha da bateria", escrito por Martinho da Vila. Em termos gerais, o texto-fonte conta a história de Maria Luisa, uma jovem órfã de pai que foi proibida por uma mãe preconceituosa de frequentar a escola de samba localizada perto de sua residência. Após uma adolescência de sofrimento e de reclusão, a jovem casa-se com um antigo colega, tem com ele uma filha e torna-se rainha da bateria de uma grande escola de samba. O objetivo dessa primeira avaliação vinha registrado no topo da folha entregue aos estudantes. A proposta era verificar se os alunos, no momento da reescrita, eram capazes de escrever o título da história, respeitar a sequência dos acontecimentos, organizar as ideias nas frases de maneira clara e coerente, produzir um texto com coesão, colocar o ponto final no fim das frases, redigir corretamente as palavras de uso comum e apresentar letra legível.

Abril: O exercício foi montado pela professora regente a partir do texto-fonte "Joãode-barro", lenda retirada do site Sóhistória (2019). Em termos gerais, o texto-fonte narra a origem mítica do pássaro João-de-barro. Jaebé, moço de uma tribo do sul do Brasil, apaixonase pela moça mais formosa de sua tribo e submete-se ao desafio de sobreviver a um jejum de nove dias para dar provas da força de seu amor. Quando abrem o couro onde está enrolado o jovem, ele transforma-se no pássaro. Como o mesmo ocorre com sua amada, ambos partem para a floresta, onde constroem sua casa de barro. Além dos objetivos já mencionados na avaliação de fevereiro, expectativas com relação à diagramação dos parágrafos, colocação de letra maiúscula no início de frases e adoção de travessões e pontos de interrogação e exclamação foram acrescidas.

Agosto: O exercício foi montado pela professora regente a partir do texto-fonte "Maria Angula (Equador)" (Uribe, 1999). Em termos gerais, o texto-fonte narra a desventura da jovem Maria Angula que, por ser muito prepotente, acaba sendo vítima da vingança de sua 
vizinha. A fim de agradar seu marido, Maria frequentemente procura sua vizinha para que ela lhe dê conselhos culinários. No entanto, nunca reconhece a ajuda recebida. Descontente, a moça sugere que Maria roube o estômago de um morto caso queira preparar um caldo de tripas maravilhoso para o companheiro. Tendo ouvido a colega, Maria Angula é assombrada durante uma noite inteira pelo defunto violado e, depois disso, nunca mais é vista. Dessa vez, os critérios de avaliação mantiveram-se os mesmos da tarefa anterior.

Novembro: O exercício foi montado pela professora regente a partir do texto-fonte "Uma festa muito esperada" (TOLKIEN, 2001). Trata-se de uma adaptação do primeiro capítulo do primeiro volume da trilogia O Senhor dos Anéis (composto por A Sociedade do Anel, As Duas Torres e O Retorno do Rei) (TOLKIEN, 2001). Em termos gerais, o textofonte narra o dia de um evento promovido por Bilbo Bolseiro, herói de O Hobbit (TOLKIEN, 2013) que, tendo voltado de sua jornada há sessenta anos, é reconhecido por sua riqueza e por não envelhecer. Em comemoração ao seu $111^{\circ}$ aniversário, ele anuncia uma grande festa ao lado de seu primo Frodo, que vive com ele e é escolhido como seu herdeiro. Nessa ocasião, Bilbo anuncia que irá embora do Condado e, após breve discurso, coloca seu anel mágico e desaparece, causando algum alvoroço. Após longa conversa com o mago Gandalf, seu companheiro de aventuras, decide deixar o anel com Frodo - que por sua vez é aconselhado a não vestir a joia -, e parte. Novamente, os critérios de avaliação mantiveram-se os mesmos dos dois últimos exercícios.

Os alunos tinham, em média, o período de quatro horas para completarem cada avaliação. Nas avaliações de fevereiro, os textos produzidos pelos alunos tinham cerca de oitenta linhas de caderno manuscritas. Com o passar do tempo, chegaram a ocupar mais de cento e vinte delas. Outra mudança visível é relativa à divisão do texto em parágrafos. No início, eram comuns as narrativas compostas por apenas um parágrafo e nenhum recuo. A partir de agosto, metade deles, aproximadamente, já dividia o texto em parágrafos de modo autônomo. Ao longo do tempo, os erros de ortografia foram diminuindo, e o uso de letra cursiva firmando-se. 


\section{Reescrita e autoria no Ensino Fundamental I: duas faces de uma mesma moeda?}

Neste capítulo, cujo objetivo é discutir a problemática a ser investigada, apresentaremos, primeiramente, a concepção de linguagem de que nos valemos. Em seguida, debateremos uma abordagem a respeito de autoria que torne possível observar o fenômeno em textos redigidos por jovens estudantes. Posteriormente, discutiremos um conceito de paráfrase que permita abordar o que ocorre quando crianças reescrevem textos de terceiros.

Dado que esta pesquisa toma como objeto de estudo textos redigidos por crianças em situação de avaliação bimestral, convém assinalar que a relevância desse contexto está, entre outros, no fato de que, durante as avaliações, "as respostas que os alunos nos dão fornecem informações sobre como eles pensam e aprendem, e também como compreendem as perguntas que lhes fazemos" (SUASSUNA, 2007, p. 113). Esse esforço justifica-se uma vez que a meta de promover a melhoria na qualidade da educação básica passa pela necessidade de aproximação entre as políticas públicas, a legislação educacional, a pesquisa acadêmica e a realidade estudantil.

Deve-se considerar o efeito dos instrumentos avaliativos sobre as formulações que os aprendizes revelam, entretanto, é interessante não tomar como absolutas ponderações como aquelas que textos semelhantes ao de Suassuna (2007) deixam entrever. Ao discutir instrumentos de avaliação, a autora defende a utilização de propostas de produção de texto escrito que levem o aluno a, em suas palavras, "expressar sua visão de mundo" (SUASSUNA, 2007 , p. 125). Essa afirmação leva a crer que haveria propostas em que os alunos não a expressam. Uma atividade de reescrita de texto de terceiros provavelmente seria classificada nessa última vertente. $\mathrm{O}$ que a presente investigação pretende verificar é se, de fato, nesse tipo de atividade, o modo como os participantes posicionam-se frente ao mundo não se deposita no texto reescrito.

\subsection{Nossa concepção de linguagem}

Ao longo do presente estudo, a linguagem é, em primeiro lugar, concebida como constitutiva do sujeito. Para Benveniste (1991), a passagem de locutor (indivíduo falante) para sujeito se dá quando o locutor, apresentando-se, faz menção a si mesmo como "eu". Tomar consciência desse processo depende, contudo, de que o "eu" instaure um "tu" a quem se 
dirige. Assim, na visão do autor, a subjetividade - que é a capacidade do locutor propor-se como sujeito - tem fundamento linguístico.

A linguagem, em contrapartida, é um campo heterogêneo que articula língua (fato) e fala (ato), estrutura e sujeito. Por isso, é não transparente, ou seja, fonte de equívocos, passível de uma infinidade de sentidos. Ademais, é entendida como dialógica, o que significa dizer que, nas práticas linguageiras, infinitas relações com discursos alheios, nem sempre aparentes, são estabelecidas. Devido a esse caráter polissêmico e plurívoco, a linguagem escapa à intenção daquele que fala e instaura a subjetividade (BENVENISTE, 1991).

Portanto, não fosse seu caráter constitutivo, nada haveria de permanente na linguagem. Embora a estrutura dessa atividade seja relativamente estável, concordamos com Franchi (1992, p. 31) sobre não podermos considerá-la como "dado ou resultado", mas como "um trabalho que 'dá forma' ao conteúdo variável de nossas experiências”. Trata-se de, através da linguagem, construir um "sistema de referências" que permita dar significado àquilo que foi vivido. Esse trabalho, contudo, é coletivo. Nele, cada um pode tanto se identificar com os pares quanto a eles se contrapor.

Uma vez concebida como trabalho, a linguagem é elemento ontológico fundador do ser humano, mais complexo do que a simples emissão vocal instintiva dos animais (ROSSILANDI, 1985). É trabalhando e falando que o homem constitui-se social e historicamente. Diferencia-se, portanto, do animal não somente por produzir ferramentas de trabalho, mas também por produzir enunciados.

Por encarar a linguagem como trabalho linguístico, Rossi-Landi (1985) propõe que se diferenciem: a) textos providos de funcionalidade social, frutos de trabalho linguístico e munidos de um valor de uso (em que o sentido é priorizado); de b) textos marcados pela reprodução, munidos apenas de um valor de troca, o que os torna simples produtos valorados pelo mercado linguístico.

No contexto específico deste estudo, em que analisamos produções de alunos solicitados a reescrever textos lidos, acreditamos na possibilidade de que, ao restaurá-los, as crianças encontrem margem para efetuar um trabalho linguístico.

Isso porque, dada a polissemia da linguagem (BENVENISTE, 1991), nada nem ninguém garante o que será compreendido daquilo que foi lido e, consequentemente, prevê o que será reescrito. Assim, frente à possibilidade de afastarem-se da mera repetição, os alunos podem vir a produzir textos não só providos de um valor de troca, como também de um valor de uso. 
Posto isso, estamos em condição de passar a expor alguns desdobramentos pedagógicos advindos da concepção de linguagem escolhida por nós. Por reconhecer a opacidade da linguagem e seu consequente caráter enigmático, tal concepção implica que o equívoco seja encarado como revelador do processo de construção do conhecimento em sala de aula, o que oportuniza a inclusão da palavra do aluno nesse contexto.

Assim, embora as concepções tecnicistas estejam bastante presentes na formação do professor atual, parece razoável que ele esteja autorizado a arriscar-se em sala de aula sem que, em um movimento de "adiamento da prática docente" (FAIRCHILD, 2009), sua postura soe como permissiva, negligente ou despreparada.

Quando o exercício da língua se dá estritamente ligado à técnica, o professor torna-se transmissor de um repertório de saberes congelados e passa a apostar na possibilidade de que, durante o ensino, tudo possa ser previsto.

Com isso, não se pretende afirmar que dispensável é o conhecimento de certo cabedal teórico, porém mais importante parece dar consequência ao discurso do aluno, até mesmo quando ele erra, e mostrá-lo que, sem o estar avaliando, há quem o escute e reconheça seus movimentos de linguagem (FAIRCHILD, 2009).

Sintomas contrários, entretanto, vêm sendo observados por autores como Fairchild (2009), para quem é preocupante "a evitação da palavra do outro, seja na forma do aluno que evita o texto e encontra maneiras de, lendo-o, não o ler; seja na forma do professor que evita a discursividade do aluno, ancorando-se na segurança de um normativismo dogmático" (FAIRCHILD, 2009, p. 506).

Na prática, as atividades de produção de texto propostas em contexto de ensino são reveladoras da concepção de linguagem que prevalece na escola (PIETRI, 2010). Por exemplo, nos casos em que se apresenta um tema ao aluno para que ele preencha, durante intervalo de tempo predefinido, um número de linhas, seguindo moldes de um gênero préselecionado que, muitas vezes, só circula ou é praticado naquele ambiente, a linguagem deixa de ter função comunicativa, isto é, deixa de estabelecer relação com uma situação de comunicação verdadeira.

Por sua vez, quando a tarefa pressupõe a simples reiteração do que foi lido, corre-se o risco de que sejam desconsideradas as condições de produção do texto (seus objetivos, suas funções, o perfil de seus destinatários, o contexto social de sua circulação, seu veículo ou suporte, suas possibilidades de variedade e registro, as convenções linguístico-discursivas que respeita, entre outras). Nesse caso, o texto lido serve apenas como fonte de cópia e o texto 
reescrito torna-se mera somatória de frases, não concebido como fruto da interação entre os sujeitos. Assim, “a leitura não é vista como parte do processo de escrita, o que apaga a existência de processos intertextuais e torna a atuação sobre o texto algo restrito a atividades de revisão formal de sua superfície" (PIETRI, 2010, p. 136).

Dessas práticas homogeneizantes, a consequência é a produção de um texto bom em termos formais, ou seja, que não apresenta problemas ortográficos ou gramaticais, mas que nada tem a dizer e não evidencia "a existência de um sujeito responsável pelo enunciado" que não somente "reproduz o senso comum" (PIETRI, 2010, p. 144). Em outras palavras, os exercícios de reescrita que não estão vinculados à habilidade de reler-se criticamente e à promoção da heterogeneidade, mas à imitação do cânone, acionam nos alunos uma sensação de "resposta certa a ser dada" que acaba por produzir repetições congeladas muitas vezes alinhadas com a própria expectativa docente.

Nesse sentido, se retomarmos a concepção de linguagem de que nos valemos, segundo a qual, durante o seu uso, não se pode apreender tudo o que está em jogo, temos a tensão para a qual voltamos nosso interesse: aquela entre a expectativa institucional de reprodução parafrástica e a meta de ensino a longo prazo, a do ciclo autoral.

\subsection{O conceito operacional de autoria com o qual trabalhamos}

Para construir um conceito operacional de autoria que nos ajude a observar o fenômeno em textos redigidos por jovens estudantes, mobilizaremos alguns estudos que versam a respeito das seguintes temáticas: a autoria enquanto indício (POSSENTI, 2002a; 2013), a autoria enquanto posicionamento subjetivo (RIOLFI; MAGALHÃES, 2008) e a autoria enquanto estilo (COSTA, 2016; 2019).

\subsubsection{A autoria enquanto indício}

Para Foucault (2001), a autoria está ligada ao advento de um nome de autor. Diferentemente do nome próprio comum, aquele funciona para caracterizar certo modo de discurso que ganha status em uma dada cultura pela ruptura que instaura na palavra cotidiana. De acordo com Foucault (2001), o que caracteriza a autoria é a capacidade de remanejar um campo epistemológico ou discursivo de modo a criar um novo plano que transforma radicalmente o anterior. 
O produto desse remanejamento, se não for considerado novo, ao menos apresenta novidades, haja vista os modos de articulação da heterogeneidade da linguagem. Nesse sentido, os discursos providos da função-autor: a) seriam, inicialmente, objetos de apropriação; b) não poderiam ser atribuídos ao seu produtor de forma espontânea, mas por operações específicas e complexas; c) não existiriam sem obra, sabendo-se que toda obra só existe quando publicada e/ou reconhecida por um grupo de pessoas; e d) estariam assinados por alguém que assume a responsabilidade pelo enunciado, gozando de certos privilégios e tendo direitos sobre seu trabalho (FOUCAULT, 2001).

Como nosso trabalho volta-se para as atividades de reescrita por crianças de, em média, 8 anos de idade, o conceito de autoria de Foucault (2001) não se aplica para o estudo ora proposto. Isso não significa que buscar estudar autoria em textos de crianças seja impossível. Embora jovens em idade escolar ainda não sejam autores propriamente ditos, já parecem evidenciar algum potencial para instaurar rupturas com a palavra cotidiana.

Trata-se aqui, portanto, de buscar pistas ou sinais de autoria. É dessa possibilidade que Possenti (2013) ocupa-se em texto no qual, dialogando com o trabalho de Foucault, advoga a favor da existência de traços de autoria, compreendida como um efeito simultâneo de um jogo estilístico e de uma posição enunciativa, em contexto escolar.

Levando o trabalho de Foucault em conta, Possenti (2002a; 2013) postula que, quando se trata de investigar autoria em textos de crianças que, muito cedo, revelam traços de atividade imaginativa e comportam-se como potenciais escritores criativos, o caminho mais vantajoso é o de localizar "indícios de autoria". O autor forjou essa expressão a partir do “paradigma indiciário"(GINZBURG, 1986), método interpretativo voltado aos "resíduos”, aos "dados marginais, considerados reveladores" (p. 149) e capazes de "remontar a uma realidade complexa não experimentável diretamente", embora "aparentemente negligenciáveis" (GINZBURG, 1986, p. 152).

Do ponto de vista de Possenti (2002a), torna-se autor aquele que, conscientemente ou não, dá voz a outros enunciadores e mantém distância em relação ao próprio texto. Nesse sentido, o texto autoral depende do modo como o autor dá voz aos outros, expondo-se e retirando-se de cena sutilmente, abrindo espaço ao leitor: "tem mais a ver com como do que com o quê" (POSSENTI, 2002a, p. 106). Em suma, quando diversos recursos da língua são mobilizados "pessoalmente" e a partir de "condicionamentos históricos", há autoria.

Concordando com a lógica do autor, a análise de um texto não pode se basear apenas em categorias gramaticais e textuais, mas também em termos discursivos. Não se tem como 
conjecturar a respeito dos indícios de autoria em textos de crianças sem considerar a subjetividade e a inserção do texto em um quadro histórico que lhe dê sentido. Para Possenti (2002a), a autoria exige densidade, motivação, conhecimento de mundo, memória social e avaliação, ou seja, exige tomada de posição.

Se aproveitarmos a discussão de Possenti para refletirmos a respeito da produção de textos de crianças ainda mais jovens do que os jovens que ele tinha em mente ao redigir seu ensaio, poderemos dizer que reescrever um texto previamente lido exige produzir um desvio criativo, algo que, mesmo podendo ser classificado como "erro" por um adulto, configura um rudimento de estilo singular da criança que, se apoiando no equívoco como um fato estrutural da linguagem, gera uma criação (RIOLFI; BARZOTTO, 2011).

\subsubsection{A autoria enquanto posicionamento subjetivo}

O processo de criação é regulado por duas vertentes em constante tensão, uma tendendo para o uno (a cultural) e outra que o refrata e tende para o múltiplo (a subjetiva) (RIOLFI; BARZOTTO, 2011). Por esse motivo, ao escrever um texto, aquele que redige precisa decidir entre expor a sua singularidade, mantendo-se fiel a um estilo próprio, e valerse das máscaras sociais que, muitas vezes, funcionam como "pré-condição para o sucesso" (RIOLFI; MAGALHÃES, 2008).

Por singularidade, entendemos o produto do agenciamento harmonioso, por parte do enunciador, das diversas vozes presentes em seu texto. Sua manifestação depende, sobretudo, de que o sujeito autorize-se a escrever de modo a não necessariamente corresponder ao modelo imposto pela instituição que demanda a escrita (no caso, a escola).

Assim, concordamos com Magalhães (2007) a respeito da possibilidade de que, em relação aos textos lidos previamente à sua escrita, o escritor escolha entre três posturas: a) ignorar o que já foi produzido; b) tomar como modelo incondicional o que já foi produzido, imitando-o; e c) entender como ponto de partida o que já foi produzido e estabelecer "uma nova regra de produção" que continue circulando na comunidade. Transitando entre os três procedimentos, o sujeito produz diferentes textos.

Partindo da proposição de Magalhães (2007), Riolfi e Magalhães (2008) sistematizaram diferentes posições subjetivas que o aluno pode ocupar operando sobre a linguagem ao escrever. As autoras constroem uma gradação de posições desde a maior até a menor alienação à palavra do outro. A posição mais alienada é aquela na qual o sujeito está 
aderido à palavra do outro, e, portanto, não consegue retroagir para operar sobre ela, limitando-se a reproduzi-la. A posição menos alienada, por sua vez, é aquela na qual o sujeito consegue construir metáforas criativas, ou seja, ressignifica elementos disponíveis na cultura de modo singular. Entre elas, há duas posições intermediárias: a de quem, deliberadamente, limita-se a atender uma demanda escolar e a de quem, indo um pouco além disso, o faz de uma posição na qual se vislumbra algo do desejo do sujeito.

Diante da solicitação de reescrita fiel de textos-fonte previamente lidos, a expectativa docente é a de que os alunos, restringindo-se ao comando da atividade, ocupem uma posição marcada pela reprodução do texto do outro. Após a sua leitura, contudo, os alunos podem optar, além desse, por mais dois outros caminhos: ignorar o texto-fonte e, portanto, a demanda; e encarar o texto-fonte como ponto de partida para a criação de um texto que diga algo de si ou, ainda além, que contribua com a cultura de maneira única. Frente a essas possibilidades, nos interessa analisar as marcas da posição subjetiva que os participantes de pesquisa dão a ver em seus textos.

\subsubsection{A autoria enquanto estilo}

Partilhamos com Costa $(2016 ; 2019)$ a premissa segundo a qual é possível encontrar, em textos redigidos por alunos do Ensino Fundamental I, marcas linguísticas ou extralinguísticas que evidenciem o surgimento de estilo, isto é, aquilo que se manifesta nos "modos por meio dos quais seres humanos se assujeitam a uma cultura" e nos "modos como eles colocam-se em uma posição desde a qual possam transcendê-la em suas produções", indo além do esperado (COSTA, 2019, p. 90).

Tendo analisado textos redigidos por jovens autores, alunos das séries iniciais do Ensino Fundamental I, Costa (2016) notou indícios de um posicionamento singular por parte das crianças, cujas escolhas linguísticas (de vocabulário) e discursivas (de personagem, contexto narrativo etc.) tornaram seu texto único, embora ainda bastante próximo do texto inicialmente ofertado como inspiração para os alunos.

A maneira como os participantes de pesquisa apropriaram-se da palavra alheia (mais especificamente, do texto lido), dizendo também a sua palavra sem ignorar a solicitação, indiciou um surgimento de estilo.

No contexto específico de nosso trabalho, tomaremos o estilo como fruto de escolhas e inovações em relação ao texto-fonte feitas por estudante que, embora tenham sido solicitados 
a reescrever fielmente textos de terceiros, encontram margem para a criação sem, por isso, colocarem-se à margem da demanda escolar. Três aspectos principais o constituem: a alteridade, o risco e a linguagem (COSTA, 2019).

A) A alteridade: para sustentar o estilo, é preciso que se considere o outro, isto é, aquele a quem o texto se endereça. As manifestações do estilo precisam, em primeiro lugar, ser reconhecidas por uma comunidade, cujos membros determinam o que é ou não aceito. É o caso, por exemplo, de diferenciar o comportamento esperado em uma entrevista de emprego daquele adotado durante uma conversa despretensiosa no ponto de ônibus. No contexto específico de nosso estudo, trata-se de considerar a demanda escolar a qual se está submetido.

B) O risco: para sustentar o estilo, há que se correr o risco de ser amado ou odiado quando da tentativa de superar o que o outro espera. Para chegar a constituí-lo, além de calcular a expectativa cultural, é preciso que o sujeito deposite algo de si em sua fala, colocando à prova da comunidade algo até então desconhecido. Trata-se, no presente caso, de responder à demanda escolar "com o que há de mais representativo de si”" (COSTA, 2019, p. $83)$.

C) A linguagem: os efeitos estilísticos dessa superação se dão no campo da linguagem, da qual o sujeito falante se apropria para satisfazer seus desejos de expressão. Uma vez que a falta é constitutiva da linguagem, múltiplas são as possibilidades de subversão do sistema cultural por meio dela. Os recursos linguísticos e composicionais que engendram esse desvio são parte integrante do estilo individual.

Para nós, a autoria de um texto está vinculada ao modo como os participantes de pesquisa deixam entrever marcas de um estilo próprio, decorrente de escolhas linguísticodiscursivas que desempenham, durante a reescrita de textos-fonte.

Assim, por ocasião de nossas análises, observaremos as estratégias utilizadas por crianças que, levando em conta o conjunto de valores estabelecidos pelas interações sociais, podem chegar a desviar-se das formas padronizadas de expressão. Nesse intuito, mobilizaremos como aspectos da análise as maneiras como os participantes relacionam-se com a alteridade, com o risco (se é que o fazem) e com a linguagem.

Isso posto, estamos em condições de definir o conceito operacional de autoria do qual nos valemos. Entendendo que, no caso de crianças, o caminho mais produtivo seja procurar por sinais que apontam para a autoria em advento, compreendemos que esses só podem resultar da associação entre o surgimento de um estilo próprio e um posicionamento 
enunciativo a partir do qual, promovendo o arranjo das palavras e das outras vozes que agencia, resultantes de discursos com os quais teve contato, o sujeito diga também a que veio.

\subsection{Reformulações parafrásticas como objeto de estudo}

Para construir uma abordagem que permita o estudo de textos reescritos por crianças, partimos do texto de Catherine Fuchs (1985), trabalho que nos auxilia a conceber a tarefa de reescrever textos lidos em termos de sucessivas reformulações parafrásticas.

\subsubsection{Retomar um texto-fonte é reformulá-lo}

Um dos modos de abordar o que ocorre quando crianças são convidadas a reescrever textos-fonte é discutir a ocorrência de paráfrase linguística, uma reformulação realizada pelo sujeito que retoma determinada frase (FUCHS, 1985). Aproximando-se da tradição retórica e literária, Fuchs $(1985$, p. 133) propõe abordar a paráfrase no plano do discurso, como "[...] uma atividade efetiva de reformulação pela qual o locutor restaura (bem ou mal, na totalidade ou em parte, fielmente ou não) o conteúdo de um texto-fonte sob a forma de um textosegundo.".

A autora afasta-se de uma primeira hipótese, segundo a qual a paráfrase consistiria em equivalência formal, mostrando que ela é derivada da perspectiva da lógica formal, para a qual duas proposições são equivalentes quando têm o mesmo valor de verdade. Quando se trata da linguagem natural, essa visada gera problemas porque sentenças com o mesmo valor de verdade proposicional podem ser muito diferentes formalmente, como se nota comparando-se os dois enunciados a seguir:

e1: João matou José.

e2: José foi morto por João.

Para Fuchs (1985), existem problemas em postular a equivalência entre el e e2. Destaca-se o relativo à ênfase: em $e 1$ importa quem matou e, em $e 2$, quem morreu.

A autora afasta-se de uma segunda hipótese, derivada da gramática praticada na Antiguidade Clássica, mostrando que ela depende de um julgamento subjetivo intuitivo dos falantes a respeito do que é idêntico ou não. Embora a identidade de um referente qualquer possibilite considerar a paráfrase como sinonímia, a diversidade de pontos de vista dificulta 
essa visada. Por exemplo, um mesmo acontecimento pode ser qualificado como "milagre" ou "catástrofe" dependendo de seus efeitos sobre o locutor.

Defendendo sua hipótese de trabalho, ela apresentou três argumentos.

O primeiro é o de que "[...] a reformulação parafrástica repousa sobre uma interpretação prévia do texto-fonte" (FUCHS, 1985, p. 134). Isso significa que o trabalho de reformulação parafrástica é variável, o que se deve ao fato de que as interpretações do textofonte são múltiplas, ou seja, cada qual percebe e restaura o texto lido de modo diverso.

O segundo é o de que "[...] a reformulação parafrástica consiste em identificar a significação do texto-fonte assim reconstruída àquela do novo texto" (FUCHS, 1985, p. 134). Ao reformular, os sujeitos veem-se convidados a decidir entre manter ou não sua diferença em relação ao autor do texto parafraseado. Quando, por exemplo, resumimos uma fala com a qual não concordamos, quase fatalmente nos vemos compelidos a introduzir marcas de nossa divergência em uma síntese que inicialmente se propunha neutra.

O terceiro é o de que "[...] a reformulação parafrástica se traduz por formas características de emprego metalinguístico da linguagem" (FUCHS, 1985, p. 134). Em outras palavras, muitas vezes o objetivo de parafrasear a si próprio na direção de bem-dizer é explícito e move o locutor.

\subsubsection{Entre o mesmo e o novo}

Percebe-se, a partir do exposto, que o fato de se propor a parafrasear um segmento "X" qualquer não condena uma pessoa a meramente reproduzir seu conteúdo. Nesse sentido, pautado em assertivas de Fuchs (1994), Hilgert (2006) sustenta que enunciados em "relação parafrástica" nunca estabelecem entre si correspondência absoluta, mas apresentam maior ou menor grau de equivalência.

Considerando que a emergência de uma paráfrase é viabilizada por condições interpretativas e que essas, por sua vez, dependem do contexto sócio-histórico, da bagagem cultural e do conhecimento partilhado (FUCHS, 1994), decorre que "as paráfrases sempre implicam algum deslocamento de sentido, concorrendo para a progressividade textual" (HILGERT, 2006, p. 275).

Segundo Hilgert (2006, p. 277), não basta que dois enunciados tenham "seu parentesco semântico determinado por um núcleo de sentido comum invariável" para estarem em relação parafrástica. Mais do que uma propriedade de formulações linguísticas específicas, 
o parafraseamento é uma estratégia adotada por interlocutores envolvidos com os propósitos da ação interativa para produzirem referências textuais.

Assim, as maneiras de reconstruir o texto em sua leitura são múltiplas (LAJOLO, 1982). Logo, compreender o quanto as crianças de oito anos conseguem efetuar reformulações parafrásticas pertinentes, restaurando o conteúdo de um texto-fonte sob a forma de um texto-segundo (FUCHS, 1985), é um modo de verificar a ocorrência de leitura compreendida como a construção de sentidos (MARCUSCHI, 2008). Esse apontamento sustenta-se no fato de que a tarefa de recontar textos previamente lidos tem sido, há algum tempo, considerada uma medida confiável de compreensão leitora por pesquisadores internacionais (LESLIE; CALDWELL, 2009) e nacionais (KIDA et al., 2015).

Dada a propriedade da linguagem de ser estruturada na relação contraditória entre a paráfrase (reiteração do mesmo) e a polissemia (produção da diferença) (ORLANDI, 1996), parece-nos que a investigação a respeito da possibilidade de educar crianças para conquistar a autoria não pode ser desconsiderada, mesmo em um estudo a respeito da reescrita de textos escritos por terceiros em instituição escolar, onde há uma expectativa de realização de paráfrases muito próximas ao texto-fonte.

Assim, a obra de Fuchs (1985) nos auxilia a perceber que, quando convidadas a reescrever um texto-fonte, as crianças encontram-se em uma oscilação entre a reprodução do mesmo e a criação do novo. Compreendemos que, em contexto de ensino de Língua Portuguesa, trata-se de levar as crianças a conquistar sua voz entre essas duas polaridades. Isso nos convida a observar o que Riolfi e Barzotto (2011, p. 98) qualificam como os "[...] diferentes modos por meio dos quais os sujeitos se organizam entre si e com o saber historicamente constituído." 


\section{As operações sistemáticas da escritura}

Neste capítulo, após descrevermos as formas de organização e recorte do corpus de pesquisa, bem como de cotejamento entre os manuscritos produzidos pelos participantes e os textos-fonte que lhes serviram de base, procederemos à análise de como as operações sistemáticas da escritura (GRÉSILLON; LABRAVE, 1983; GRÉSILLON, 2007) são executadas pelos alunos. Interessa-nos, ainda, olhar para a recorrência com que algumas transformações são efetuadas por eles.

\subsection{A organização do corpus e seu recorte}

A partir da realização da primeira coleta, em agosto de 2016, iniciou-se o processo de catalogação e organização do corpus de pesquisa, do qual os primeiros exemplares foram os textos produzidos pelos alunos dos $3^{\text {os }}$ anos I e II durante as avaliações de fevereiro e abril daquele ano.

O movimento inicial foi o de digitalização das produções. Os arquivos salvos foram separados de acordo com a turma, de modo que, terminado o processo de coleta, estavam armazenados como apresentado na figura 2.

Figura2: Agrupamento dos textos constituintes do corpus por turma participante

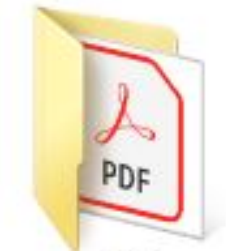

$3^{\circ} 1$

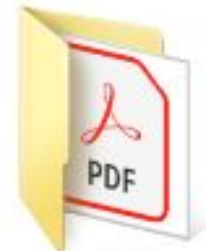

$3^{\circ} \|$

Fonte: elaborada pela autora, 2020

Dentro de cada uma das pastas, os arquivos foram separados de acordo com o textofonte que serviu de base aos alunos durante as atividades de reescrita, conforme exemplificado nafigura3. 
Figura3: Agrupamento dos textos constituintes do corpus por texto-fonte reescrito

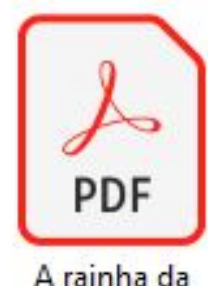

bateria

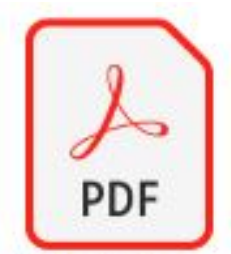

João-de-barro

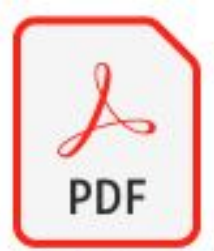

Maria Angula (Equador)

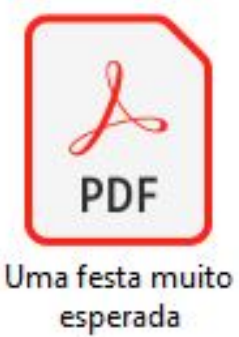

esperada

Fonte: elaborada pela autora, 2020.

Após a realização da quarta tarefa, foi possível contabilizar as produções. A população de 59 crianças escreveu, no total, os 236 textos que compõem nosso corpus e que, em março de 2018, passaram a fazer parte do banco de dados do Grupo de Estudos e Pesquisa Produção Escrita e Psicanálise - GEPPEP.

Após a sistematização do corpus, iniciou-se o cotejamento entre os textos-fonte e as reescritas dos participantes. Decorreram, desse processo, dois tipos de análise. O primeiro, de caráter predominantemente quantitativo, tomou a sentença como unidade. O segundo elegeu o texto como objeto e teve caráter qualitativo. Nos dois casos, os gestos analíticos efetuados seguiram a tradição já estabelecida pelos autores que, há décadas, vêm, de diversos modos, se utilizando de elementos retirados da crítica genética para analisar manuscritos redigidos por crianças (CALIL, 1996; 1998; CALIL; LIMA, 2007).

Devido ao grande volume de material a ser analisado, foi necessário fazer um recorte do corpus para proceder ao cotejamento do texto-fonte e de sua reescrita pelos participantes. Como o deslocamento de uma parte do texto-fonte para outra completamente diferente no texto reescrito inviabiliza a descrição da operação efetivamente realizada pelo aluno, decidimos começar nosso estudo exploratório verificando como as crianças reagem quando convidadas a reescrever a primeira frase de textos-fonte, a saber: a) Frase de abertura do texto "A rainha da Bateria" (VILA, 2009), utilizado na avaliação de fevereiro; b) Frase de abertura do texto "João-de-barro" (SÓHISTÓRIA, 2019), utilizado na avaliação de abril; c) Frase de abertura do texto "Maria Angula (Equador)" (URIBE, 1999), utilizado na avaliação de agosto; e d) Frase de abertura do texto "Uma festa muito esperada" (TOLKIEN, 2001), utilizado na avaliação de novembro.

Entre tantos outros recortes possíveis, as primeiras frases foram escolhidas porque, nos textos-fonte que compõem o corpus, elas cumprem o papel de introduzir referentes no texto, 
apresentando ora o protagonista da narrativa (Maria Luisa; Maria Angula; Bilbo Bolseiro), ora o seu principal assunto (o pássaro joão-de-barro).

\subsection{As operações sistemáticas da escritura}

$\mathrm{Na}$ análise, diferentemente do que fez Campos (2008), não julgamos produtivo avaliar as modificações realizadas pelos participantes ao reescrever em termos de "empobrecer" ou “enriquecer" o texto-fonte. Nossa visada foi analítico-descritiva.

A fim de agrupar o estudo das diferenças entre o texto original e o texto do participante, iniciamos nossa análise verificando como, ao reescrever os textos-fonte, as crianças utilizavam-se das operações sistemáticas da escritura (GRÉSILLON; LABRAVE, 1983; GRÉSILLON, 2007), quais sejam:

1. Acréscimo: inserção de palavras, sintagmas ou frases. Além de considerar a adição de personagens, diálogos e eventos feita pelo aluno avaliado, aqui se analisa, no texto do estudante, a ocorrência de estruturas não previstas, considerando-se o gênero ou a norma culta;

2. Deslocamento: transposição de uma parte do texto de um lugar para outro, cujos exemplos são, principalmente, de mudança na ordem das expressões parafraseadas. Nesse caso, são analisadas, entre outras, passagens enfatizadas pelas crianças de modo contrastante ao que se faz no texto lido;

3. Substituição: troca de uma parte do texto por outra. Configuram bons exemplos disso as permutas que as crianças fazem de um termo por outro aparentemente sinônimo no momento da reescrita; e

4. Supressão: abandono de uma parte do texto. Faz referência, por exemplo, ao modo

como as crianças reproduzem fragmentos sobre morte, separação, horror, miséria, entre outros, de modo a muitas vezes omiti-los ou torná-los menos impactantes.

Além disso, também observamos as ocasiões em que os participantes não alteraram o texto-fonte, tendo, surpreendentemente, conseguido reter na memória grandes porções da formulação original.

No que segue, exemplificaremos o tipo de cotejamento realizado, dando um exemplo de cada operação sistemática de escritura e um de reprodução fiel da frase de abertura do texto-fonte. 


\section{A) Acréscimo}

Frase inicial do texto-fonte: Maria Angula era uma menina alegre e viva, filha de um fazendeiro de Cayambe. (URIBE, 1999).

Excerto 1: "Maria Angula era uma menina alegre e fofoqueira maltratava os animais e os colegas ela era filha de um fazendeiro morava numa cidade Cayambe." (grifo nosso).

Cotejando o excerto 1 com o texto-fonte, percebemos um procedimento que caracteriza "operação de argumentação" (GERALDI, 1997). Nele, a criança acrescentou, ao interior do texto, elementos constituidores de argumentos. Extrapolando a introdução da versão original, ela apresenta a personagem Maria Angula como sendo uma menina que maltrata os animais e os colegas.

Assim, para além do que efetua Uribe (1999), a criança marca, textualmente, os motivos pelos quais o leitor deveria, desde o início da história, antipatizar com a protagonista. Essa marcação tem seu efeito acentuado quando se nota que, nesse mesmo excerto, ocorreu, também, uma operação de substituição, no caso, a do adjetivo "viva", de conotação positiva, por "fofoqueira", de conotação pejorativa.

Mesmo tentando evitar um olhar valorativo sobre as operações realizadas pela criança, cumpre dizer que suas alterações são bastante pertinentes com relação à totalidade do textofonte, cuja história original apresentava uma protagonista fofoqueira e dada à prática de ações que poderiam ter sido avaliadas como maldades pelas crianças.

\section{B) Deslocamento}

Frase inicial do texto-fonte: Quando Bilbo Bolseiro anunciou que celebraria seus 111 anos de idade, no dia 22 de setembro, com uma festa de especial grandeza, houve muito comentário e agitação na Vila dos Hobbits. (TOLKIEN, 2001).

Excerto 2: "O Bilbo Bolseiro anunciou que comemoraria seu aniversário de 111 anos no dia 22 de setembro com festa especial grandeza, na Vila dos Hobbits havia muito comentário e agitação." 
Cotejando o excerto 2 com o texto-fonte, percebemos o deslocamento do sintagma "na Vila dos Hobbits", que, na versão reescrita pela criança, foi topicalizado. A promoção desse deslocamento, somada à supressão do advérbio "quando" no início da frase, caracteriza o uso da justaposição no lugar da relação de subordinação entre as orações, que passam a apresentar o mesmo grau de proeminência.

\section{C) Substituição}

Frase inicial do texto-fonte: Maria Luisa, filha da dona Luzia, era uma menina que gostava de música brasileira - samba, chorinho, bossa nova, canção, calango, baião, xote... (VILA, 2009).

Excerto 3: "Era uma vez uma menina chamada Maria Luisa ela gostava de músicas de carnaval." (grifo nosso).

Cotejando o excerto 3 com o texto-fonte, percebe-se que a expressão "música brasileira" foi substituída por "músicas de carnaval". É possível que tal escolha tenha sido feita porque, na avaliação da criança, essa expressão poderia configurar uma operação de condensação (GERALDI, 1997) de "samba, chorinho, bossa nova, canção, calango, baião, xote".

D) Supressão

Frase inicial do texto-fonte: Contam os índios que foi assim que nasceu o pássaro joão-de-barro. (SÓHISTÓRIA, 2019).

Excerto 4: "Contam os índios que foi assim que nasceu o joão-de-barro."

Cotejando o excerto 4 com o texto-fonte, verificamos a ocorrência da supressão do determinante "pássaro". Provavelmente, a criança julgou não haver necessidade de manter a operação de determinação (GERALDI, 1997) presente no texto original, muito possivelmente por saber que não existem outros animais além de passarinhos chamados de joão-de-barro. 
E) Reprodução fiel

Frase inicial do texto-fonte: Contam os índios que foi assim que nasceu o pássaro joão-de-barro. (SÓHISTÓRIA, 2019).

Excerto 5: "Contam os índios que foi assim que nasceu o pássaro joão-de-barro.”

Cotejando o excerto 5 com o texto-fonte, verifica-se que, conforme esperado pelas professoras das turmas, é possível que alunos muito jovens reproduzam de maneira fiel, apelando à memória, frações significativas de texto. Nesses casos, nota-se o completo apego ao texto-fonte e às vozes institucionais.

\subsection{Análise quantitativa das operações sistemáticas da escritura}

A análise quantitativa revelou a presença das quatro operações sistemáticas da escritura (GRÉSILLON; LABRAVE, 1983; GRÉSILLON, 2007), em diferentes proporções. Observa-se, ainda, que o número de vezes nas quais os participantes mantiveram o seu texto idêntico ao texto-fonte é substancialmente menor do que o número de ocasiões em que os alunos promoveram alguma alteração em relação ao mesmo.

Antes de apresentar as análises gráficas, cumpre ressaltar que, como cada criança pode ter realizado mais de uma operação no momento da reescrita, a soma ultrapassa 236, isto é, o total de produções analisadas. Os gráficos 1, 2, 3 e 4, a seguir, mostram a frequência das transformações comparada ao número de reproduções fiéis por texto-fonte. O primeiro deles refere-se à avaliação de fevereiro, em que o texto "A rainha da bateria" (VILA, 2009) foi trabalhado. 
Gráfico 1: Ocorrência de operações sistemáticas da escritura na reescrita de "A rainha da bateria" (VILA, 2009)

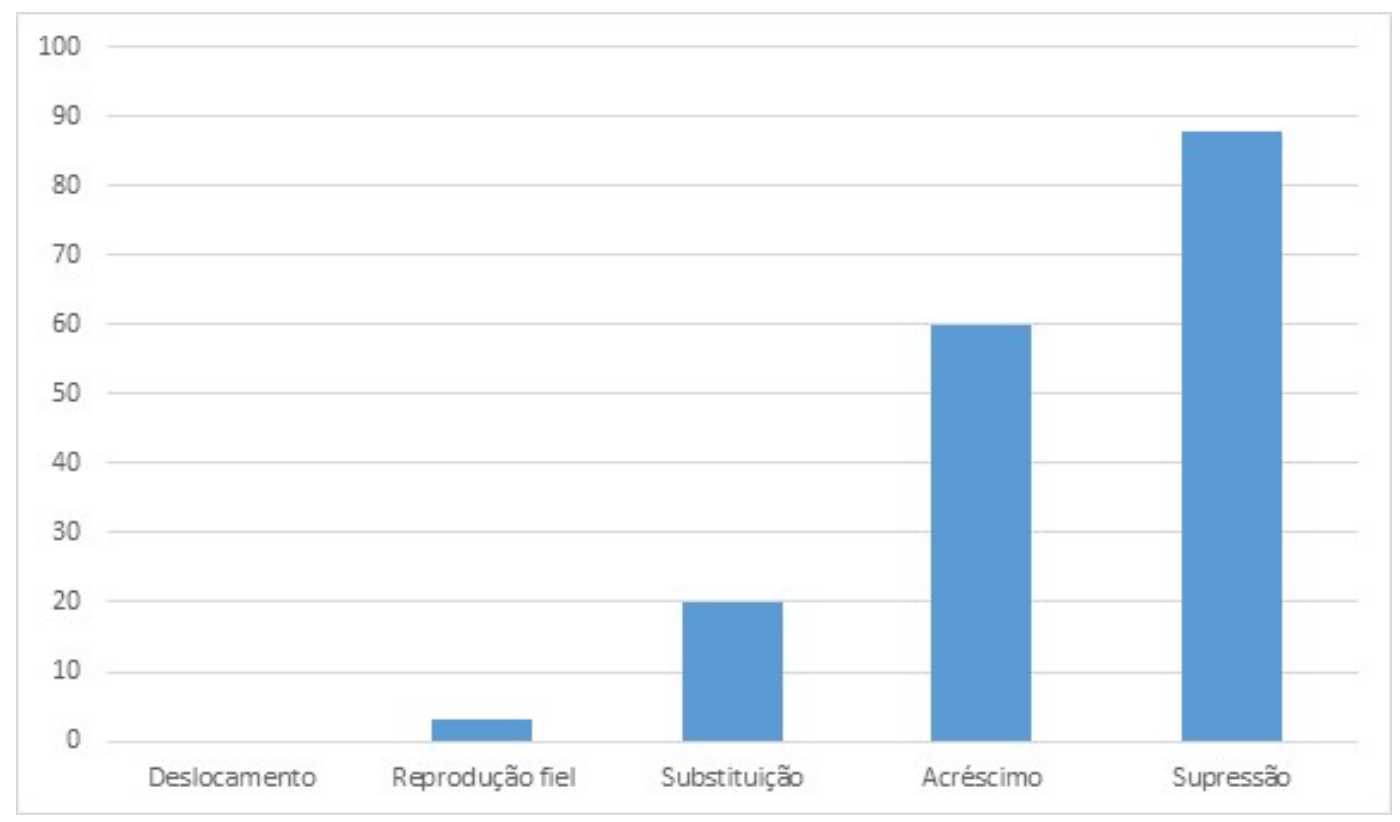

Fonte: elaborado pela autora, 2020.

Procederemos à análise do gráfico começando pelo menor número de ocorrências e avançando em direção ao maior. Nota-se que não houve sequer uma operação de deslocamento durante a reescrita da frase inicial do primeiro texto-fonte. Acreditamos que, por introduzirem referentes importantes do texto, a transposição de alguns elementos é dificultada, especialmente quando falamos de escritores muito jovens.

Quanto às reproduções fiéis do texto lido, elas representam 5\% das produções (somam três casos, portanto), seguidas das substituições, que somam 20. Predominam as substituições de "menina" por "menininha", talvez porque a personagem tenha sido caracterizada como alguém de pouca idade; de "pai" por "avô", talvez porque o personagem tenha falecido, apontando para a memória de lida com a morte das crianças; e de "música brasileira" por "música de carnaval", provavelmente porque frações do conto sejam ambientadas em uma escola de samba.

Para exemplificar os efeitos dessa última operação ao longo do texto, apresentaremos, no quadro 1, um trecho do texto "A rainha da bateria" (VILA, 2009) com o qual cotejaremos as reescritas do mesmo fragmento por duas crianças, J. e S., presentes nos quadros 2e $3 \mathrm{a}$ seguir. 
Cumpre dizer que, nessa passagem do texto-fonte, o narrador explica que o gosto por MPB que a protagonista do conto nutre deve-se à influência de seu pai, amante de nossos grandes artistas.

Quadro 1: Fragmento do texto-fonte "A rainha da bateria" Ele [o pai de Maria Luisa] os [discos dos nossos grandes artistas] passou para um iPod e deu de presente para a filha.

Fonte: VILA (2009)

Quadro 2: Manuscrito e transcrição diplomática de fragmento da reescrita produzida por J.

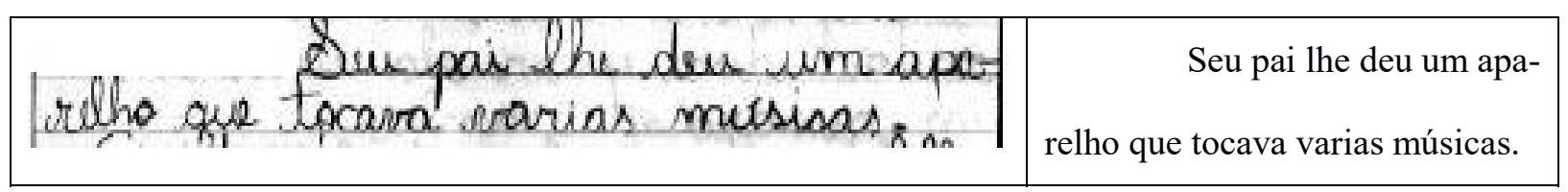

Fonte: manuscrito de pesquisa, coletado e transcrito pela autora, 2020

Quadro 3: Manuscrito e transcrição diplomática de fragmento da reescrita produzida por S.

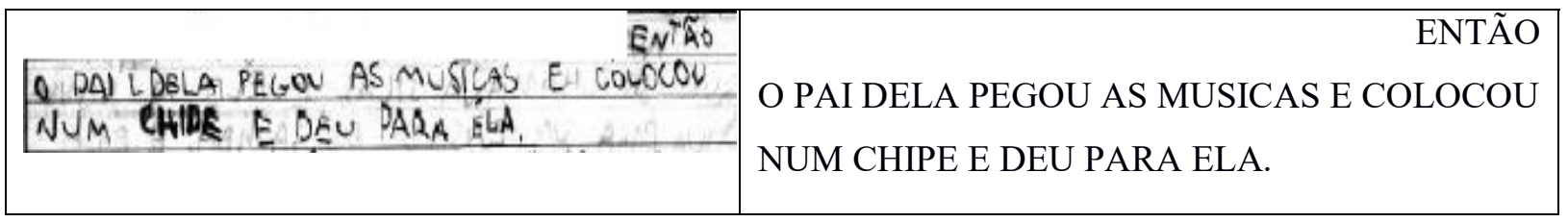

Fonte: manuscrito de pesquisa, coletado e transcrito pela autora, 2020

Nota-se que o termo "iPod", presente na versão original do texto, dá lugar às expressões "aparelho que tocava várias músicas" e "chipe" nas produções de J. e S., respectivamente. Essa tendência se confirma quando, na análise das 59 reescritas da história, constata-se que apenas oito alunos (13,5\%, portanto) fizeram uso de "iPod". A hipótese é a de que se tratava de um dispositivo incomum no universo das crianças selecionadas como participantes, o que não configuraria uma exceção dado que, à época da pesquisa, o preço do iPod equivalia a meio salário mínimo. Isso porque boa parte delas residia na periferia da zona oeste de São Paulo e provinha de famílias pouco abastadas.

Se essa hipótese estiver correta, trata-se de relativizar ponderações segundo as quais existem dois tipos de instrumentos avaliativos: aquele cuja proposta de produção textual leva o aluno a expressar um posicionamento e aquele em que não há espaço para o aluno fazê-lo. O exercício de reescrita de textos de terceiros provavelmente pertenceria a esse último grupo. No entanto, o que se nota é o pronunciamento de uma visão de mundo por parte das crianças. 
Voltando ao gráfico, observa-se que o acréscimo é a segunda operação mais executada pelas crianças, totalizando 60 casos. As ocorrências mais comuns são a inserção da expressão "era uma vez" no início do texto e a atribuição de adjetivos à protagonista da história e à sua mãe assim que elas são apresentadas ao leitor. Acreditamos que os dois procedimentos aproximam a narrativa dos contos fantásticos frequentemente lidos pelos alunos em sala e fora dela.

Finalmente, cumpre dizer aquilo que foi suprimido da primeira frase do texto-fonte quando da reescrita por parte das crianças. Entre os 88 casos de supressão, mais da metade responde pelo trecho em que são listados os gêneros musicais de interesse da protagonista (samba, chorinho, bossa nova, canção, calango, baião e xote). Apenas três dos 59 alunos (5\%, portanto) retomaram com fidelidade esse fragmento da obra.

À medida que a lista de gêneros avança (do samba ao xote), observa-se um número cada vez menor de reescritas idênticas. Ou seja, a aparição do termo "samba" supera em número a aparição de "chorinho", que, por sua vez, supera a de "bossa nova" e assim sucessivamente. Nossa hipótese é a de que, ao longo da leitura, as crianças memorizam mais facilmente vocábulos com os quais operam cotidianamente. No presente contexto, esse não parece ser o caso de "calango", "baião" e "xote", por exemplo.

O aposto intercalado por vírgulas no texto-fonte, cuja função é informar sobre o parentesco da protagonista, ocupa a segunda posição entre os excertos mais frequentemente suprimidos. Acreditamos que o dado se deva à complexidade dessa construção e ao fato de que a ausência de tal informação no início do texto não compromete o enredo, percepção da qual talvez os alunos se valham (ainda que não intencionalmente).

A seguir, por meio do segundo gráfico, analisaremos a ocorrência de operações sistemáticas da escritura durante a atividade que tomou, como texto-fonte, "João-de-barro" (SÓHISTÓRIA, 2019). 
Gráfico 2: Ocorrência de operações sistemáticas da escritura na reescrita de "João-de-barro"

(SÓHISTÓRIA, 2019)

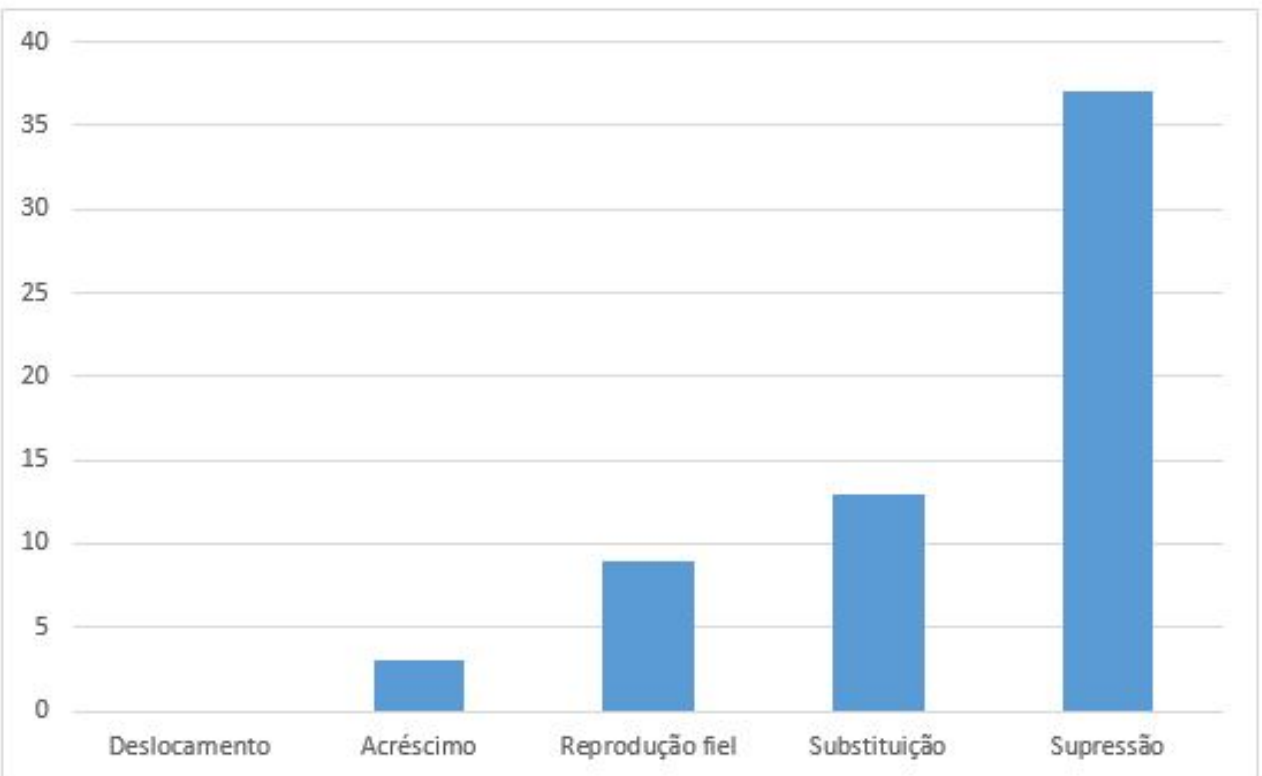

Fonte: elaborado pela autora, 2020.

Analogamente ao que ocorre na reescrita do texto "A rainha da bateria" (VILA, 2009), zero foi o número de deslocamentos efetuados pelos alunos durante a atividade proposta em abril no que concerne à primeira frase de "João-de-barro".

Trata-se de uma sentença bastante simples, e é possível que a isso se deva o maior número de reproduções fiéis, totalizando 9 (15\% das produções, portanto). Compõe-se por uma oração em que se evidenciam o sujeito (“os índios”) e o verbo ("contam”) em hipérbato e duas orações que, em conjunto, complementam o sentido do verbo ("que foi assim que nasceu o pássaro joão-de-barro").

Os elementos contidos na frase introduzem o aspecto lendário do texto e o assunto sobre o qual a lenda irá tratar, qual seja, a origem da ave. Em outras palavras, apresentam objetos de discurso do texto e, por isso, têm sua transposição dificultada sob pena de comprometer o encadeamento dos fatos da história.

Os acréscimos, por sua vez, foram apenas três e limitam-se a conferir novos atributos aos índios ("velhos" e "sábios") e ao pássaro ("belo"). Durante a reescrita do restante do texto-fonte, porém, notamos muitos casos de acréscimo em que as crianças parecem ter investido nas demonstrações de afeto (ou falta dele) pelos personagens. Para exemplificá-los, utilizaremos, reproduzido no quadro 4, o trecho original de "João-de-barro" (SÓHISTÓRIA, 
2019) no qual a amada de Jaebé pede à lua que o mantenha vivo e, reproduzida no quadro 5, a reescrita desse mesmo fragmento por A.

Quadro 4: Fragmento do texto-fonte "João-de-barro"

A jovem apaixonada chorava e implorava à deusa Lua que o mantivesse vivo.

Fonte: SÓHISTÓRIA (2019)

Quadro 5: Manuscrito e transcrição diplomática de fragmento da reescrita produzida por A.

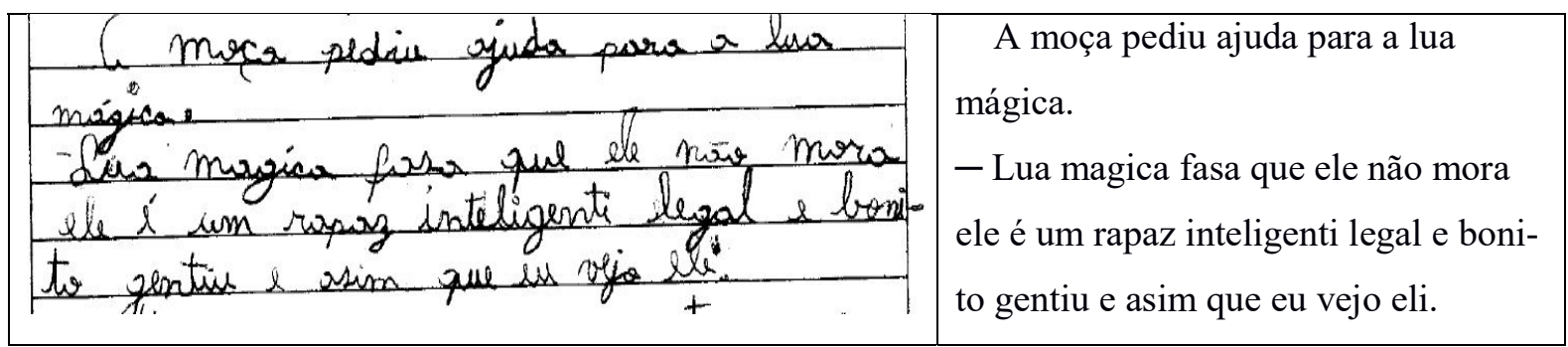

Fonte: manuscrito de pesquisa, coletado e transcrito pela autora, 2020

Como se observa, a primeira alteração empreendida por A. em relação ao texto lido se dá no nível do tipo de discurso. Se, no texto-fonte, essa passagem está toda em discurso indireto, na reescrita da aluna ela é híbrida: parte ocorre em discurso indireto e parte, em discurso direto. Cotejando o excerto de texto-fonte com o de reescrita, nota-se que os adjetivos atribuídos à Jaebé constituem argumentos. Extrapolando a versão original, A. apresenta o protagonista como sendo inteligente, legal, bonito e gentil, termos não empregados na obra que lhe serviu de modelo e que, por isso, caracterizam adições.

Assim, para além do que efetua o autor de "João-de-barro", a criança marca, textualmente, os motivos pelos quais a lua deveria proteger Jaebé e o leitor deveria simpatizar com ele. Nesse sentido, alguns alunos optam por atribuir "moço forte", "corajoso", entre outros, ao protagonista.

Em relação a essa atividade, outros exemplos poderiam ser dados. O pai da moça, que impõe regras ao casamento de Jaebé e o desafia, em nenhum momento tem sua personalidade traçada pela versão original do texto. Entretanto, uma criança, por exemplo, atribui-lhe "bravo homem" e outra escreve que ele "não era uma boa pessoa".

Mesmo procurando não atribuir juízos de valor às modificações realizadas pelos participantes, cumpre dizer que elas são bastante pertinentes diante da totalidade do textofonte, cuja história apresenta um protagonista que, pressionado pelo futuro sogro a dar provas 
de seu amor, fica nove dias em jejum enquanto sua amada sofre. Essa prática do pai da moça poderia ter sido avaliada como uma maldade pelos estudantes.

Quanto às operações de substituição, em número de 13 , consistem na alteração dos dois sintagmas verbais (“contam" dá lugar a "dizem" e "nasceu” dá lugar a "surgiu", por exemplo), em um processo de sinonímia que não gera grandes impactos na significação, e na troca de "joão-de-barro" por "Jaebé", protagonista cujo nome, no texto-fonte, é apresentado ao leitor somente no segundo parágrafo. Aqui, a hipótese é a de que as crianças entenderam o termo "Jaebé" como sendo o nome do pássaro.

Enfim, a operação mais comum durante a resolução dessa segunda atividade avaliativa foi a supressão, em número de 37. Das ocorrências, 29 são de omissão total da frase inicial, de modo que os textos nesse caso iniciam-se pela marcação de tempo, espaço e exposição do acontecimento inicial que provoca o conflito da história, como é comum nas narrativas de aventura pelas quais as crianças demonstravam interesse durante as rodas de leitura promovidas pelas professoras; e quatro são apenas no termo "pássaro", o que não compromete a inteligibilidade do texto, em razão do joão-de-barro ser uma espécie de ave bastante conhecida. Logo, a construção "pássaro joão-de-barro" poderia soar como redundante ou, no mínimo, dispensável para algumas crianças.

Vejamos, a seguir, como se comportam os alunos durante a reescrita do terceiro textofonte, apresentado a eles em agosto, em termos de execução das operações sistemáticas da escritura (GRÉSILLON; LABRAVE, 1983; GRÉSILLON, 2007). 
Gráfico 3: Ocorrência de operações sistemáticas da escritura na reescrita de "Maria Angula (Equador)" (URIBE, 1999)

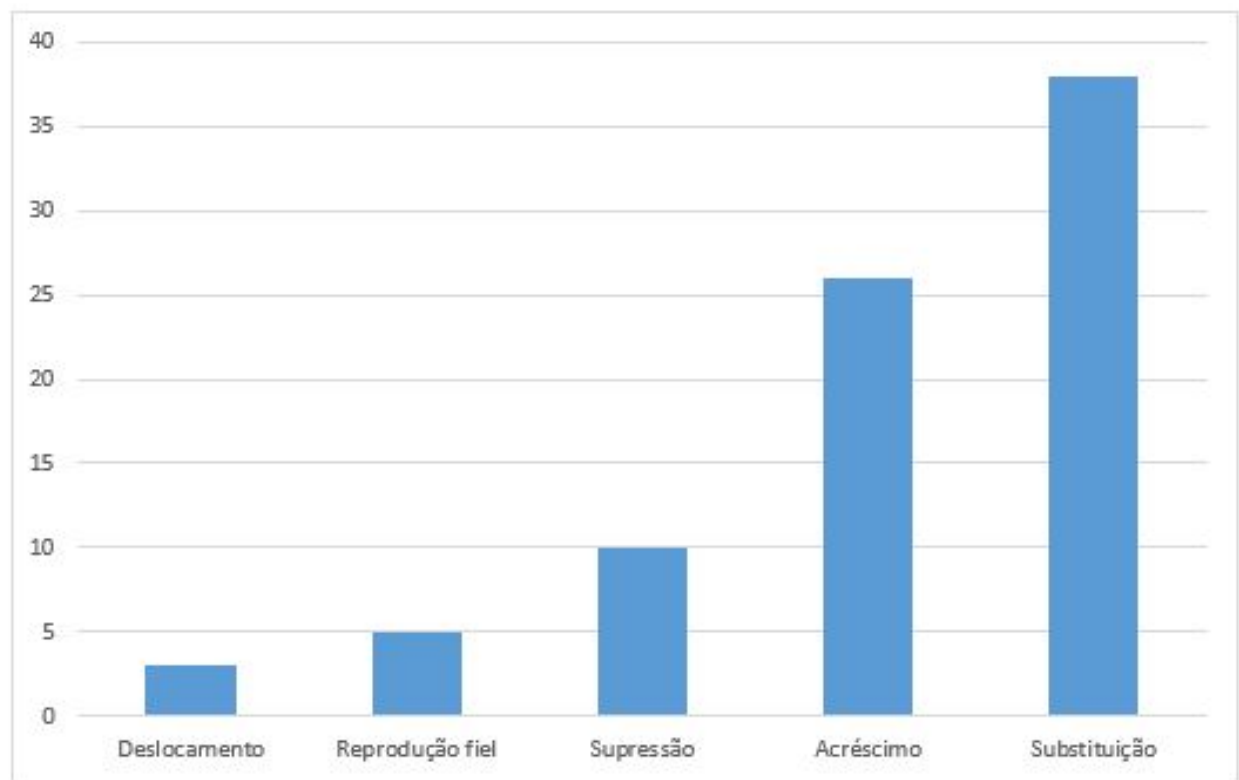

Fonte: elaborado pela autora, 2020.

Durante a atividade que tomou como texto-fonte o conto de assombração "Maria Angula (Equador)" (URIBE, 1999), pela primeira vez a operação de deslocamento foi efetuada pelos alunos. Nos três casos, tratou-se de deslocar o nome da personagem para o fim da frase. Como em uma tentativa de garantir o suspense da história desde o seu início, as crianças primeiramente mencionaram algumas de suas características (entre elas, a genealogia), para então nomeá-la.

Quanto às reproduções fieis do texto-fonte, foram em número de cinco, totalizando $8 \%$ das produções. Já as operações de supressão somaram dez casos, dos quais quatro foram do substantivo "menina", que antecedia os adjetivos atribuídos à protagonista; três foram da menção ao pai e à sua origem; e três foram das características que a definiam no início do conto ("alegre e viva"), as quais parecem contrastar com a imagem que os leitores fizeram dela após conhecer os fatos da narrativa a seu respeito, hipótese reforçada pela análise das substituições promovidas pelos participantes.

Embora não tenha sido bastante recorrente durante a reescrita da frase de abertura, a supressão foi frequentemente efetuada ao longo da reescrita do restante da história, especialmente no que concerne às suas partes aflitivas. Como exemplo de uma dessas passagens, apresentamos, no quadro 6a seguir, o trecho original de "Maria Angula (Equador)" 
(URIBE, 1999) em que a protagonista vai até o cemitério e retira as tripas de um cadáver a fim de com elas preparar um caldo para o marido.

Quadro 6: Trecho suprimido do texto-fonte "Maria Angula (Equador)"

E, num piscar de olhos, estava ela no cemitério, esperando pela chegada do defunto mais fresquinho. Quando já não havia mais ninguém por perto, dirigiu-se em silêncio à tumba escolhida. Tirou a terra que cobria o caixão, levantou a tampa e... Ali estava o pavoroso semblante do defunto! Teve ímpetos de fugir, mas o próprio medo a deteve ali. Tremendo dos pés à cabeça, pegou o facão e cravou-o uma, duas, três vezes na barriga do finado e, com desespero, arrancou-lhe as tripas e o estômago. Então voltou correndo para casa. Logo que conseguiu recuperar a calma, preparou a janta macabra que, sem saber, o marido comeu lambendo os beiços.

\section{Fonte: URIBE (1999)}

No caso, não há cotejamento entre versão original e reescrita infantil porque se trata de um movimento de supressão. Nesse sentido, a investigação apontou que, em um grupo de 59 alunos, apenas 13 deles (22\%, portanto) mencionam o processo de violação do morto pela personagem.

Entendemos que, para que as crianças de fato reproduzissem o conteúdo original, seria necessário que não existissem espaços para o exercício da escolha e, por conseguinte, da autoria.

Depreende-se, ainda, do gráfico 3 que 26 foram os acréscimos executados pelos alunos durante a atividade. Sete deles são da expressão "era uma vez" e cinco são casos em que, antes do nome Maria Angula, isto é, para introduzi-lo, foram incluídas as construções "era chamada de", "era conhecida como", "o nome dela era" e semelhantes.

$\mathrm{O}$ restante das adições parece estar a serviço de adiantar ao leitor que a narrativa centralizar-se-á nas aventuras de uma jovem dada à fofoca. Nesse sentido, junto aos adjetivos "alegre e viva", surgem "fofoqueira", "que gostava de fazer intrigas entre amigos para jogálos uns contra os outros", "que tinha fama de traz e volta", "cheia de fofocas fresquinhas para contar", "que maltratava os animais", "que vivia metendo as pessoas em frias", entre muitos outros.

Ao que parece, as crianças não só avançam em apresentar os atributos da protagonista aos quais se deve a sucessão dos fatos da história, como também reforçam os traços dela que lhes parecem nocivos, acrescentando a eles outros igualmente desfavoráveis que não existem 
no texto original, em um movimento contrário ao explicitado pela análise dos quadros 4 e 5 , na qual os participantes demonstram certa estima pelo personagem, igualmente deixando entrever indícios de um posicionamento.

Finalmente, resta mencionara substituição, operação mais executada ao longo desse terceiro exercício avaliativo. Em 31 das 38 ocorrências (81\%, portanto), alguns alunos foram além do que aqueles que apenas somaram aos adjetivos "alegre e viva", de conotação positiva, aspectos negativos do caráter de Maria Angula. Nesses casos, houve a completa substituição dos primeiros pelos segundos, de modo que, como foi dito na seção 3.2 deste capítulo, o leitor passa a ter razões para desgostar da personagem desde o início da narrativa.

Analisemos, a seguir, a ocorrência das mesmas operações durante a atividade aplicada em novembro nas turmas participantes.

Gráfico 4: Ocorrência de operações sistemáticas da escritura na reescrita de "Uma festa muito esperada" (TOLKIEN, 2001)

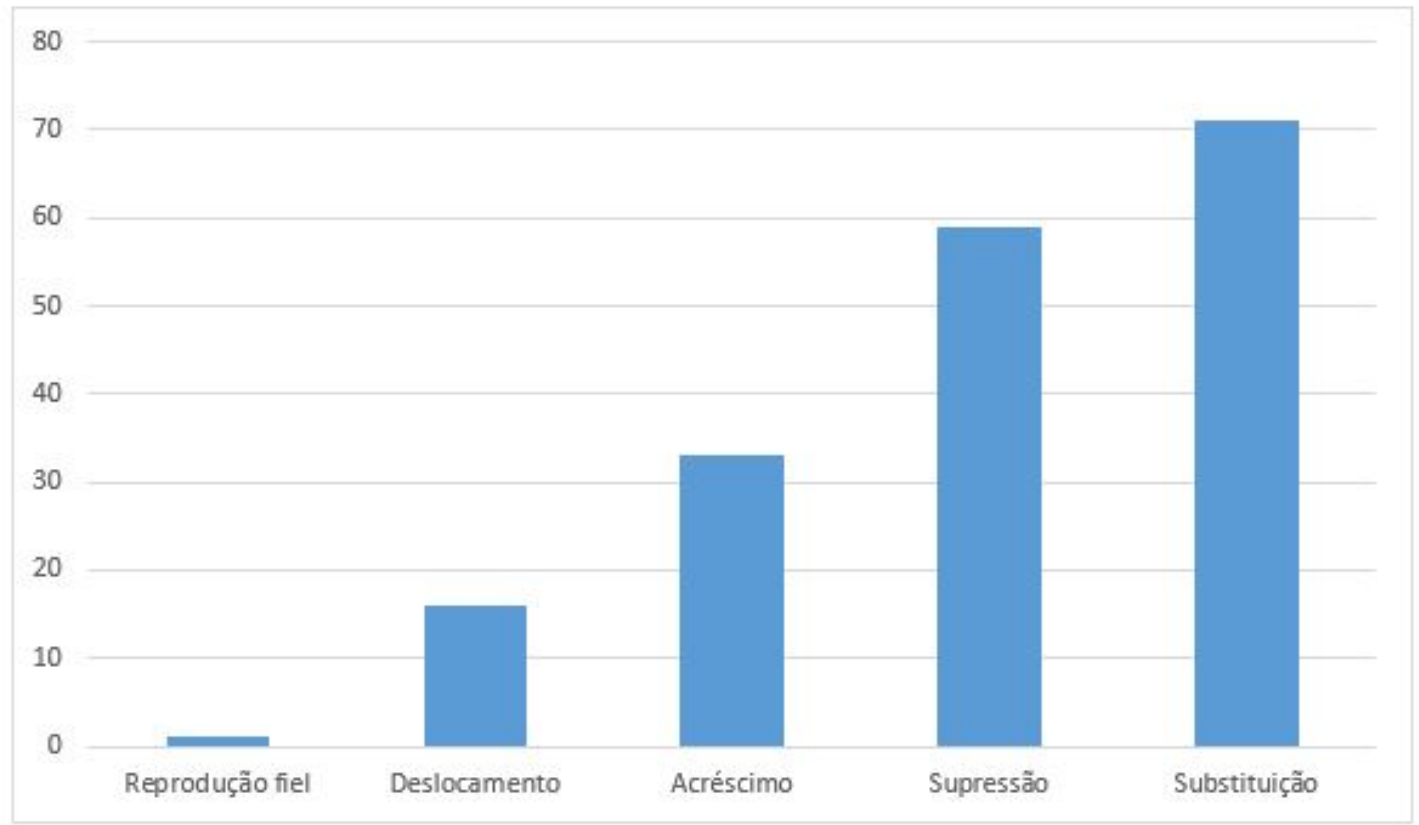

Fonte: elaborado pela autora, 2020.

Durante a reescrita da frase inicial de "Uma festa muito esperada" (TOLKIEN, 2001), adaptação do primeiro capítulo do primeiro volume da trilogia O Senhor dos Anéis (TOLKIEN, 2001), apenas uma criança reproduziu fielmente o texto-fonte, o que representa $1,6 \%$ do total. Acreditamos que o baixo número se deva à maior extensão e complexidade da frase em relação às demais analisadas. Nela, estão presentes uma oração principal ("houve 
muito comentário e agitação na Vila dos Hobbits") e uma oração subordinada adverbial temporal ("Quando Bilbo Bolseiro anunciou que celebraria seus 111 anos de idade"), um adjunto adverbial de tempo ("no dia 22 de setembro") e o outro de modo ("com uma festa de especial grandeza"), os quais foram frequentemente deslocados pelos alunos sem, por isso, comprometer a clareza do texto.

Embora o índice de ocorrências tenha aumentado substancialmente, chegando a 16 casos, o deslocamento continuou sendo a operação sistemática da escritura menos executada. Como tendência, os adjuntos adverbiais de tempo e modo foram retomados, pelos alunos, no fim da frase de abertura.

Somaram-se 33 situações de acréscimo, das quais chama atenção como mais recorrentes as menções a um convite para a festa que Bilbo teria feito à sua família; detalhes sobre o passado de Bilbo e Frodo, amparados pelo fato de que as crianças, em sala, haviam lido O Hobbit (TOLKIEN, 2013), que antecede a trilogia O Senhor dos Anéis (TOLKIEN, 2001), durante o trimestre; informações sobre a riqueza dessa personagem; referências às memórias de aventuras que Bilbo cultivava e à sua fama no condado; e alusões à ansiedade e animação que Bilbo sentira quando da organização da festa.

Durante a reformulação do restante do texto, contudo, parece haver uma predisposição, por parte dos alunos, a aproximar o texto (ou a história) de uma outra realidade que não a narrativa, mas a concreta. Nesse movimento, os acréscimos foram bastante recorrentes. A seguir, na reprodução de um fragmento de texto redigido por M. quando da reescrita de "Uma festa muito esperada" (TOLKIEN, 2001), nota-se a inclusão de um diálogo. Se, no texto original, Bilbo, no dia de sua festa, apenas recebe seus convidados e distribui para todos presentes, na reescrita de $\mathrm{M}$. uma conversa entre eles é adicionada. A versão de Tolkien (2001) encontra-se no quadro 7e a do aluno, no quadro 8.

Quadro 7: Fragmento do texto-fonte "Uma festa muito esperada"

O grande dia chegou e Bilbo recebeu pessoalmente todos os convidados e distribuiu presentes para todos.

Fonte: TOLKIEN (2001) 
Quadro 8: Manuscrito e transcrição diplomática de fragmento da reescrita produzida por M.

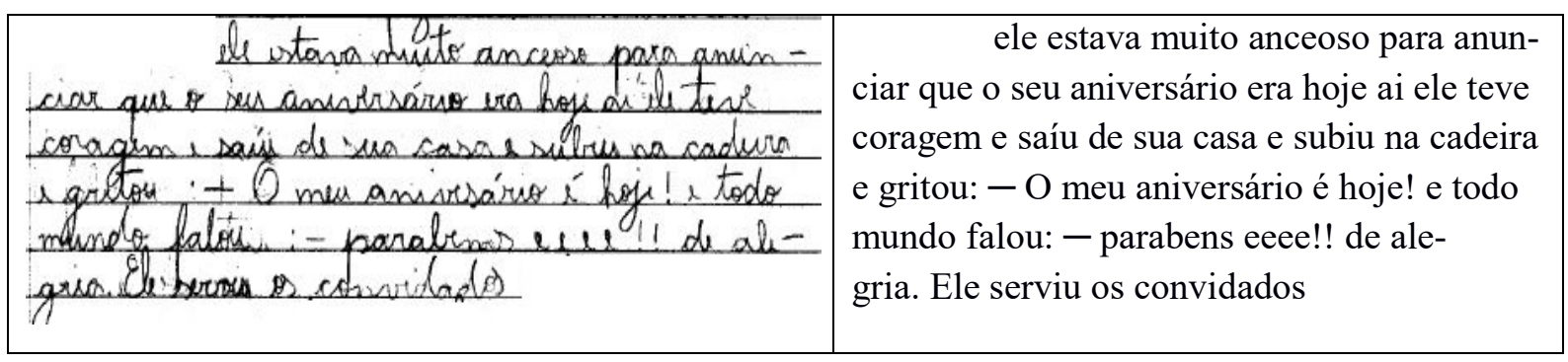

Fonte: manuscrito de pesquisa, coletado e transcrito pela autora, 2020.

O fragmento, como um todo, é recheado de oralidade: adoção de "aí" e repetição de "e" para indicar a sucessão dos fatos; uso seguido de pontos de exclamação; escolha por "eeee" para representar, o mais fielmente possível, a fala entusiasmada que teriam as personagens; e emprego reiterado de "ele" fazendo referência a Bilbo.

O diálogo, por sua vez, aproxima ainda mais o acontecimento do que poderia ser uma festa de aniversário bastante animada, porque é composta por um aniversariante ansioso e receptivo, ânimos alegres, saudações ao anfitrião e convidados bem servidos, aspectos comuns a muitas festas infantis.

No que diz respeito às supressões, em número de 59, as mais comuns foram: da conjunção subordinativa "quando", o que eliminou a relação temporal entre o anúncio da festa e a agitação dos moradores da Vila dos Hobbits; da data exata da comemoração, qual seja, "22 de setembro"; do sobrenome de Bilbo Bolseiro, possivelmente porque as crianças compartilhem de uma certa "intimidade" com o personagem uma vez que, ao longo do trimestre, trabalharam com a obra $O$ Hobbit (TOLKIEN, 2013), da qual ele é protagonista; e da expressão “de idade” em "Quando Bilbo Bolseiro anunciou que celebraria seus 111 anos de idade,...”, que fica subentendida no restante da oração.

Novamente, a substituição foi a operação mais realizada pelas crianças durante o exercício. Entre os 71 casos, recorrentes foram as vezes em que se substituiu o verbo "celebraria" pelas locuções verbais "ia celebrar", "ia comemorar", “ia fazer" e "queria comemorar". Nota-se uma preferência por tempos verbais compostos em detrimento dos simples.

Ademais, em algumas reescritas, a conjunção "quando" deu lugar às expressões "um dia" e "certa vez". A oração "houve muito comentário e agitação na Vila dos Hobbits", por sua vez, foi substituída por "teve muita animação", "a vila dos hobbits só falava disso", "foi uma festa entre os hobbits", "virou lenda", "todos ficaram muito ansiosos", "foi muita 
alegria" e derivados. As escolhas vocabulares praticadas dão a ver o movimento de aproximação da linguagem do texto à linguagem praticada cotidianamente pelas crianças, da qual se destaca a coloquialidade evidenciada, por exemplo, pelo uso dos verbos "ter" e "ser" no lugar de "haver".

A fim de comparar a ocorrência das operações sistemáticas da escritura entre os diferentes textos-fonte, observemos o quadro 9, a seguir, em que as colunas dos gráficos estão organizadas por ordem alfabética para maior conforto do leitor. 
Quadro 9: Ocorrência de operações sistemáticas da escritura nas quatro atividades propostas

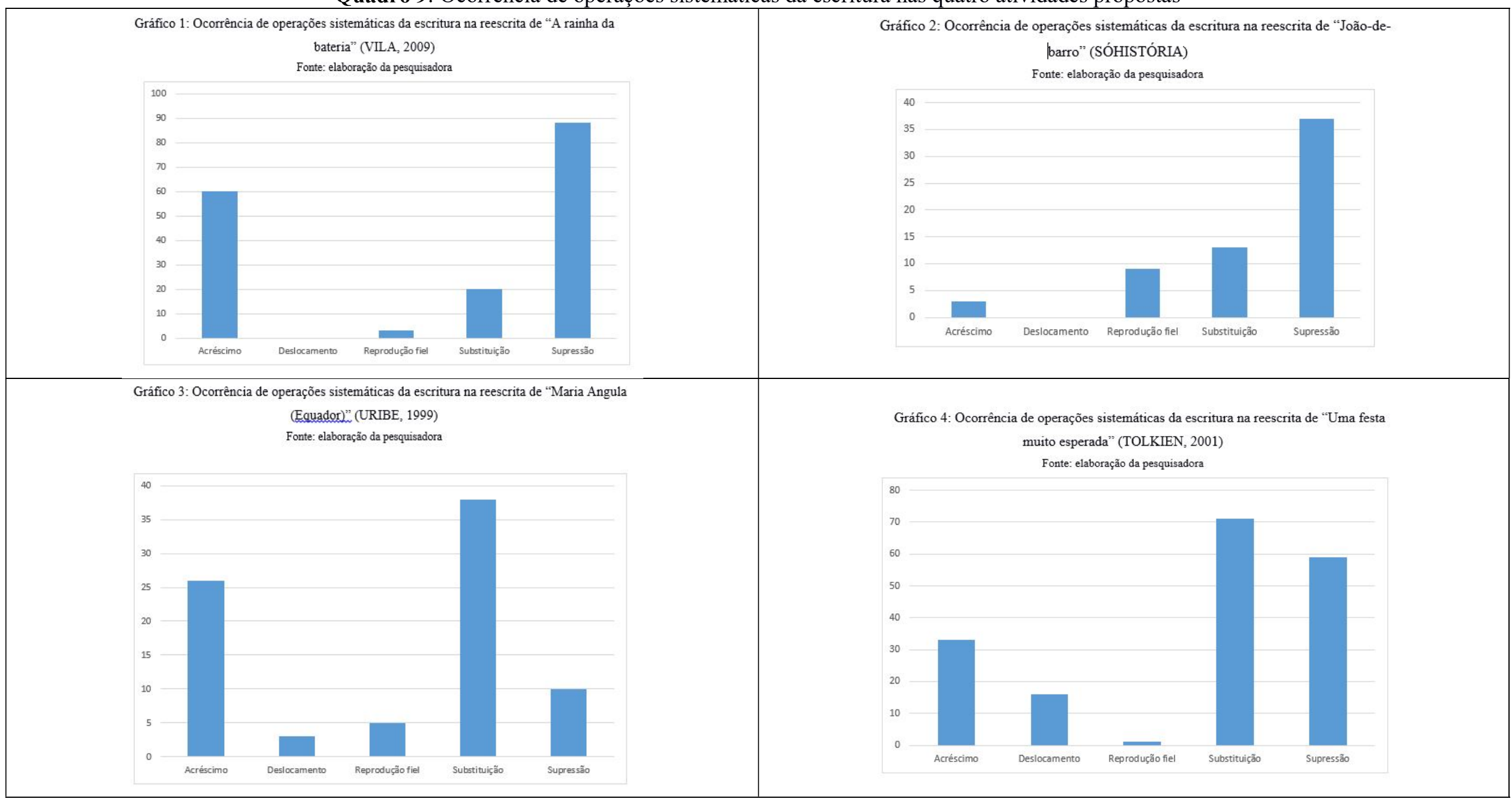

Fonte: elaborado pela autora, 2020. 
A partir da leitura dos gráficos, percebe-se que, na reescrita da frase de abertura dos textos-fonte utilizados nas quatro avaliações, houve prevalência de supressões (194) e substituições (142), seguidas pelos acréscimos (122). A ocorrência de deslocamentos (19) foi pequena, superando apenas o número de reproduções fiéis (18), das quais ocorreram exemplares em todas as quatro atividades. Assim, entre repetir exatamente o que leu e retomar de maneira diferenciada, as crianças tendem para o segundo movimento, dando vistas de que estão continuamente interpretando os textos dados a ler.

Como se nota, nas avaliações de fevereiro, agosto e novembro (gráficos 1, 3 e 4, respectivamente), o acréscimo acontece de maneira mediana. O texto-fonte utilizado na avaliação de abril (gráfico 2), no entanto, parece desfavorecê-lo, pois na sua reescrita a ocorrência da operação é visivelmente inferior.

Passando a olhar para os deslocamentos praticados pelas crianças durante o ano, percebe-se que, no início do processo, eles são inexistentes. Seu uso é inaugurado durante a reescrita do terceiro texto-fonte, quando ainda é pouco, e só se torna consistente no quarto exercício.

Igualmente, na pesquisa de Bezerra (2013), a operação de deslocamento foi aquela de menor número de ocorrências. Como sua hipótese explicativa pareceu-nos pertinente, partilhamos da mesma em relação à raridade desses episódios: a necessidade de maior habilidade do escritor para deslocar um segmento sem comprometer o sentido da escrita. Assim, acreditamos que o crescente número de deslocamentos efetuados pelos alunos explicase pela aquisição de algumas competências ao longo do ano, tais como a capacidade de hierarquizar informações de modo diferente do que fez o autor do texto original, associar ideias e identificar porções de texto passíveis de deslocamento.

Por requerer que um dado segmento não seja simplesmente acrescentado, eliminado ou substituído, mas transferido para outra parte do texto, o deslocamento foi, entre as operações sistemáticas da escritura, a menos realizada. Em número de casos, somente a reprodução fiel do texto-fonte perdeu para essa operação, tendo sido ligeiramente mais frequente nos trimestres do meio (abril e agosto).

Em fevereiro, a atividade aplicada teve caráter diagnóstico, isto é, precedeu as aulas e os exercícios de classe, o que poderia explicar o baixo número de reproduções fiéis, uma vez que as crianças não estavam ainda habituadas a esse comando de prova. Já na avaliação de novembro, acreditamos que a extensão e a complexidade da frase de abertura do texto-fonte, 
bem como o conhecimento que os alunos tinham dos elementos da história (evidenciado pelos acréscimos realizados), justifiquem a ocorrência de apenas um caso de reprodução fiel.

Passando às substituições e supressões, percebemos que as segundas dão lugar às primeiras entre abril e agosto. Se, na primeira e segunda avaliação, a supressão é a operação mais executada - o que talvez se explique pela falta de hábito das crianças em reproduzir, fielmente e de memória, extensas parcelas de texto -, no terceiro e quarto exercício, quando algumas estratégias já foram por elas desenvolvidas, sua ocorrência diminui e perde o posto para a operação de substituição.Ainda assim, a supressão não parece algo a ser explicado somente por maior ou menor competência linguística, pois sua ocorrência diminui do primeiro para o segundo trimestre e do segundo para o terceiro e aumenta consideravelmente do terceiro para o quarto trimestre.

Esses achados confirmam os de Bezerra (2013), em cuja pesquisa, que teve como participantes estudantes bem mais experientes do que os nossos, a substituição foi a operação mais utilizada. Bezerra (2013) interpretou essa tendência explicando que, na teoria em que as operações sistemáticas da escritura foram forjadas (a crítica genética), a operação de substituição é considerada a origem de todas as rasuras, pois, a partir dela, pode-se, com facilidade, efetuar mudanças ao escrever.

Por meio das quatro operações sistemáticas da escritura (GRÉSILLON; LABRAVE, 1983; GRÉSILLON, 2007), muitas vezes os participantes efetuam uma espécie de "atualização" do texto-fonte. Vários exemplos, além do que foi apresentado no quadro 8quando da reescrita de "Uma festa muito esperada" (TOLKIEN, 2001), poderiam ser mencionados nesse sentido.

No contexto de "A rainha da bateria" (VILA, 2009), chama a atenção um caso em que a criança registra, no momento de referir-se à justificativa dada pela mãe da protagonista para não levá-la à escola de samba, "meninada de rua" em vez de "meninada de morro", atualizando para a variante paulista a expressão adotada pelo autor carioca da versão original.

No caso de "João-de-barro" (SÓHISTÓRIA, 2019), por outro lado, há reescritas nas quais o pedido de casamento feito por Jaebé é direcionado à amada, não ao seu pai, em um diálogo que sequer existe no texto-fonte. Em um desses exemplares, a atualização vai além: em vez de o pretendente anterior a Jaebé ser desafiado a permanecer cinco dias em jejum, é preciso ainda que ele aguente não assistir à sua novela ao longo desse período.

Finalmente, no caso de "Maria Angula (Equador)" (URIBE, 1999), além de "atualizações" vocabulares, alterações na narrativa tornando-a mais verossímil para essas 
crianças também foram observadas. Um modelo é a reescrita em que a protagonista não se casa aos dezesseis anos, mas aos dezoito.

Todos esses são exemplos de que, mesmo em atividades cujo comando solicita a reescrita fiel dos textos lidos, não há o total esmagamento de uma autoria valiosa, aquela que resulta de uma demonstração, por parte do aluno, de sua própria visão. Embora na maior parte das vezes as crianças não pareçam ter como preocupação a transgressão das normas que lhes são impostas, não raro isso ocorre.

Para um avaliador, pode ser que as inovações representem uma não adequação, mesmo que pontual, da criança ao sistema de atividade proposto. Essa "reprovação" pode vir a significar um determinado grau de exclusão do grupo prestigiado, mas também evidencia um grau de autoria por parte do escrevente que, possivelmente, sequer enxergue o sentido prático das atividades de (re)escrita solicitadas. Ao redigir um texto autoral, cujo resultado pode ser o inconveniente de uma nota baixa, ele assume esse risco.

\section{4 "Chatas, ricas e mimadas": uma aposta na manifestação da autoria}

Nesta seção, partindo da constatação de que crianças de oito anos utilizam-se das quatro operações sistemáticas da escritura (GRÉSILLON; LABRAVE, 1983; GRÉSILLON, 2007) ao reescreverem textos de terceiros, introduzindo neles alguma alteração, selecionamos um manuscrito mais emblemático para ilustrar a dinâmica de reescrita de um texto completo por uma criança. Cumpre dizer que resultados preliminares da análise desse manuscrito foram anteriormente publicados por Riolfi e D’Alessandro (2019).

No contexto de produção de enunciados, concordamos com Orlandi (1996) sobre a necessidade de que o sujeito insira seu dizer no repetível para ser interpretável. Em outras palavras, para que seja possível atribuir sentido ao seu texto, o autor traz à tona outros textos recuperados pela memória e costura ao seu.

Do mesmo modo, por ocasião das produções textuais que analisamos, as crianças constituem seu enunciado no interior das repetições. Ou seja, além de interpretar o textofonte, os participantes garantem, através de retomadas, que seu texto seja, também, passível de interpretação. Para a construção do autor, essa inscrição faz-se fundamental. Isso quer dizer que o autor constitui-se não pela repetição como exercício mnemônico, em que reproduz enunciados que sequer fazem sentido para ele, mas pela repetição histórica (ORLANDI, 1996). 
Para compreendermos a dinâmica da reescrita de um texto completo por uma criança, vamos ater-nos em como uma menina, que chamaremos de R., reescreveu "A rainha da bateria" (VILA, 2009).

Previamente, é necessário informar dois aspectos. O primeiro é que uma versão original do texto pode ser encontrada no Anexo 1. Composto por 53 segmentos (parágrafos), o texto conta a história de Maria Luisa, uma jovem órfã de pai que, após ter enfrentado a oposição de sua mãe com relação às suas escolhas, reestruturou sua identidade ao encontrar sua vocação para ser rainha de bateria, casar-se e tornar-se mãe. É importante ressaltar que a narrativa toda gira em torno da realidade dos ensaios e dos desfiles de uma escola de samba carioca.

O segundo é que, como já ressaltado, no momento da escrita do texto, a criança tinha em mãos uma sequência de figuras que narrava, imageticamente, o encadeamento de fatos. Ela está reproduzida na figura 1, item 1.3.4 do presente texto.

Posto isso, os quadros 10e 11, na sequência, trazem, respectivamente, a reprodução do manuscrito de R. acompanhado de sua transcrição diplomática para maior conforto do leitor.

Quadro 10: Reescrita de "A rainha da bateria" produzida por R.

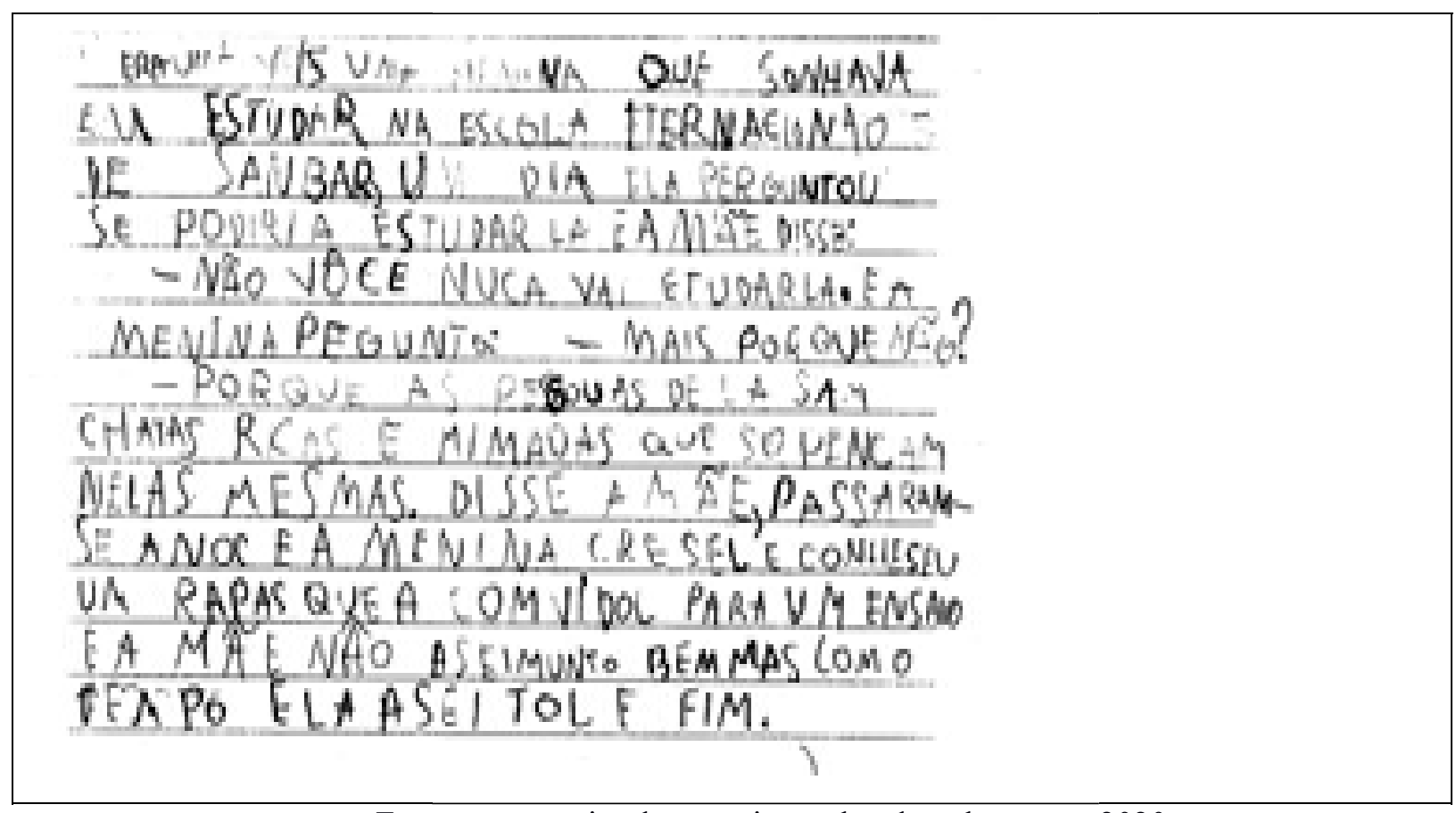

Fonte: manuscrito de pesquisa, coletado pela autora, 2020. 
Quadro 11: Transcrição diplomática da reescrita de "A rainha da bateria” produzida por R.

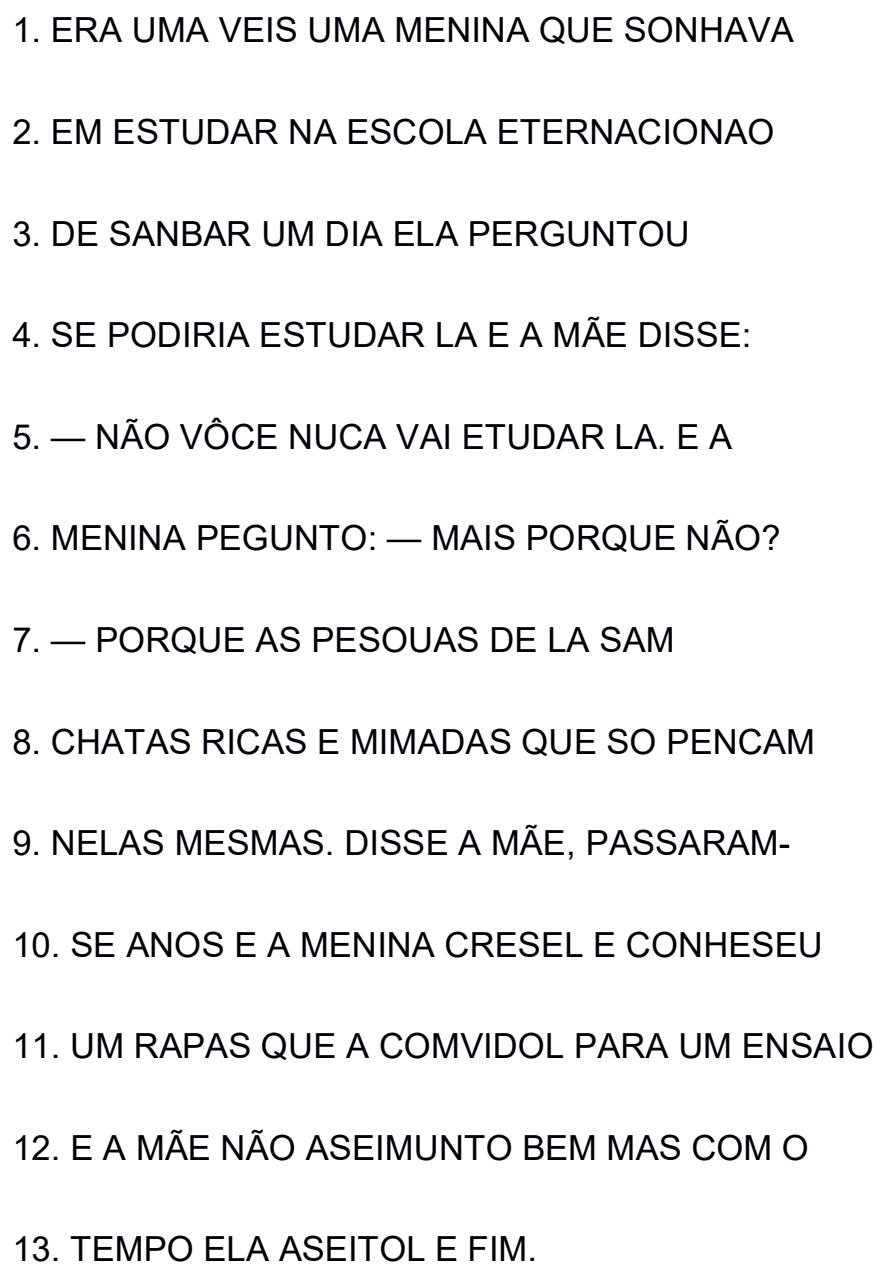

Fonte: elaborado pela autora, 2020.

Composto de 13 linhas manuscritas, o texto de R. apresenta, com relação ao textofonte, todas as operações sistemáticas da escritura. O primeiro aspecto a frisar é que sua reescrita deixa uma dúvida a respeito da compreensão, por parte de R., do que significa, no texto-fonte, "escola de samba". Se, lá, a expressão refere-se à agremiação de cunho popular que se reúne para cantar e dançar para fins competitivos, como veremos na sequência, seu texto deixa entrever que ela pode ter usado a expressão como "lugar onde se tem aulas para aprender a sambar".

As linhas 1 a 4 configuram um acréscimo, que vamos analisar na sequência. O quadro 12 , a seguir, mostra quais segmentos do texto-fonte foram restaurados por $\mathrm{R}$. 
Quadro 12: Segmentos do texto-fonte restaurados pela participante da pesquisa

\begin{tabular}{|l|c|}
\hline \multicolumn{1}{|c|}{ Excerto do texto-fonte } & Presença no texto de R. \\
\hline — Mãe, me leva lá na quadra? & Linhas 5 a 9 \\
— Põo. Lá não é lugar para você! mãe? Vejo sempre crianças indo \\
para lá. \\
— É meninada de morro, filhos de gente que \\
não presta. \\
\hline $\begin{array}{l}\text { Silas, um amigo de turma que era compositor } \\
\text { de uma grande escola de samba, rapaz } \\
\text { simples e muito cativante, educado e alegre, a } \\
\text { convidou para ir a um ensaio. Maria foi, } \\
\text { sambou muito e virou atração. Todos foram } \\
\text { muito gentis com ela. }\end{array}$ \\
\hline $\begin{array}{l}\text { Atualmente, ela desfila na frente dos ritmistas } \\
\text { como Rainha da Bateria e fotos dela são } \\
\text { publicadas em jornais, para orgulho da sua } \\
\text { mãe. É que dona Luzia perdeu o preconceito, } \\
\text { começou a gostar de samba e retomou a } \\
\text { alegria de viver, depois que a filha se casou } \\
\text { com Silas e eles tiveram uma filha linda. }\end{array}$
\end{tabular}

Fonte: elaborado pela autora, 2020.

Posto isso, por meio do cotejamento do texto reescrito por R. e a obra de Vila (2009), verificamos quais partes do texto fonte foram abandonadas na totalidade ou reduzidas aos seus elementos mínimos. Pudemos aferir que os seguintes itens foram ignorados pela criança:

1) Segmentos 1 a 4: Apresentação de Maria Luisa, jovem órfã de pai de quem herdou vasta cultura musical e gosto pela MPB;

2) Segmento 5: Introdução do conflito: em um sonho, o pai a instiga a frequentar escolas de samba, mas, na vida real, a mãe, apresentada como preconceituosa, rechaça essa possibilidade; 
3) Segmento 10: A boa impressão da protagonista com a realidade do ensaio em uma escola de samba;

4) Segmentos 11 a 18: As reiteradas fugas da protagonista para frequentar a escola de samba;

5) Segmentos 19 a 36: Recrudescimento dos conflitos com a mãe que, praticamente, faz da filha uma vítima de cárcere privado;

6) Segmento 37: A entrada para a vida universitária;

7) Segmentos 39 a 49: Experimentação de diversas posições na escola de samba até a aclamação como rainha de bateria;

8) Segmento 51: Descrição das posições assumidas na escola de samba pelas 3 mulheres da família na atualidade da história; e

9) Segmentos 52 e 53: Descrição do que é um bom desfile de escola de samba, digno do amor popular.

Ao analisar os grandes segmentos suprimidos pela criança, notamos que, em sua maioria, referem-se ao campo léxico do samba e da escola de samba. São exceções apenas os segmentos 5 e 6 . Essas supressões provavelmente indicam, por parte da criança, uma dificuldade de compreensão desse universo: o que seria uma vivência em quadra de escola de samba para uma menina moradora da zona oeste da capital paulista?

Essa hipótese é reforçada pelo acréscimo ocorrido nas linhas 1 a 4 do texto de R., excerto totalmente inexistente no texto-fonte: ERA UMA VEIS UMA MENINA QUE SONHAVA/ EM ESTUDAR NA ESCOLA ETERNACIONAO/DE SANBAR UM DIA ELA PERGUNTOU/SE PODIRIA ESTUDAR LA. Nesse excerto, percebe-se que uma protagonista não nomeada expressa seu desejo de "estudar" em uma "Escola Internacional de Samba", ao invés de solicitar que seja levada a uma quadra onde uma escola de samba estaria ensaiando para o desfile de carnaval.

É importante frisar que o livro de Martinho da Vila (2009) foi escrito em um contexto voltado a crianças cariocas, cuja realidade, muitas vezes, mescla-se com a do carnaval. Como esse não é o caso das crianças paulistas da região onde os dados foram coletados, talvez tivesse sido necessário discutir com as crianças o que, potencialmente, alguém vai fazer em uma "quadra" para que o texto-fonte fizesse maior sentido.

Mencionamos aqui ao menos duas possibilidades. A primeira é de que R. estaria ignorando a expressão "de samba" em "escola internacional de samba" e imaginando uma 
protagonista que desejava estudar em uma escola regular qualquer. Nesse caso, "de samba" seria apenas o nome da escola. A segunda é de que, distante da realidade de ensaios em quadras, R. pensa que samba se aprende em escolas de dança (a exemplo de escolas de ballet, de sapateado, de dança de salão etc.). Nesse segundo caso, teríamos uma restituição mais próxima do texto original, modificada, apenas, por uma lacuna de informação. Apostando na segunda hipótese, entendemos o ocorrido como sendo um desvio criativo (RIOLFI; BARZOTTO, 2011).

Como se lê no quadro 13, a seguir, as linhas 5 a 9 do texto da criança são a restituição dos segmentos 7 a 9 do texto-fonte.

Quadro 13: Cotejamento entre excerto do texto-fonte e sua reescrita

\begin{tabular}{|l|l|}
\hline \multicolumn{1}{|c|}{ Texto-fonte } & \multicolumn{1}{|c|}{ Reescrita de R. } \\
\hline 7. — Não. Lá não é lugar para você! & 5. — NÃO VÔCE NUCA VAI ETUDAR \\
8. — Por que, mãe? Vejo sempre crianças & LA. E A \\
indo para lá. & 6. MENINA PERGUNTO: - MAIS \\
9. — É meninada de morro, filhos de gente & PORQUE NÃO? \\
que não presta. & $\begin{array}{l}\text { 7. — PORQUE AS PESOUAS DE LA SAM } \\
\text { 8. CHATAS RICAS E MIMADAS QUE SO } \\
\end{array}$ \\
& PENCAM \\
& 9. NELAS MESMAS. DISSE A MÃE \\
\hline
\end{tabular}

Fonte: elaborado pela autora, 2020.

Analisando o quadro 13, percebemos a presença das quatro operações sistemáticas da escritura (GRÉSILLON; LABRAVE, 1983; GRÉSILLON, 2007). Por meio de sua utilização, a criança altera completamente os motivos que teriam levado a mãe da protagonista a negar o seu pedido. Se, no texto-fonte, ela expressa preconceito contra pessoas pobres ("meninada do morro"), no texto reescrito ela o faz a respeito das pessoas com alto poder aquisitivo ("pessoas ricas e mimadas que só pensam nelas mesmas"). Assim, a aluna deixa extravasar uma visão de mundo não convencional.

É possível que, por meio da voz da mãe da protagonista, R. esteja expondo o seu ponto de vista, revelando imagens e pressuposições. Ela pode estar manifestando, por exemplo, a visão que tem da escola frequentada pelas classes socialmente favorecidas (a escola 
internacional de samba): um ambiente elitista, barrado a personagens como Maria Luisa e a pessoas como R., aluna de escola pública.

Essa hipótese é reforçada pelo fato de que, no segmento final do texto reescrito, R. parece finalmente aceitar a perspectiva do texto-fonte, pois, após alguns anos, a protagonista do texto reescrito por ela conhece um rapaz que a convida para ir a um "ensaio" (linha 11), potencialmente de uma escola de samba. É como se, após ter contado a história que de fato desejava contar, R. tivesse assentido a voltar a efetuar o exercício solicitado em sua prova.

Nesse caso, embora, a princípio, possivelmente gerado por uma incompreensão de leitura, o excerto consistiria em um indício de autoria (POSSENTI, 2002a). Ele estaria marcado na possibilidade, por parte de R., de registrar, em seu texto, sua preferência com relação à classe social, oposta à expressa pela personagem mãe de Maria Luisa.

Ao renovar elementos de certa estabilidade, ainda que relativa, R. deixa de recorrer exclusivamente ao modelo fixo que lhe é apresentado, estratégia que minimizaria riscos. Ao contrário, ela os assume, revelando um rudimento de estilo (COSTA, 2016; 2019). Embora não se reduza a satisfazer seu avaliador, R. também não deixa de cumprir as "regras do jogo", ampliando as extremidades do que fora definido. 


\section{Os textos-fonte e os produtos deles advindos}

Neste capítulo, cujo objetivo é analisar as especificidades dos textos gerados por diferentes textos-fonte, vamos inventariar doze produções escritas originadas em cada uma das solicitações. O critério de sua seleção foi a aproximação maior ou menor com o textofonte. Nesse sentido, as primeiras redações tendem a aproximar-sedo texto-fonte e as últimas dão a ver aspectos mais autorais da reescrita pelos participantes. Cumpre dizer que resultados preliminares da análise de alguns dos manuscritos aqui apresentados foram anteriormente publicados em D’Alessandro (2019).

\subsection{Desafios de repertório em "A rainha da bateria"}

Iniciaremos a análise pelas reescritas do texto "A rainha da bateria" (VILA, 2009), elaboradas em fevereiro, das quais a primeira selecionada está reproduzida no quadro 14, a seguir, e assinada por A.

Quadro 14: Reescrita de "A rainha da bateria" produzida por A. e transcrita pela autora

\begin{tabular}{|c|c|}
\hline ARAINHA DA QATERIA & A RAINHA DA BATERIA \\
\hline 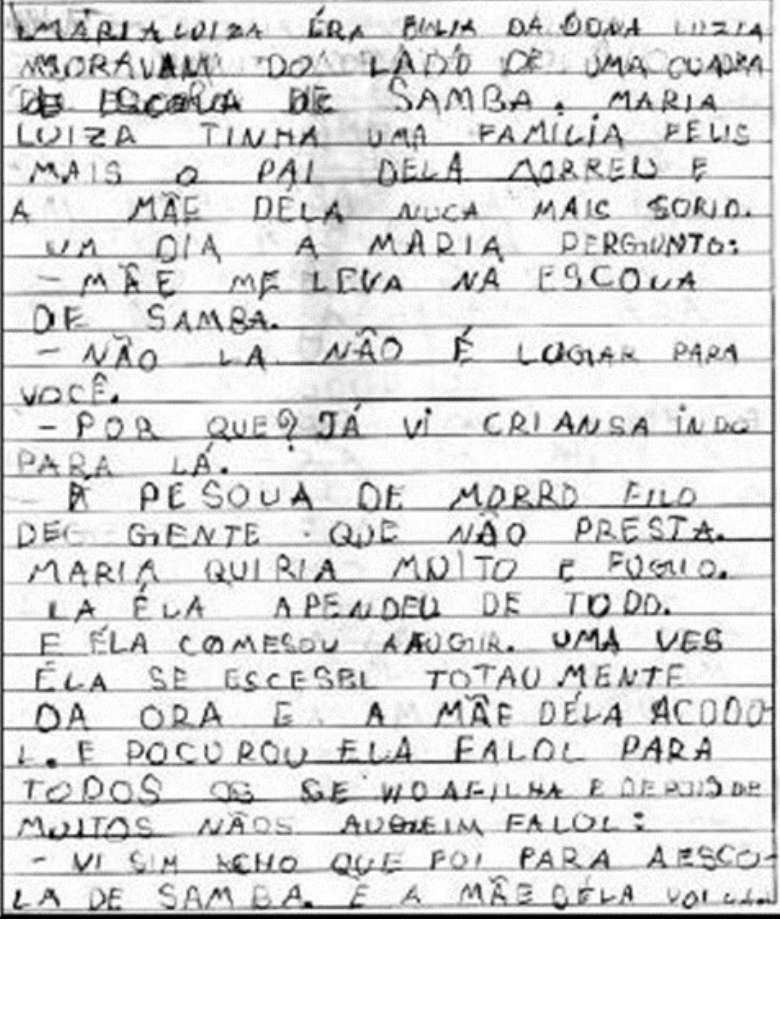 & $\begin{array}{l}1 \text { MARIA LUIZA ÉRA FILIA DA DONA LUZIA } \\
2 \text { MORAVAM DO LADO DE UMA CUADRA } \\
3 \text { DE ESCOLA DE SAMBA. MARIA } \\
4 \text { LUIZA TINHA UMA FAMILIA FELIS } \\
5 \text { MAIS O PAI DELA MORREU E } \\
6 \text { A MÃE DELA NUCA MAIS SORIO. } \\
7 \text { UM DIA A MARIA PERGUNTO: } \\
8 \text { - MÃE ME LEVA NA ESCOLA } \\
9 \text { DE SAMBA. } \\
10 \text { - NÃO LA NÃO É LUGAR PARA } \\
11 \text { VOCÊ. } \\
12 \text { - POR QUE? JÁ VI CRIANSA INDO } \\
13 \text { PARA LÁ. } \\
14 \text { É PESOUA DE MORRO FILO } \\
15 \text { DE GENTE QUE NÃO PRESTA. } \\
16 \text { MARIA QUIRIA MUITO E FUGIO. } \\
17 \text { LA ÉLA APENDEU DE TODO. } \\
18 \text { E ÉLA COMESOU A FUGIR. UMA VES } \\
19 \text { ÉLA SE ESCESEL TOTAUMENTE } \\
20 \text { DA ORA E A MÃE DÉLA ACODO- } \\
21 \text { L. E POCUROU ELA FALOL PARA } \\
22 \text { TODOS OS CE VIO A FILHA E DEPOIS DE } \\
23 \text { MUITOS NÃOS AUGUEIM FALOU: } \\
24 \text { - VI SIM ACHO QUE FOI PARA A ESCO- } \\
25 \text { LA DE SAMBA. E A MÃE DÉLA VOI } \\
26 \text { QUANDO ELA CHEGOU LA VIO SOA }\end{array}$ \\
\hline
\end{tabular}




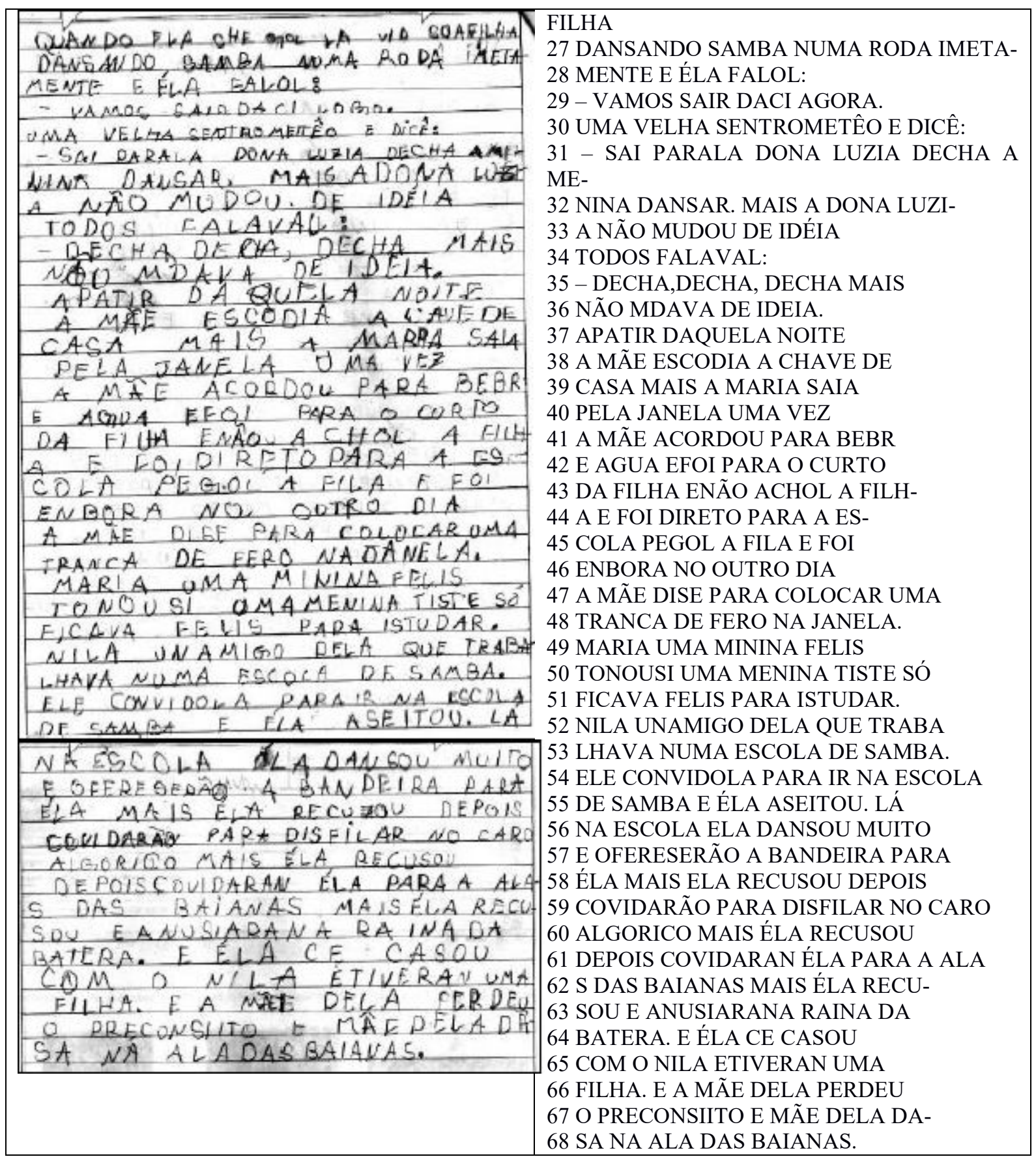

Fonte: manuscrito de pesquisa, coletado e transcrito pela autora, 2020.

O texto reproduzido no quadro 14 é composto por 68 linhas manuscritas. Seu título reproduz o do texto de Vila (2009). De modo geral, a leitura dá a ver que os elementos da narrativa presentes no texto original estão todos presentes: mãe viúva preconceituosa acusa a gente do morro de não prestar, e não quer deixar a filha Maria Luisa participar de ensaios de uma escola de samba; a moça casa-se e tem uma filha; o conflito termina com a mãe desfilando na ala das baianas. 
Contudo, logo no primeiro parágrafo, notam-se algumas diferenças entre o manuscrito da criança e o texto-fonte que norteou sua escrita, das quais é bom exemplo a supressão de informações como o gosto da protagonista pela música brasileira ("samba, chorinho, bossa nova, canção, calango, baião, xote...”) e a influência de seu pai, que inclusive lhe dera de presente um iPod com "discos dos nossos grandes artistas".

Imediatamente após a apresentação de Maria Luisa como sendo filha de dona Luzia, A. faz menção à proximidade entre a casa da protagonista e a escola de samba. O termo “subúrbio", por exemplo, presente na versão de Vila (2009), não aparece no texto do aluno.

Seguindo os moldes do texto-fonte, a sucessão dos fatos na reescrita de A. dá-se com a morte do pai de Maria Luisa e o impacto gerado por esse acontecimento na dinâmica da família. Apesar de suprimir diversos detalhes, como a diferença de idade entre o pai e a mãe da protagonista, A. não deixa de dizer que dona Luzia "nunca mais sorriu" (linha 6).

Já o sonho de Maria Luisa em que o pai a leva para assistir ao desfile de carnaval, motivador do pedido que ela faz à mãe, não aparece na produção do aluno. Mas, embora a expressão "cheia de preconceito" originalmente atribuída à dona Luzia também não exista na reescrita, o diálogo estabelecido pelas personagens no texto de A. é praticamente idêntico ao apresentado no texto de Vila (2009): "quadra" dá lugar a "escola de samba" (linhas 8 e 9) e "meninada" dá lugar a "pessoas" (linha 14), entre outras pequenas alterações.

A partir daí, as alternativas encontradas por Maria Luisa para sair de casa em direção à quadra, a procura e descoberta por parte de dona Luzia, as medidas que essa última toma para evitar a fuga da filha e a reação que a protagonista tem ao ser impedida de frequentar os ensaios são descritas pela criança com bastante fidelidade ao texto-fonte.

Apesar de não citar a "Faculdade de Comunicação" e a simplicidade, educação e alegria de Silas, que no seu texto é chamado de Nila, A. não deixa de mencionar, ainda que com escassez de detalhes, os convites feitos pelos líderes da escola de samba à Maria Luisa, que pronta e gentilmente os recusa até ser aclamada como rainha da bateria.

Finalmente, o casamento da protagonista e o nascimento de sua filha aparecem na reescrita do participante, bem como o orgulho de sua mãe, que abandona o preconceito e passa a desfilar na Ala das Baianas. Entretanto, os dois últimos parágrafos do texto-fonte, em que se diz da profusão de artes que caracteriza o desfile de samba e da paixão que muitas pessoas nutrem pelas escolas, são totalmente suprimidos quando da produção pela criança.

Ainda assim, trata-se de uma versão bastante próxima à obra de Martinho da Vila (2009), pois nela estão presentes os elementos principais da narrativa original. Vejamos, 
observando o quadro 15 a seguir, se o mesmo pode ser dito do manuscrito produzido por F. por ocasião da mesma atividade.

\begin{tabular}{|c|c|}
\hline A rainha da ba & $\mathrm{da}$ \\
\hline 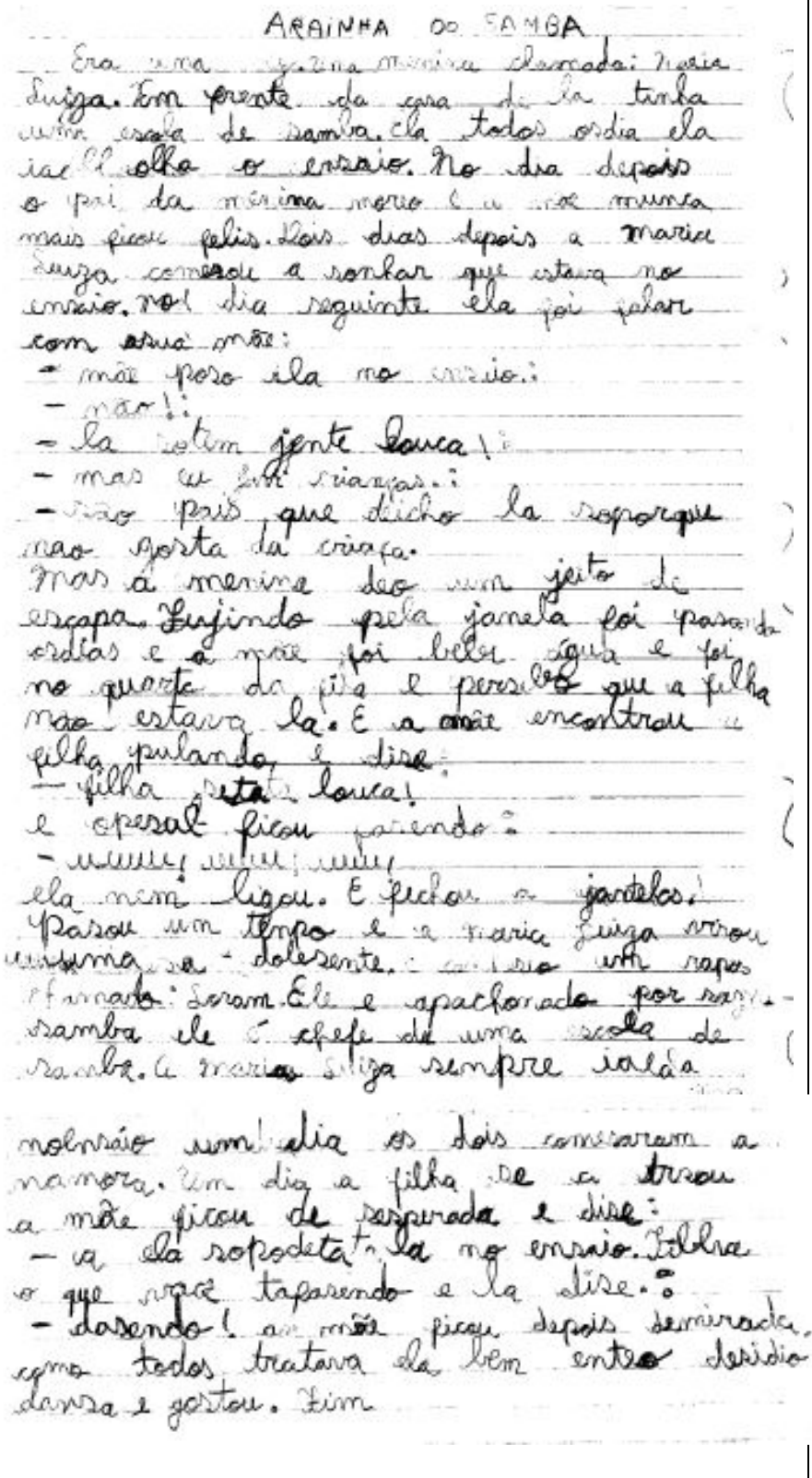 & $\begin{array}{l}\text { ARAINHA DO SAMBA } \\
1 \text { Era una vez una menina chamada: Maria } \\
2 \text { Luiza. Em frente da casa de la tinha } \\
3 \text { uma escola de samba. Ela todos osdia ela } \\
4 \text { iae olho o ensaio. No dia depois } \\
5 \text { o pai da minina morio e a mãe nunca } \\
6 \text { mais ficou felis. Dois dias depois a Maria } \\
7 \text { Luiza comesou a sonhar que estava no } \\
8 \text { ensaio. No dia seguinte ela foi falar } \\
9 \text { com asua mãe: } \\
10 \text { - mãe poso ila no ensaio.: } \\
11 \text { - não!: } \\
12 \text { - la sotem jente loucal: } \\
13 \text { - mas eu javi crianças.: } \\
14 \text { - são pais que deicho la soporque } \\
15 \text { nao gosta da criaça. } \\
16 \text { Mas a menina deo um jeito de } \\
17 \text { escapa Fujindo pela janela foi pasando } \\
18 \text { osdias e a mãe foi bebe água e foi } \\
19 \text { no quarto da fila e persebeo que a filha } \\
20 \text { não estava la. E a mãe encontrou a } \\
21 \text { filha pulando, e dise: } \\
22 \text { - filha sua louca! } \\
23 \text { e opesal ficou fasendo: } \\
24 \text { - uuuu! uuuu! uuu! } \\
25 \text { ela nem ligou. E fechou a janelas. } \\
26 \text { pasou um tenpo e a Maria Luiza virou } \\
27 \text { uma a dolesente. coneseo um rapas } \\
28 \text { chamado: Serane. Ele e apachonado por } \\
29 \text { samba ele é chefe de uma escola de } \\
30 \text { samba. A Maria Luiza senpre ialá } \\
31 \text { noensaio um dia os dois comesaram a } \\
32 \text { namora. Um dia a filha se a trsou } \\
33 \text { a mãe ficou de sesperada e dise: } \\
34 \text { - a ela sopodeta la no ensaio. Filha } \\
35 \text { o que você tafasendo e la dise: } \\
36 \text { - dasendo! a mãe ficou depois demirada } \\
37 \text { como todos tratava ela bem. enteo } \\
\text { desidio } \\
38 \text { dansa e gostou. Fim }\end{array}$ \\
\hline
\end{tabular}

Fonte: manuscrito de pesquisa, coletado e transcrito pela autora, 2020.

O texto reproduzido no quadro 15 é composto por 38 linhas manuscritas. Leva o título "A rainha do samba" e inicia-se com a expressão "era uma vez" (linha 1), muito comum em contos cujos leitores costumam ter a idade de F. Os elementos da narrativa presentes no texto original estão um pouco alterados: a mãe preconceituosa acusa a gente do morro de ser louca 
e não de não prestar; não há menção ao presente dado pelo falecido; o conflito termina com a mãe experimentando dançar, mas não se sabe qual é a dança.

$\mathrm{Na}$ versão da aluna, não são listados os gêneros musicais pelos quais Maria Luisa se interessava por influência de seu pai. O primeiro dado a seu respeito refere-se à proximidade entre sua casa e a escola de samba. Contudo, a referência à simplicidade da região em que mora a personagem, explicitada pelo termo "subúrbio" no texto-fonte, inexiste no manuscrito da participante.

Além disso, na versão da criança, são adicionadas informações cronológicas que não se fazem presentes no texto-fonte, evidenciadas pelas construções "no dia depois" (linha 4), “dois dias depois" (linha 6) e "no dia seguinte" (linha 8).

Após a morte do pai e a noite em que a protagonista sonha ser levada ao ensaio de uma escola de samba, que na versão original do conto é o próprio desfile de carnaval, há um diálogo entre Maria Luisa e sua mãe. No manuscrito da aluna, a fala dessas personagens é bastante diversa da que se encontra na obra de Vila (2009), conforme se nota pela observação do quadro 16, a seguir, através do qual se pode fazer o cotejamento entre o excerto de textofonte e sua reescrita.

\begin{tabular}{|l|l|}
\hline \multicolumn{2}{|c|}{ Quadro 16: Cotejamento entre excerto do texto-fonte e sua reescrita } \\
\hline \multicolumn{1}{|c|}{ Texto-fonte } & \multicolumn{1}{|c|}{ Reescrita de F. } \\
\hline - Mãe, me leva lá na quadra? & - mãe poso ila no enseio. \\
- Não. Lá não é lugar para você! & - não! \\
- Por que, mãe? Vejo sempre crianças indo & - la sotem jente louca! \\
para lá. & - mas eu javi crianças. \\
- É meninada de morro, filhos de gente que & - são pais que deicho la soporque não gosta \\
não presta. & da criaça. \\
\hline
\end{tabular}

Fonte: elaborado pela autora, 2020.

Na primeira fala de dona Luzia reproduzida pela aluna, a afirmação "Lá não é lugar para você!" é suprimida. Em vez disso, na história contada por F., a mãe afirma que no ensaio "só tem gente louca" (linha 12). Como no texto original, a protagonista argumenta com a mãe dizendo que crianças também costumam visitar a quadra, ao que a mãe finalmente responde que isso acontece não porque sejam pessoas "de morro", que "não prestam”, mas porque os pais não têm afeto por elas. 
Assim, analogamente ao que faz R. (cujo manuscrito foi objeto de estudo da seção 3.4 desta dissertação), F. parece expor o que, em sua visão, uma senhora preconceituosa poderia dizer a respeito dos frequentadores de uma escola de samba, com os quais não compactua e os quais deseja desqualificar: nada teria a ver com o lugar de habitação, mas sim com o abandono parental que exercem.

Embora o texto de F. seja bastante resumido em relação ao texto original, o restante dos fatos retratados é semelhante à obra de Vila (2009): Maria Luisa encontra meios de fugir, é descoberta, trancafiada, torna-se uma adolescente triste até que conhece um rapaz e volta a frequentar os ensaios, destacando-se e colaborando para que o preconceito de sua mãe seja superado. Na versão da criança, entretanto, não há menção ao casamento da protagonista, ao nascimento de sua filha e à diversidade própria de uma escola de samba, pela qual muitos se apaixonam.

Resta dizer que, na reescrita de F., o colega de Maria Luisa que a leva a visitar a quadra novamente, em vez de compositor, é "chefe de uma escola de samba” (linha 29), cargo que não parece existir na realidade. Acreditamos na possibilidade de que o repertório de algumas crianças dificulte a compreensão típica desse texto, em que há muitas referências, às vezes bastante específicas, ao universo carnavalesco. É o que parece ocorrer com R. (participante mencionada no capítulo 3) e com S., cujo manuscrito está reproduzido no quadro 17 , a seguir.

\begin{tabular}{|c|c|}
\hline $\mathbf{Q u}$ & \\
\hline 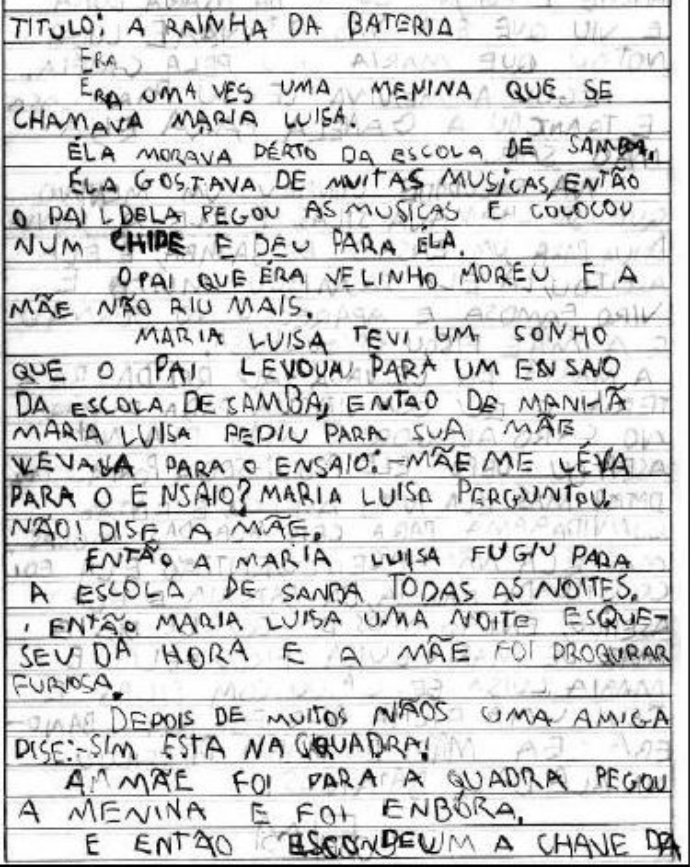 & $\begin{array}{l}\text { TITULO: A RAINHA DA BATERIA } \\
\text { ERA } \\
\text { 1ERA UMA VES UMA MENINA QUE SE } \\
2 \text { CHAMAVA MARIA LUISA. } \\
3 \text { ELA MORAVA PERTO DA ESCOLA DE SAMBA. } \\
4 \text { ELA GOSTAVA DE MUITAS MUSICAS, ENTÃO } \\
5 \text { O PAI L DELA PEGOU AS MUSICAS E COLOCOU } \\
6 \text { NUM CHIPE E DEU PARA ELA. } \\
7 \text { O PAI QUE ÉRA VELINHO MOREU E A } \\
8 \text { MÃE NÃO RIU MAIS. } \\
9 \text { MARIA LUISA TEVI UM SONHO } \\
10 \text { QUE O PAI LEVAVA PARA UM ENSAIO } \\
11 \text { DA ESCOLA DE SAMBA, ENTÃO DE MANHÃ } \\
12 \text { MARIA LUISA PEDIU PARA SUA MÃE } \\
13 \text { LEVALA PARA O ENSAIO: - MÃE ME LÉVA } \\
14 \text { PARA O ENSAIO? MARIA LUISA PERGUNTOU. } \\
15 \text { NÃO! DISE A MÃE. } \\
16 \text { ENTÃO A MARIA LUISA FUGIU PARA } \\
17 \text { A ESCOLA DE SAMBA TODAS AS NOITES. } \\
18 \text { ENTÃO MARIA LUISA UMA NOITE ESQUE- } \\
19 \text { SEU DA HORA E A MÃE FOI PROCURAR }\end{array}$ \\
\hline
\end{tabular}




\begin{tabular}{|c|c|}
\hline 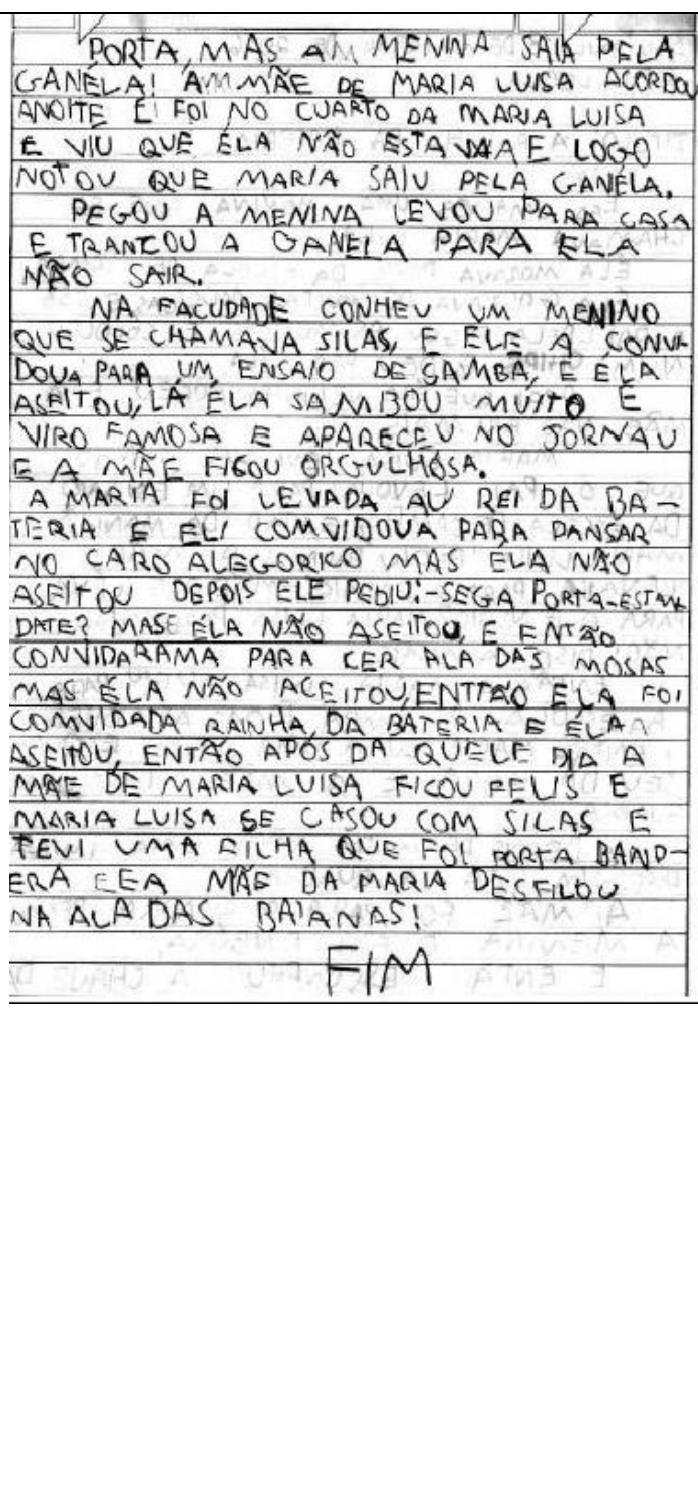 & $\begin{array}{l}20 \text { FURIOSA. } \\
21 \text { DEPOIS DE MUITOS NÃOS UMA AMIGA } \\
22 \text { DISSE: - SIM ESTA NA QUADRA! } \\
23 \text { A MÃE FOI PARA A QUADRA PEGOU } \\
24 \text { A MENINA E FOI ENBORA. } \\
25 \text { E ENTÃO ESCONDEU A CHAVA DA } \\
26 \text { PORTA MAS A MENINA SAIA PELA } \\
27 \text { GANELA! A MÃE DE MARIA LUISA ACORDOU } \\
28 \text { ANOITE E FOI NO CUARTO DA MARIA LUISA } \\
\text { 29 E VIU QUE ELA NÃO ESTAVA E LOGO } \\
30 \text { NOTOU QUE MARIA SAIU PELA GANELA. } \\
31 \text { PEGOU A MENINA LEVOU PARA CASA } \\
32 \text { E TRANCOU A GANELA PARA ELA } \\
33 \text { NÃO SAIR. } \\
34 \text { NA FACUDADE CONHEU UM MENINO } \\
35 \text { QUE SE CHAMAVA SILAS, E ELE A CONVI- } \\
36 \text { DOUA PARA UM ENSAIO DE SAMBA, E ELA } \\
37 \text { ASEITOU, LÁ ELA SAMBOU MUITO E } \\
38 \text { VIRO FAMOSA E APARECEU NO JORNAU } \\
39 \text { E A MÃE FICOU ORGULHOSA. } \\
40 \text { A MARIA FOI LEVADA AU REI DA BA- } \\
41 \text { TERIA E ELI COMVIDOUA PARA DANSAR } \\
42 \text { NO CARO ALEGORICO MAS ELA NÃO } \\
43 \text { ASEITOU DEPOIS ELE PEDIU: - SEGA PORTA- } \\
\text { ESTAN- } \\
44 \text { DATE? MAS ÉLA NÃO ASEITOU, E ENTÃO } \\
45 \text { CONVIDARAMA PARACER ALA DAS MOSAS } \\
46 \text { MAS ÉLA NÃO ACEITOU, ENTÃO ELA FOI } \\
\text { 47 COMVIDADA RAINHA DA BATERIA E ÉLA } \\
48 \text { ACEITOU, ENTÃO APÓS DA QUELE DIA A } \\
49 \text { MÃE DE MARIA LUISA FICOU FELIS E } \\
50 \text { MARIA LUISA SE CASOU COM SILAS E } \\
51 \text { TEVI UMA FILHA QUE FOI PORTA BAND- } \\
52 \text { ERA EA MÃE DA MARIA DESFILOU } \\
53 \text { NA ALA DAS BAIANAS! } \\
54 \\
55\end{array}$ \\
\hline
\end{tabular}

Fonte: manuscrito de pesquisa, coletado e transcrito pela autora, 2020.

Cumpre dizer que um excerto do texto reproduzido no quadro 17 foi exibido no quadro 3 (item 3.3) desta dissertação, como exemplo de uma operação de substituição. Composto por 55 linhas manuscritas, o manuscrito de S. é homônimo ao texto-fonte e, como o de F., inicia-se com a expressão “era uma vez" (linha 1).

Novamente, os elementos da narrativa presentes no texto original estão um pouco alterados: a mãe viúva não quer deixar a filha participar de ensaios de uma escola de samba, mas não se sabe o motivo, não há menção ao preconceito; sabe-se que Maria Luisa gostava de músicas, mas desconhece-se quais; a moça casa-se e tem uma filha; o conflito termina com a mãe desfilando na ala das baianas.

Mais uma vez, após revelar o nome da protagonista do conto, o narrador menciona que sua casa era vizinha à escola de samba. Das três reescritas reproduzidas aqui, porém, essa é a 
única que retoma o gosto de Maria Luisa pela música e o presente dado por seu pai, que, na versão original, tratava-se de um iPod e, aqui, trata-se de um “chip” (linha 6).

A morte do pai, que já era "velhinho" (linha 7), a tristeza de dona Luzia e o sonho que Maria Luisa tem são preservados por S.. No entanto, o diálogo que a personagem estabelece com sua mãe é significativamente mais curto na versão do aluno: após pedir para ser levada ao ensaio, a jovem ouve uma negativa e opta por não contestá-la.

Assim, passa a fugir todas as noites até ser descoberta pela mãe, que esconde a chave de casa. Escapando pela janela, a protagonista mais uma vez é pega e impedida de sair. Embora na narrativa de S. o sofrimento de Maria Luisa não seja mencionado, o encontro com Silas na faculdade acontece como na versão original do conto: ele a incentiva a voltar para a quadra, onde seu destaque é tamanho que a faz aparecer no jornal, encher de orgulho a mãe e ser levada ao "rei da bateria" (linha 40).

Dessa última reformulação, depreende-se que muitas das reescritas do texto de Vila (2009) parecem apresentar uma tendência à substituição vocabular, provavelmente devido à especificidade do assunto e dos termos que o autor adota em sua narrativa, talvez incomuns ao universo das crianças participantes.

Mais fiel ao texto-fonte do que F., S. descreve os convites feitos pelo então "rei da bateria", todos recusados por Maria Luisa, que acaba por tornar-se rainha, casar-se com Silas e ver sua família reunida desfilando.

Como em $100 \%$ das reescritas dessa obra, os dois últimos parágrafos da versão original estão ausentes. No presente caso, dão lugar ao aviso de que a história chegou ao "FIM".

\subsection{Retomadas literais em "João-de-barro"}

O segundo grupo de manuscritos selecionados resulta da reescrita de "João-de-barro" (SÓHISTÓRIA, 2019). Observemos o quadro 18, a seguir, em que está reproduzido o texto de C. 
Quadro 18: Reescrita de "João-de-barro" produzida por C. e transcrita pela autora

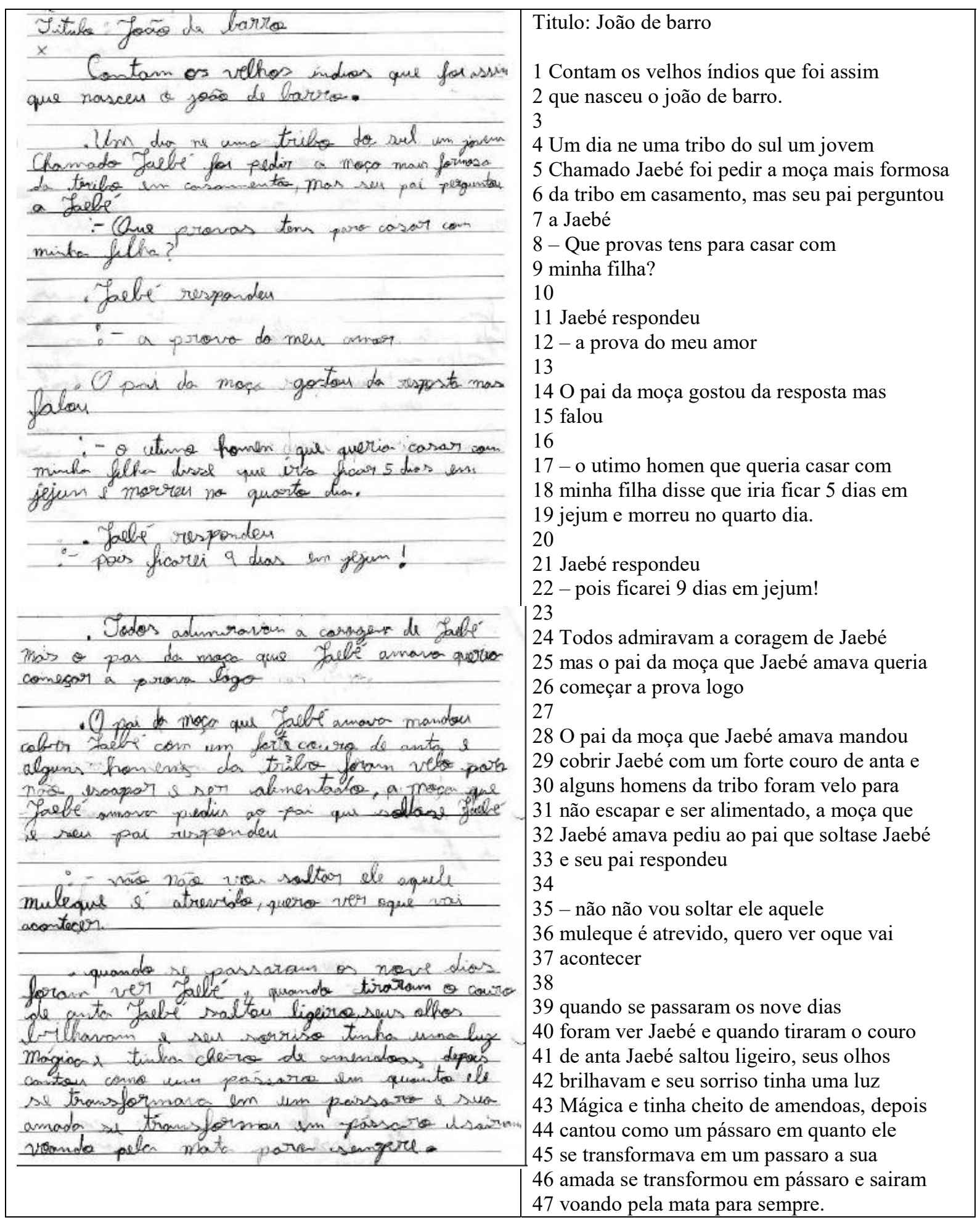

Fonte: manuscrito de pesquisa, coletado e transcrito pela autora, 2020.

O manuscrito, homônimo ao texto-fonte, é composto por 47 linhas. De maneira geral, ele guarda os elementos da narrativa original, quais sejam: existe uma frase de abertura atribuindo a autoria da narrativa aos índios, e não ao narrador do texto; um jovem valente que 
se dispõe a provar seu amor em troca da mão de uma jovem em casamento; um pai que, de maneira intransigente, não modera as provas impostas ao jovem; e uma saída mágica ao conflito, que transforma os dois jovens em um casal de pássaros.

A produção de C., não fosse pelo acréscimo de "velhos" (linha 1) e pela supressão de "pássaro", seria iniciada de modo idêntico ao que faz o autor do conto original. Além disso, a análise do manuscrito permite entrever que, embora o aspecto lendário da história não esteja mencionado no segundo parágrafo, a ambientação da narrativa e a sucessão dos fatos são fiéis à versão lida pelo aluno: em uma tribo do sul do país, um jovem chamado Jaebé apaixona-se por uma belíssima moça e decide pedi-la em casamento para o pai.

Na produção de C., o diálogo que se estabelece entre Jaebé e o futuro sogro muito se assemelha ao existente no texto-fonte, com exceção de que, aqui, não há ainda menção de que o pai da moça teria achado seu pretendente "atrevido".

Descrita e iniciada a prova, na versão de C., a jovem apaixonada não implora à deusa Lua que mantenha Jaebé vivo e, ao pedir ao pai que o liberte, ouve uma resposta em que Jaebé é chamado de "muleque atrevido" (linha 35) em vez de "arrogante" que "falou nas forças do amor".

$\mathrm{O}$ antepenúltimo e o penúltimo parágrafo do texto-fonte estão resumidos no último parágrafo do texto de C., que é menos detalhado. Contudo, em linhas gerais, o desfecho da história é o mesmo: após nove dias, Jaebé é liberto e transforma-se em um lindo pássaro, bem como sua amada, que o segue para a mata.

Acreditamos que a maior diferença entre o texto-fonte e o manuscrito da criança é a supressão, nesse último, do parágrafo final daquele, em que o narrador faz a constatação do grande amor que uniu os jovens, retratado no cuidado com que o joão-de-barro constrói sua casa e protege seus filhotes, dando provas de que a força de Jaebé foi maior do que a morte.

A atividade com o texto "João-de-barro" (SÓHISTÓRIA, 2019) foi aquela que rendeu maior número de reescritas fiéis da frase de abertura por parte dos alunos, conforme se pôde verificar pela análise dos gráficos contidos no quadro 9 (capítulo 3) desta dissertação. Possivelmente, isso se deva à extensão do texto-fonte, menor em relação aos demais, e à simplicidade do seu vocabulário se comparado, por exemplo, ao texto "A rainha da bateria", objeto de estudo do item anterior.

Vejamos se o manuscrito assinado por I. e reproduzido no quadro 19, a seguir, corrobora com nossa hipótese. 
Quadro 19: Reescrita de "João-de-barro" produzida por I. e transcrita pela autora।

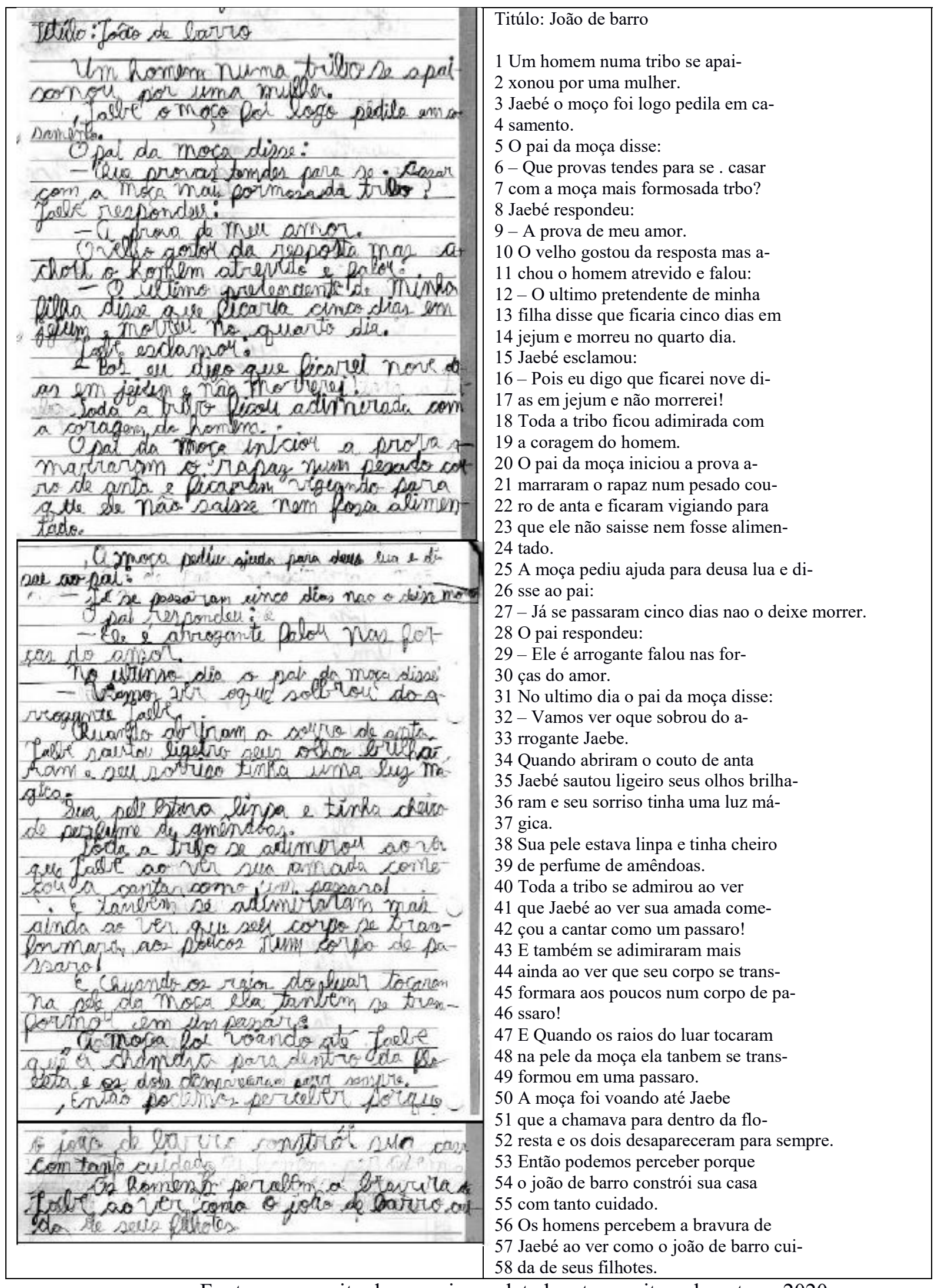

Fonte: manuscrito de pesquisa, coletado e transcrito pela autora, 2020. 
O manuscrito, de nome idêntico ao texto-fonte, é composto por 58 linhas. Alguns elementos gerais da narrativa original perderam-se, em especial, a frase de abertura atribuindo a autoria da narrativa aos índios, e não ao narrador do texto, e a localização da tribo onde a história teria acontecido (sul do Brasil). Do mesmo modo, não foi mencionado em qual pássaro os dois jovens foram transformados ao final da narrativa.

Embora não caracterize a amada de Jaebé como sendo uma moça de grande beleza, a segunda frase do texto de I. é muitíssimo semelhante à terceira frase do texto-fonte, da qual se diferencia apenas pelo acréscimo do advérbio "logo" (linha 3).

Quanto ao diálogo entre Jaebé e o pai da moça, podemos dizer que a retomada pela criança é bastante fiel à versão original da história. Notam-se, por exemplo, algumas substituições, como de "podes dar" por "tendes" (linha 6), de "jovem" por "homem" (linha 11) e de "disse" por "falou" (linha 11).

$\mathrm{Na}$ versão de I., a admiração da tribo diante da coragem do pretendente não é mencionada, mas a prova a que Jaebé é submetido é descrita como em SÓHISTÓRIA (2019). O trecho da reescrita em que a jovem apaixonada pede ao pai que solte Jaebé, por sua vez, é idêntico ao encontrado no texto-fonte, bem como a primeira frase da resposta dada pelo pai e, com exceção da substituição de "resta" por "sobrou" (linha 32), a fala desse ao ordenar que libertem o pretendente.

Os dois parágrafos seguintes da reescrita pelo aluno, em que é descrita a aparência de Jaebé quando terminada a prova, são, mais uma vez, idênticos ao texto-fonte. Os posteriores, embora não retomem de modo literal o texto-fonte, não deixam escapar nenhum detalhe: ao ver sua amada, Jaebé passa a cantar como um pássaro e a se transformar em um, bem como a jovem quando tocada pelos raios de sol o segue voando para a floresta e, com ele, desaparece para sempre.

Diferentemente do que faz C., I. resgata as palavras finais da versão original em seus dois últimos parágrafos, ao mencionar que a bravura de Jaebé se reflete na forma como o joão-de-barro constrói sua casa e cuida de seus filhotes, dando a ver uma proximidade ainda maior com o texto-fonte.

No quadro 20, a seguir, observemos a terceira reescrita selecionada de "João-de-barro" (SÓHISTÓRIA, 2019), produzida por P. 
Quadro 20: Reescrita de "João-de-barro" produzida por P. e transcrita pela autora

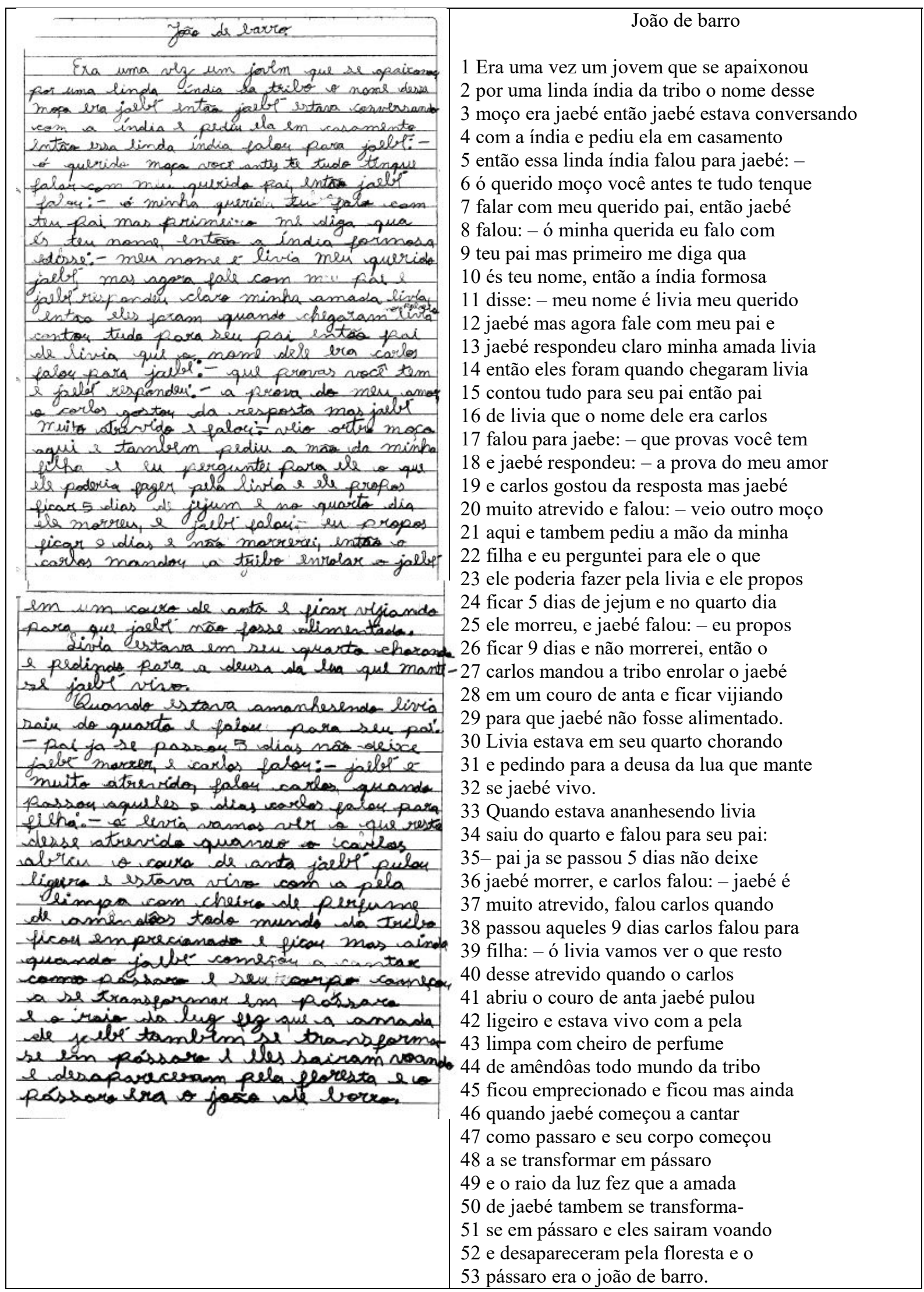

Fonte: manuscrito de pesquisa, coletado e transcrito pela autora, 2020. 
O manuscrito de P. é composto por 53 linhas. Seu título reproduz o de SÓHISTÓRIA (2019). De maneira geral, ele guarda os elementos da narrativa original, quais sejam: um jovem valente que se dispõe a provar seu amor em troca da mão em casamento de uma jovem; um pai que, de maneira intransigente, não modera as provas impostas ao jovem; e uma saída mágica ao conflito, que transforma os dois jovens em um casal de joão-de-barro. A diferença mais perceptível é a ausência da frase de abertura atribuindo a autoria da narrativa aos índios, e não ao narrador do texto, e o diálogo que se estabelece entre Jaebé e sua amada no início do texto da aluna.

A versão de P. inicia-se por “era uma vez", expressão comum entre as narrativas rotineiramente lidas por crianças como ela, e apresenta a amada de Jaebé como sendo uma índia de nome Lívia, elementos que não constavam no texto-fonte e foram, portanto, introduzidos pela participante.

Além disso, Jaebé não pede ao futuro sogro que lhe conceda a mão da moça em casamento, mas fala diretamente com ela, em uma espécie de "atualização" do texto-fonte para uma realidade que parece aproximar-se do universo da criança. A jovem é quem destaca a necessidade de que o pai autorize a união, ao que Jaebé responde afirmativamente solicitando que a moça lhe diga o seu nome antes. Tendo lhe dito que se chamava Livia, ela insiste para conversarem com seu pai sobre o casamento.

O pai, por sua vez, diferentemente do que ocorre no texto-fonte, tem um nome: Carlos. A atribuição de nome aos personagens mais uma vez assemelha a narrativa àquelas que as crianças comumente leem em sala de aula e fora dela.

O diálogo de Carlos com o pretendente, contudo, é bastante semelhante ao encontrado na versão original da história, bem como os acontecimentos que o sucedem: ele pergunta a Jaebé quais provas o jovem pode dar, ao que Jaebé responde tratar-se da prova de seu amor; Carlos gosta da resposta, mas considera o moço atrevido, então, menciona o pretendente que, tendo prometido ficar cinco dias em jejum, morre no quarto dia; Jaebé propõe ficar nove dias em jejum, é preso em um couro de anta e passa a ser vigiado; Livia pede à "deusa da lua" (linha 31) que mantenha Jaebé vivo e tem seu pedido de soltura negado pelo pai, que só liberta o rapaz no nono dia e assiste, como os demais, à transformação dele e da filha em um lindo casal de pássaros joão-de-barro.

Como fez C. e a maior parte das crianças participantes (quase $65 \%$ delas), P. suprime o parágrafo final do texto-fonte, em que o narrador constata que a prova do grande amor que 
uniu Jaebé e a bela moça, maior inclusive do que a morte, está no cuidado do pássaro com a casa e os filhotes.

\subsection{Apropriação do castigo em "Maria Angula (Equador)"}

O terceiro grupo de manuscritos selecionados resulta da reescrita de "Maria Angula (Equador)" (URIBE, 1999).

Muito comuns são as atividades em que se propõe a leitura de "Maria Angula (Equador)" (URIBE, 1999) durante as aulas de Língua Portuguesa no Ensino Fundamental I. A fim de comentar os usos diversos do conto equatoriano, fizemos um levantamento, no serviço de busca da internet Google, usando as combinações de palavras-chave "Maria Angula (Equador) exercício", "Maria Angula (Equador) atividade" e "Maria Angula (Equador) aula". Durante essa rápida pesquisa, nos foram sugeridos mais de sessenta endereços virtuais.

Acessando-os, descobrimos, basicamente, quatro tipos de exercícios propostos a diversos anos do Ensino Fundamental. São eles: a) exercícios em que, como acontece na avaliação a que nossos participantes de pesquisa foram submetidos, os alunos devem buscar informações contidas, implícita ou explicitamente, no texto, muitas vezes promovendo "copia e cola"; b) exercícios em que os alunos devem sistematizar sobre a forma (estrutura) do texto, familiarizando-se com o gênero conto; c) exercícios em que os alunos devem opinar sobre os acontecimentos da história; e d) exercícios em que os alunos devem produzir desenhos ou colagens relacionados à narrativa.

O mais notável, contudo, é que nenhuma das atividades envolve a discussão a respeito da origem do conto, com exceção de uma, contida no Portal do Professor, do MEC, em que, muito timidamente, antes de apresentar o texto aos alunos, sugere-se que o professor mencione tratar-se de uma história oral muito divulgada no Equador, país latino-americano. Esse é o máximo de aproximação a que se chega da origem da obra trabalhada.

Exceção à regra no trabalho com o conto equatoriano, o Caderno da Cidade adotado nas escolas municipais de São Paulo em 2019 continha, em seu volume 1 destinado à disciplina de Língua Portuguesa no sexto ano do Ensino Fundamental, uma introdução aos elementos da cultura equatoriana e, portanto, ao texto, além de um glossário, os quais se observam na figura 4 , a seguir. 
Figura4: Introdução à atividade com o texto "Maria Angula (Equador)" contida no Caderno da Cidade

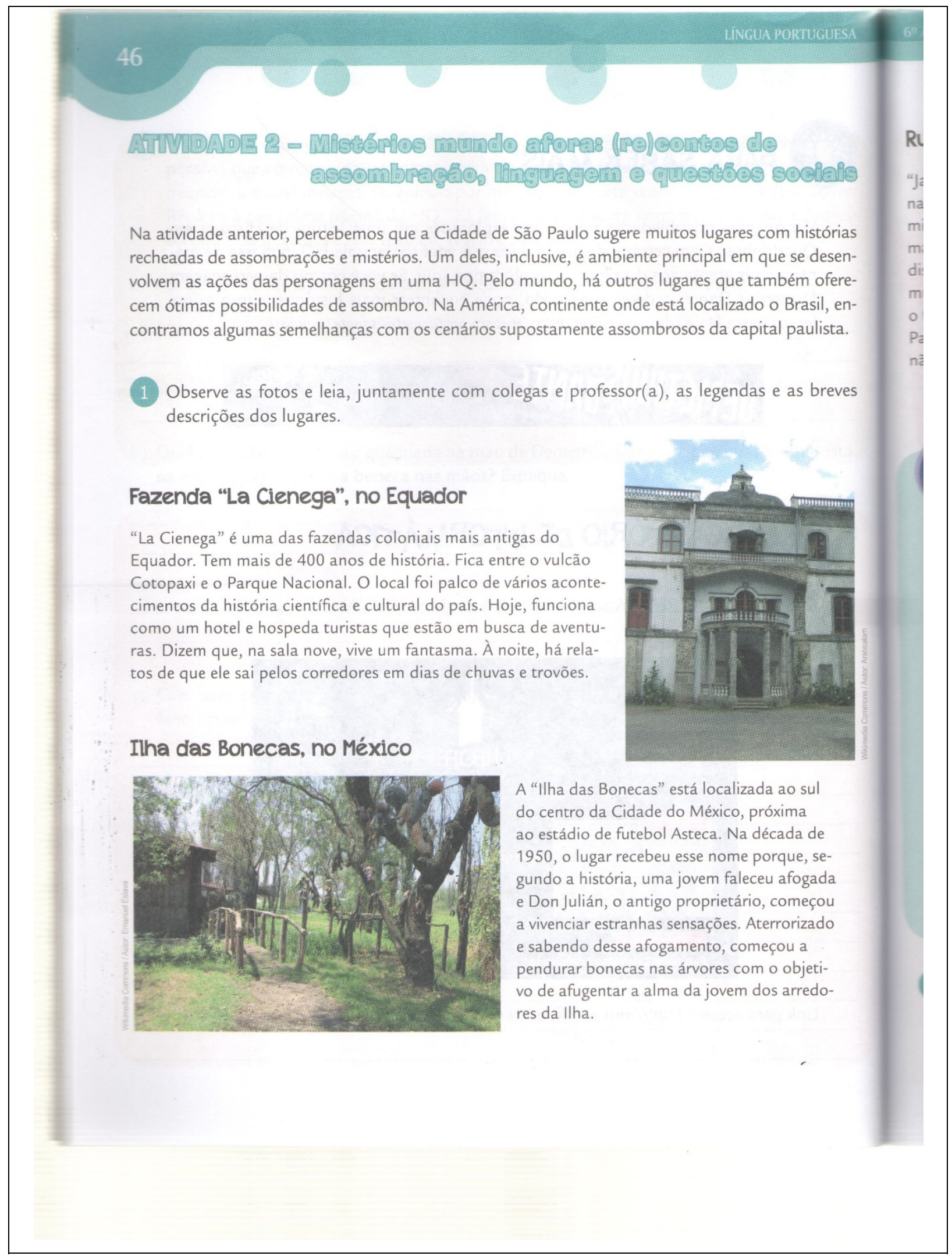



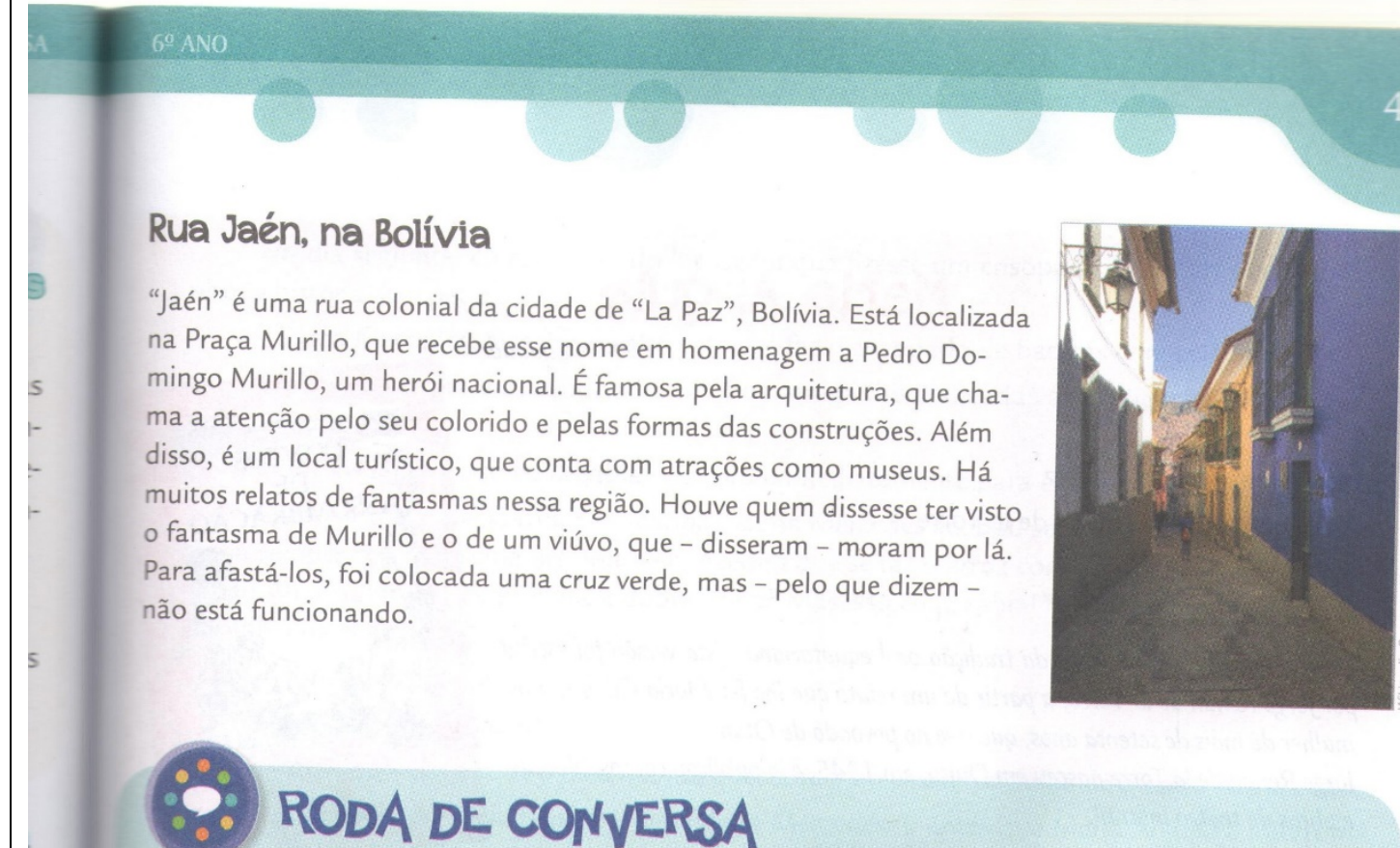

\section{RODA DE CONVERSA}

Converse com os(as) colegas e professor(a):

- Que impressões vocês tiveram das fotos e das breves descrições dos lugares?

- Em que medida as histórias de assombro e mistérios se parecem ou se distanciam daquelas que lemos a respeito de São Paulo?

- Por serem conhecidas no mundo todo, é possível que alguns de vocês já tenham visto ou ouvido histórias desses lugares: qual ou quais desconheciam?

- A Cidade de São Paulo recebe, diariamente, imigrantes e refugiados. Muitos deles(as) estudam na Rede Municipal de Ensino. Caso, em sua turma, tenham colegas nascidos(as) fora do Brasil, troquem experiências e conversem entre si sobre essas histórias de assompara trocar essas histórias misteriosas.

2 Agora, leia - juntamente com o(a) professor(a) - um conto de assombração chamado Maria Angula, que é muito popular no Equador: 


\section{Maria Angula}

Informante: Maria Gómez

Versão: Jorge Renán de la Torre

Maria Angula

"Maria Angula" é um conto da tradição oral equatoriana. Esta versão foi escrita por Jorge Renán de la Torre, a partir de um relato que Ihe fez Maria Gómez, uma mulher de mais de setenta anos, que vive no povoado de Otán.

Jorge Renán de la Torre nasceu em Quito, em 1945, e já publicou contos, fábulas e obras de teatro infantil.

Equador

\section{Glossário}

Colorau: condimento de cor vermelha, no caso deste conto, feito especificamente da semen-

te do urucum, como manda o costume equatoriano, mas que pode ser feito também à base de pimentão, e que serve,

sobretudo, para dar cor aos alimentos.

Fonte: Secretaria Municipal de Educação, 2018.

É considerada, portanto, a origem do conto no que precede o texto propriamente dito, em uma espécie de preparação para a obra que, mesmo quando destinada a crianças de 11 anos, pode soar como chocante. Mais do que isso, no exercício imediatamente posterior à leitura, os alunos são convocados a identificar, em trechos da história, elementos da cultura equatoriana que lhes foi apresentada pouco antes.

Questões relativas aos personagens, à estrutura do texto, à sua pontuação e ao gênero ao qual pertence são comuns nesse material. Muitas vezes, o conto parece estar a serviço da sistematização de conteúdos, como conjugação verbal e partes da narrativa, o que se pode observar na figura 5 , a seguir. 
Figura5: Sistematização de conteúdos durante atividade proposta pelo Caderno da Cidade

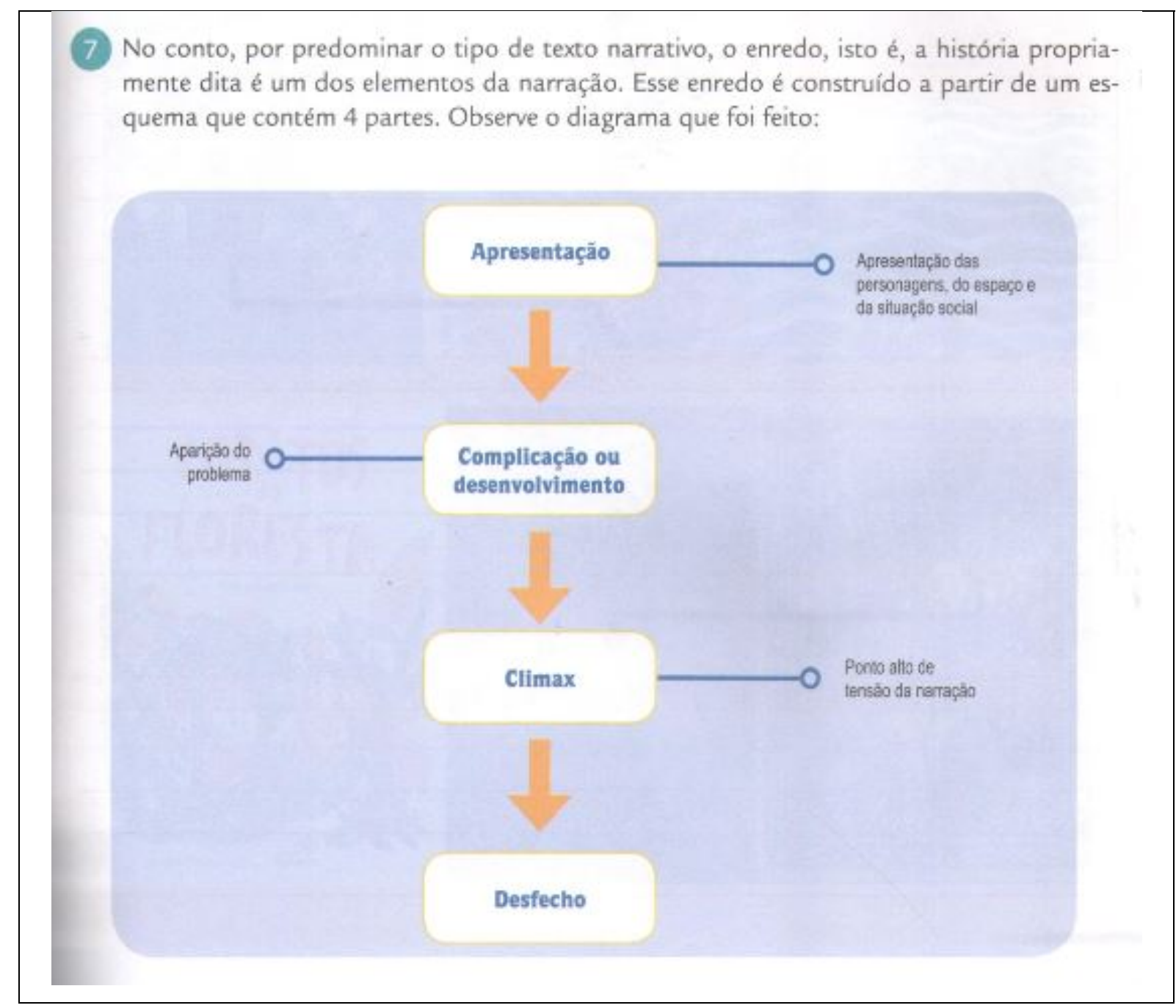


a) No caso do conto "Maria Angula", o desfecho é completamente diferente, pois não tem desfecho concluído. O final pode até ser considerado triste, mas é - sobretudo - misterioso. Com base no esquema da narração acima e no conto lido, complete o diagrama a seguir:

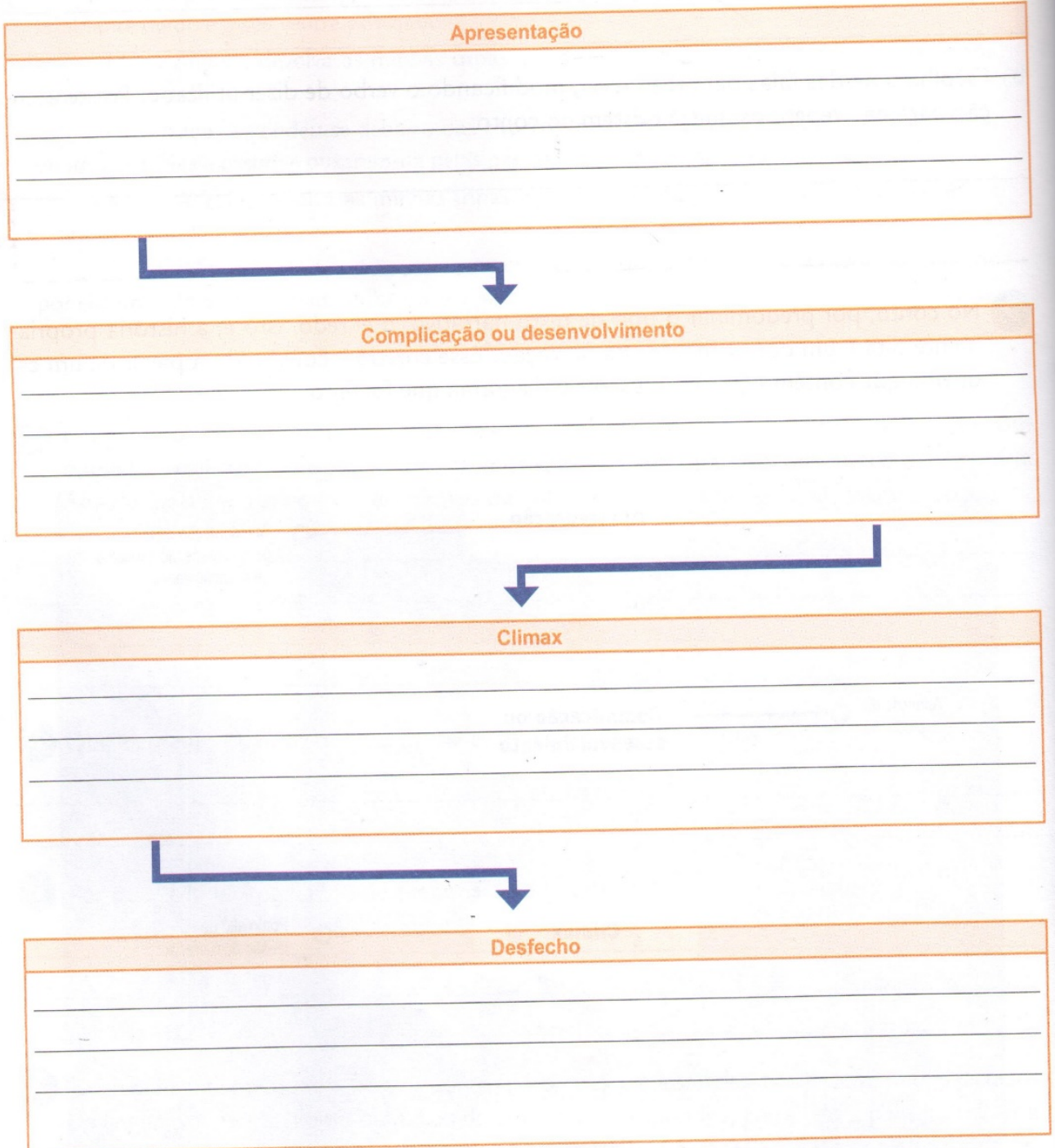

Fonte: Secretaria Municipal de Educação, 2018.

Em boxes, sugere-se que as crianças busquem outros enredos de mistério e assombração, dos quais bons exemplos o próprio livro oferece. 
Surpreendentemente, nas páginas finais da atividade, os estudantes são levados a refletir sobre os ensinamentos subjacentes ao conto. Nos itens que se seguem, são suscitados a pensar sobre o que dado texto, produzido em comunidade específica, diz a seu respeito. Nesse caso, a discussão central (e inédita até esse ponto de nossa investigação) é o papel da mulher, como se pode depreender da observação da figura 6 , a seguir, em que o item 8-b, a partir do termo "supostos", questiona o fato de configurar um problema (somente seu) Maria Angula não saber "cuidar da casa" e "preparar pratos saborosos".

Figura 6: Discussão proposta pelo Caderno da Cidade a partir da leitura de "Maria Angula (Equador)".

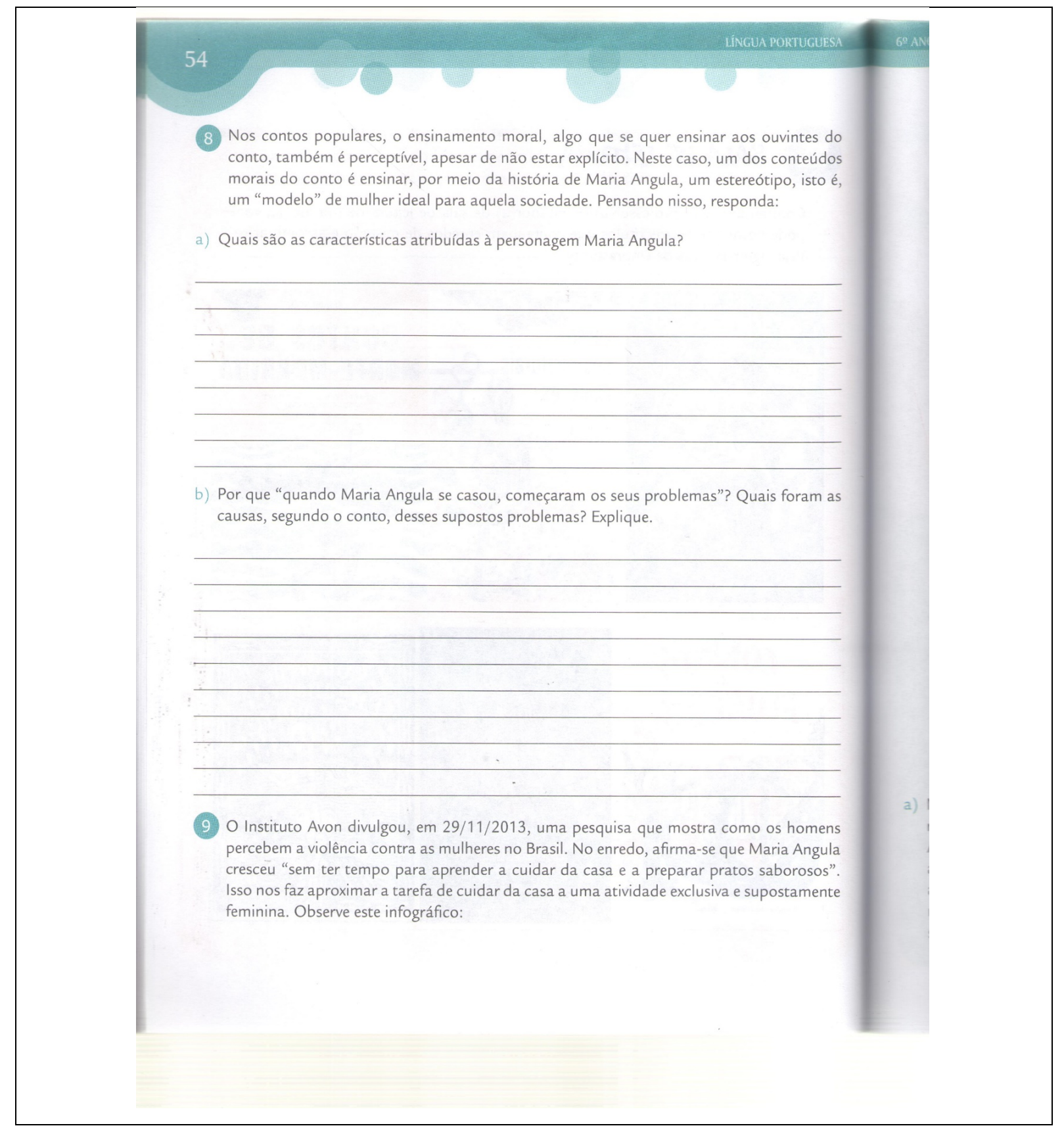




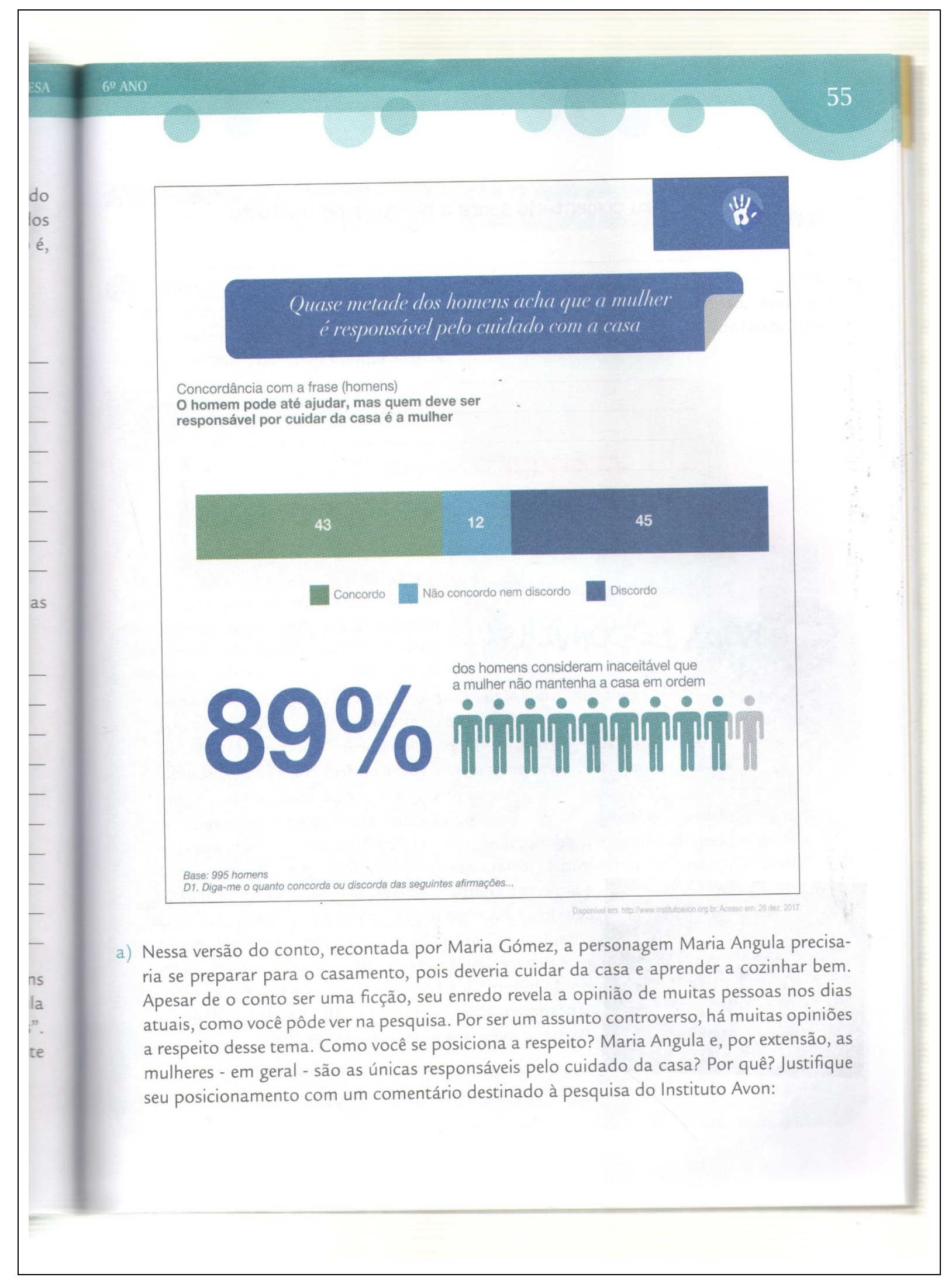




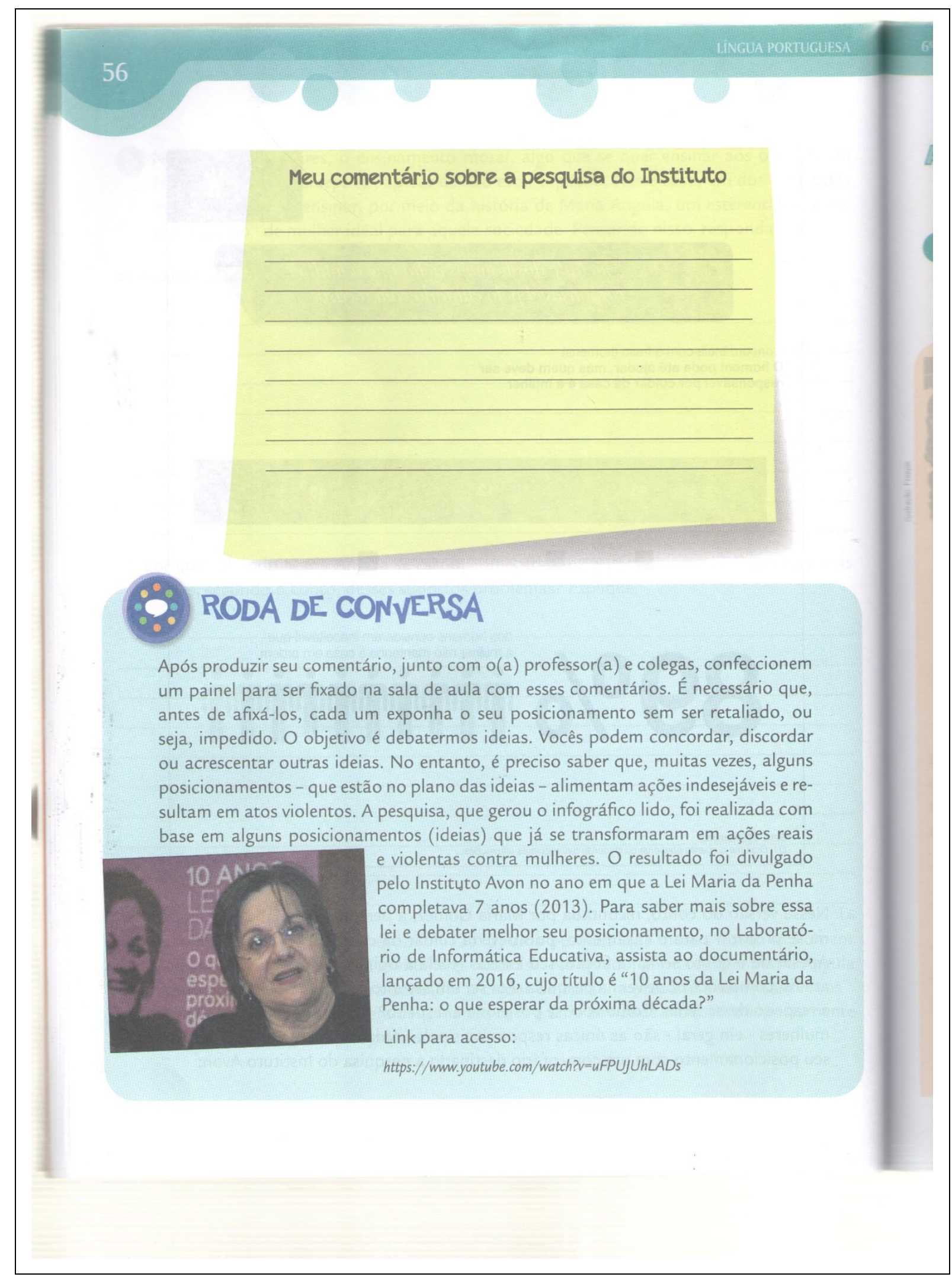

Fonte: Secretaria Municipal de Educação, 2018

Afinal, as crianças devem examinar dados, acessar repertórios e mobilizar argumentos de modo a se posicionar sobre um assunto que, se foi levantado graças à leitura do conto 
estrangeiro, agora diz respeito à comunidade na qual elas estão inseridas. Para além disso, devem discutir entre si sobre suas opiniões, registrando e coletivizando-as, sem desconsiderar as políticas públicas e as ações anti e pró violência decorrentes de debates como esse.

Retomando a análise dos textos resultantes da atividade proposta aos participantes de pesquisa em agosto, observemos o quadro 21, a seguir, em que está reproduzido o texto de G.

Quadro 21: Reescrita de "Maria Angula (Equador)" produzida por G. e transcrita pela autora

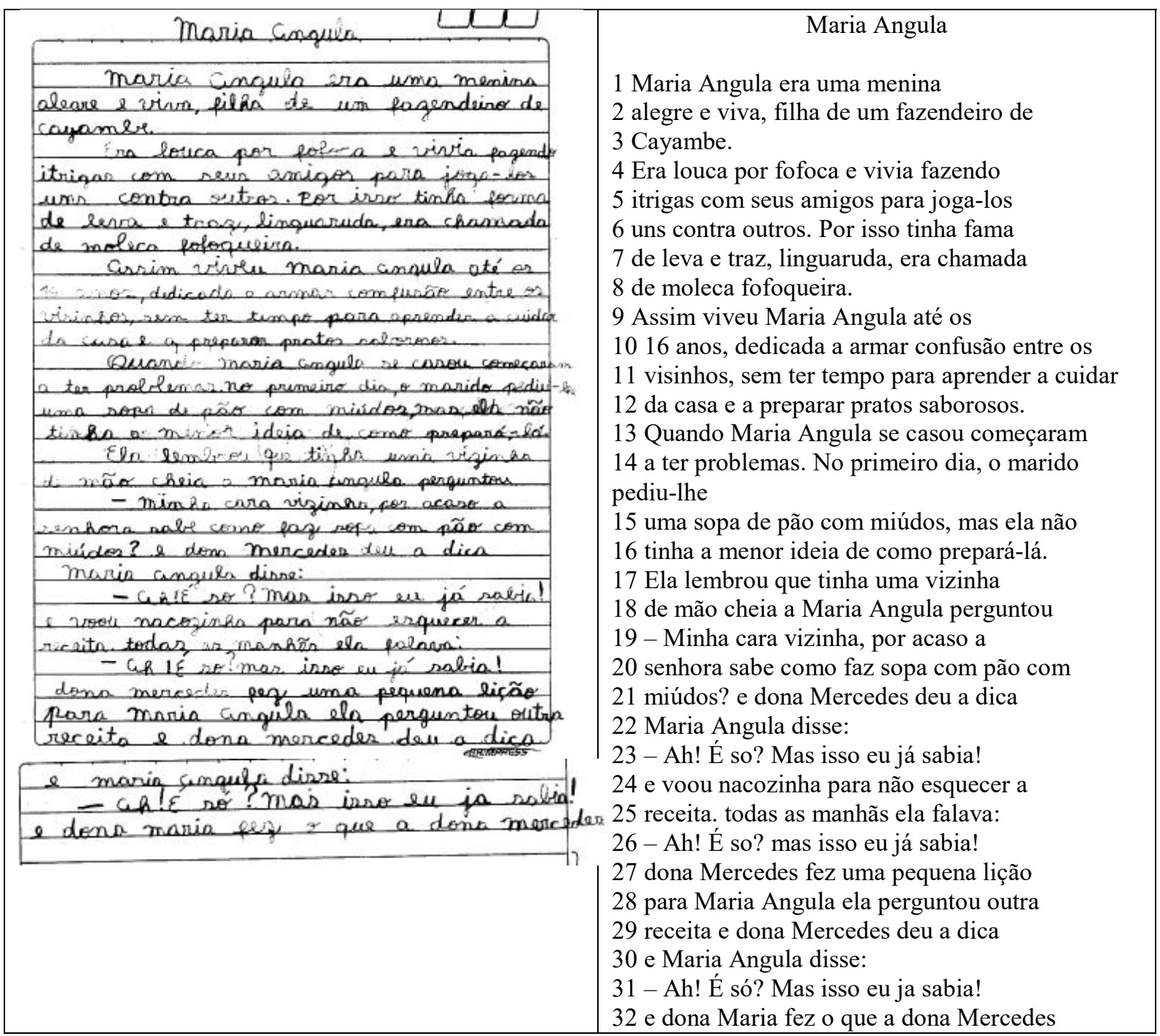

Fonte: manuscrito de pesquisa, coletado e transcrito pela autora, 2020.

O manuscrito de G. é composto por 32 linhas. Seu título reproduz apenas em partes o de Uribe (1999), pois apresenta o nome da protagonista (Maria Angula), mas não faz referência ao Equador, país de origem da história que não foi mencionado no texto-fonte, nem durante a execução da atividade pela professora e nem mesmo nos exercícios de interpretação textual que precederam a produção escrita pelos alunos. 
Seus quatro primeiros parágrafos são idênticos ao texto-fonte. Não sabemos se, de alguma forma, a aluna pôde consultar a versão original do conto. Nas frações de texto seguintes, G. faz cortes em relação à obra de Uribe (1999), tais como: a) da primeira tentativa fracassada de cozinhar feita pela personagem; b) das explicações detalhadas concedidas por Dona Marcedes que dão lugar a "dona Mercedes deu a dica” (linhas 21 e 29); e c) da menção aos pratos solicitados por Maria Angula. Ainda assim, a maior parte da escrita de G. reproduz ipsis litteris as frases do texto-fonte.

Chama a atenção, contudo, a não finalização do conto pela aluna, que parece interromper sua escrita no momento em que a protagonista seria alvo de uma armadilha feita pela vizinha (linha 32). Grampeado à redação, há um bilhete escrito manualmente, provavelmente pela professora, com os seguintes dizeres: "Não conseguiu terminar".

Arriscando-nos a imaginar o que pode ter acontecido com a aluna, nos parece que os esforços da criança em retomar o texto de modo literal, como solicitava o comando da atividade, lhe custou o tempo de avaliação e, portanto, o desfecho de sua história.

Comparemos as escolhas de G. com aquelas efetuadas por H., cujo texto encontra-se reproduzido no quadro 22 , a seguir. 
Quadro 22: Reescrita de "Maria Angula (Equador)" produzida por H. e transcrita pela autora

\begin{tabular}{|c|c|}
\hline 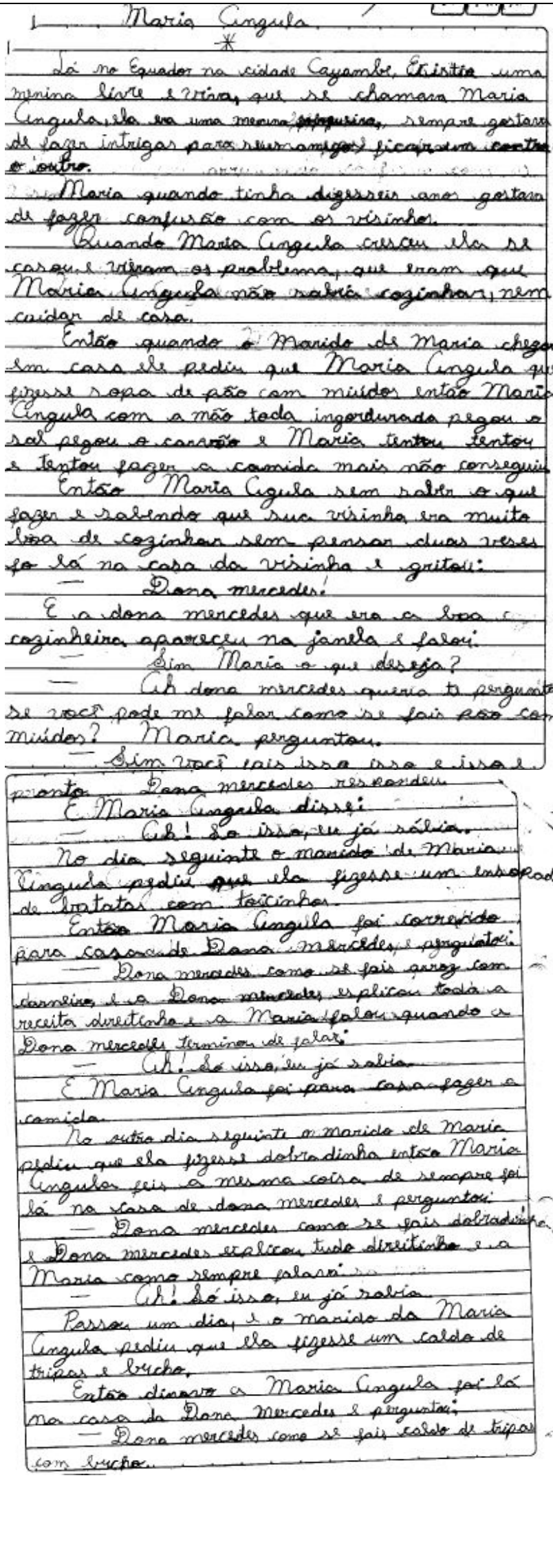 & 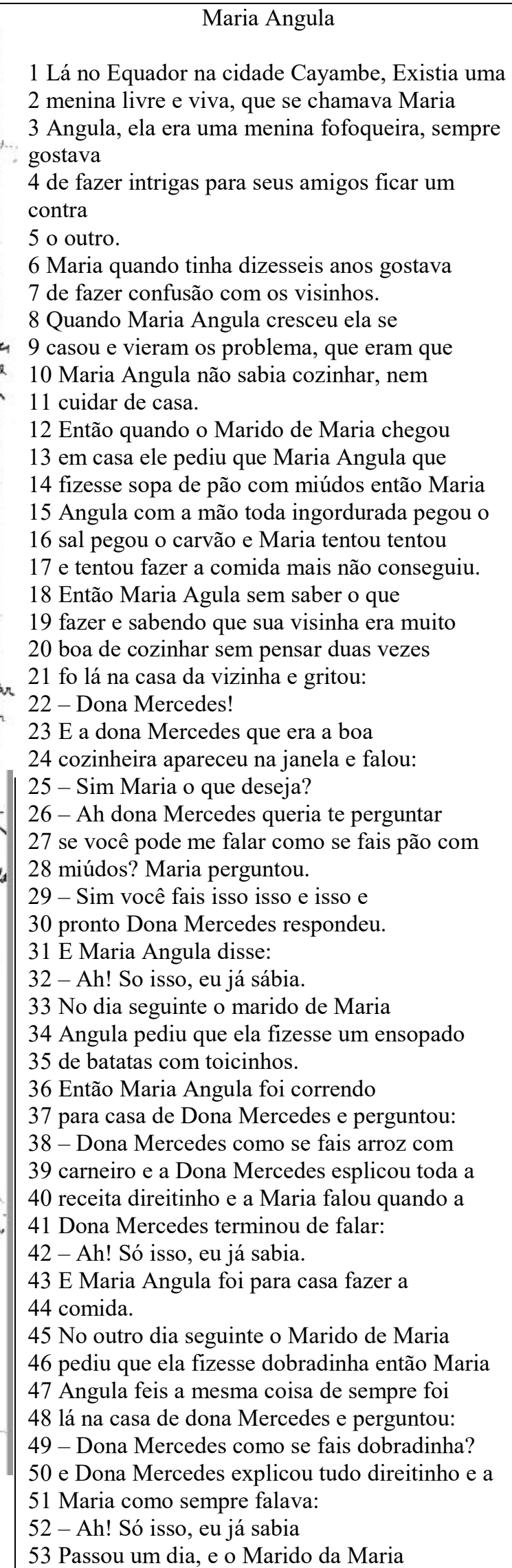 \\
\hline
\end{tabular}




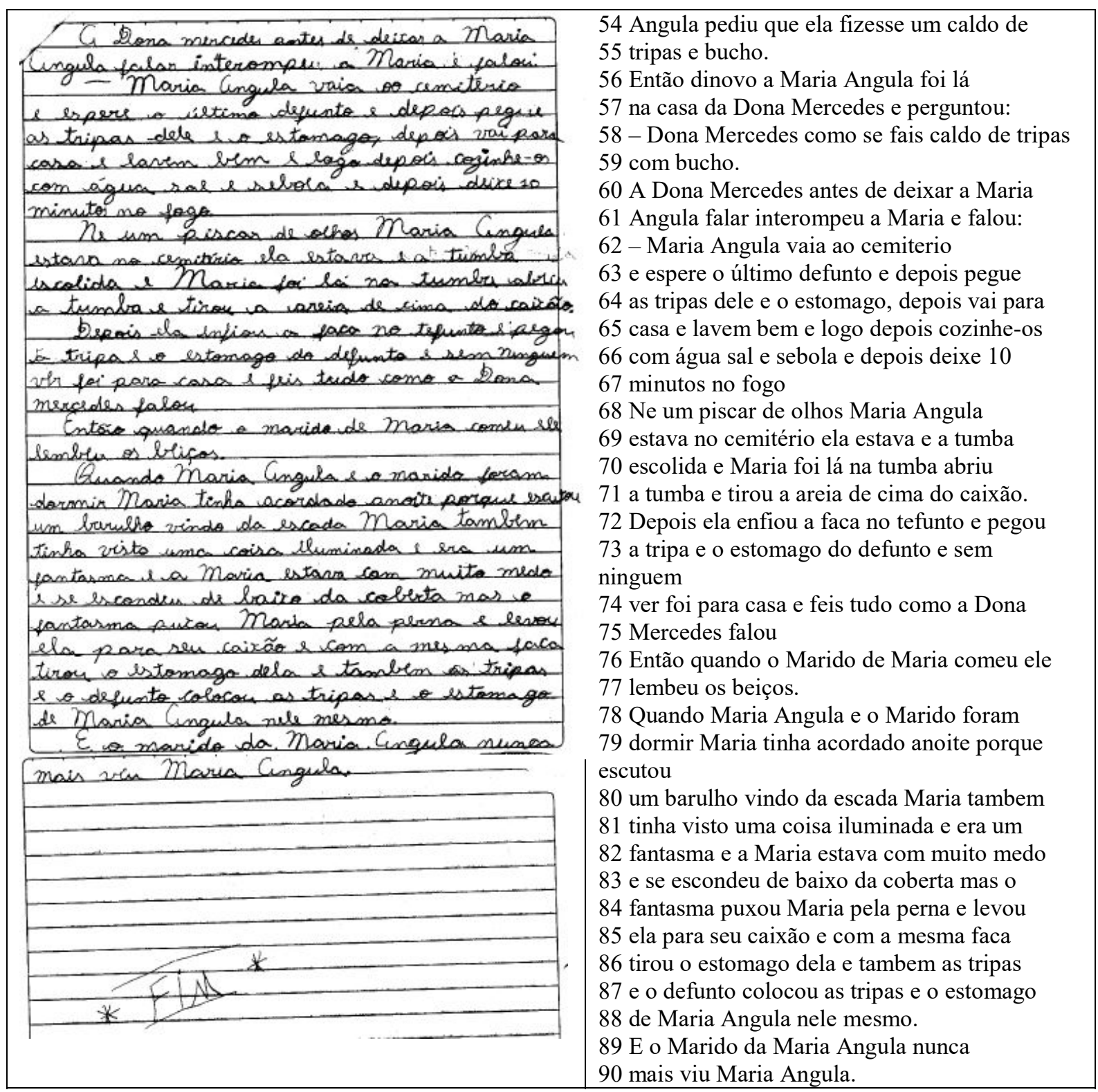

Fonte: manuscrito de pesquisa, coletado e transcrito pela autora, 2020.

O manuscrito de H. é composto por 90 linhas. Seu título não reproduz o de Uribe (1999) por não fazer referência ao Equador. Pode-se hipotetizar inicialmente que H. deu mais importância à protagonista da história, daí a supressão dos outros elementos, ou, ainda, que não compreendia a relevância de anotar o país de origem de uma narrativa.

A despeito dessa diferença, de maneira geral, ele guarda os elementos da narrativa original, quais sejam: uma jovem mulher de nome Maria Angula, dada à fofoca durante sua juventude, não aprende a realizar afazeres domésticos e, ao se casar, encontra problemas para cozinhar os pratos solicitados pelo marido; por isso, pede ajuda à vizinha que, cansada de sua ingratidão, resolve lhe pregar uma peça; Maria Angula, punida por seguir os conselhos da vizinha e violar um cadáver, nunca mais é vista pelo marido. 
Chama a atenção, logo na primeira linha da produção da aluna,a menção ao Equador, que não aparecera em seu título.Dissemos que a atividade não fora precedida de discussão a respeito dos temas suscitados pelo texto, nem mesmo sobre sua origem, o que, nos dias posteriores, também não aconteceu. Na própria narrativa original, o país só é citado no título.

Assim, nos parece que as práticas educativas observadas aproximam-se dos discursos oficiais (BNCC, 2017)que orientam a ação pedagógica a respeito de migrantes, imigrantes, refugiados, quilombolas, integrantes de comunidades rurais e assemelhados em termos de conteúdo, mas não de trabalho na sua abordagem.

Cumpre dizer que a atividade com o texto de Uribe (1999) foi a única, durante o período de recolha do corpus, em que os exercícios avaliativos (de interpretação e produção textual) tomaram como referência um conto de natureza não brasileira ou inglesa, mas equatoriano, isso é, originário de um país latino-americano multicultural e multilíngue cuja população indígena representa $25 \%$ do total de habitantes e constitui o centro das mobilizações em repúdio ao plano econômico neoliberal de um governo que, aliado em FMI, tenta lhe impor a lógica dos brancos.

Das quatro atividades avaliativas examinadas ao longo desta pesquisa, duas delas tomavam como texto-fonte contos brasileiros, quais sejam: "A rainha da bateria" (VILA, 2009) e "João-de-barro" (SÓHISTÓRIA, 2019), uma delas tomava como texto-fonte um conto equatoriano, objeto da presente seção, e a última tomava como texto-fonte um trecho de romance inglês $O$ Senhor dos Anéis (TOLKIEN, 2001), com o qual as crianças já vinham trabalhando em atividades rotineiramente aplicadas em sala.

As três primeiras, contudo, foram aplicadas de maneira idêntica, isto é, sem qualquer prévia que envolvesse introdução ao tema das narrativas. Ignora-se, portanto, o fato de que alunos brasileiros, como é o caso dos participantes, podem apresentar maior facilidade em retomar histórias relacionadas aos costumes de seu país do que histórias provenientes de outras regiões. $\mathrm{Na}$ ausência de um tratamento dado ao texto estrangeiro, tendem a adaptá-lo de acordo com os valores de sua comunidade.

No que concerne ao restante da reescrita, ela é bem semelhante ao texto-fonte, embora se observem, principalmente, algumas substituições, como de "alegre" por "livre" (linha 2) e de toda a explicação detalhada de dona Mercedes para a sopa de pão com miúdos por "você faz isso isso e isso e pronto" (linhas 29 e 30), e supressões, como do ímpeto de fugir do cemitério que, na versão da aluna, a protagonista não tem, das três facadas que, no textofonte, Maria Angula dá no morto e da repetida fala do defunto cobrando a devolução de suas 
tripas. Na versão de H., o fantasma retira as tripas e o estômago de Maria Angula e os coloca em si mesmo. Isso e o termo "fim" que encerra a produção são acréscimos em relação ao texto-fonte.

Observemos, finalmente, a terceira reescrita selecionada de "Maria Angula (Equador)", reproduzida no quadro 23, a seguir. O texto foi escrito por L.

Quadro 23: Reescrita de "Maria Angula (Equador)" produzida por L. e transcrita pela autora

\begin{tabular}{|c|c|}
\hline 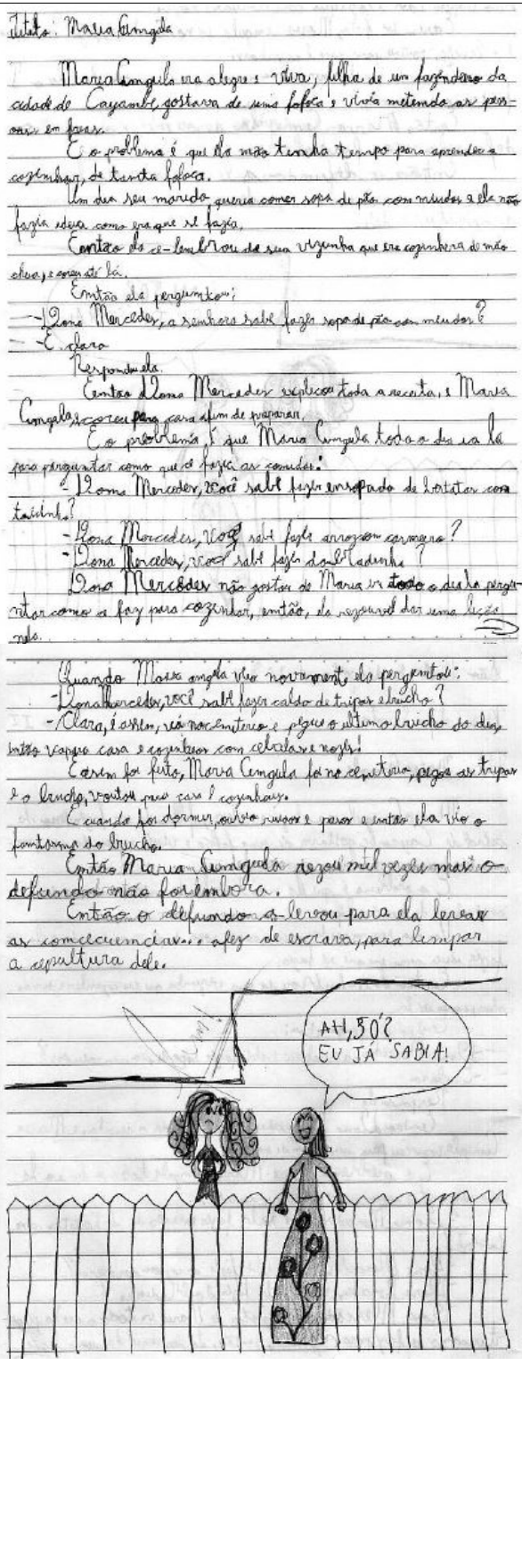 & $\begin{array}{l}\text { Titulo: Maria Angula } \\
1 \text { Maria Angula era alegre e viva, filha de um fazendeiro da } \\
2 \text { cidade de Cayambe gostava de uma fofoca e vivia metendo as } \\
\text { pess- } \\
3 \text { oas em frias. } \\
4 \text { E o problema que ela não tinha tempo para aprender a } \\
5 \text { cozinhar, de tanta fofoca. } \\
6 \text { Um dia seu marido queria comer sopa de pão com miudos e ela } \\
\text { não } \\
7 \text { fazia ideia como era que se fazia. } \\
8 \text { Então ela ce-lembrou de sua vizinha que era cozinhera de mão } \\
9 \text { cheia, e correu até lá. } \\
10 \text { Então ela perguntou: } \\
11 \text { - Dona Mercedes, a senhora sabe fazer sopa de pão com } \\
\text { miudos? } \\
12 \text { - E claro } \\
13 \text { Respondeu ela. } \\
14 \text { Então Dona Mercedes explicou toda a receita, e Maria } \\
15 \text { Angula coreu para casa afim de preparar. } \\
16 \text { E o problema é que Maria Angula todo o dia ia la } \\
17 \text { para perguntar como que ce fazia as comidas: } \\
18 \text { - Dona Mercedes, você sabe fazer ensopado de batatas com } \\
19 \text { toicinho? } \\
20 \text { - Dona Mercedes, você sabe fazer arrozcom carnero? } \\
21 \text { - Dona Mercedes, você sabe fazer dobradinha? } \\
22 \text { Dona Mercedes não gostou de Maria ir todo o dia la pergu- } \\
23 \text { ntar como ce faz para cozinhar, então, ela rezouvel dar uma } \\
\text { lição } \\
24 \text { nela. } \\
25 \text { Quando Maria angula veio novamente ela perguntou: } \\
26 \text { - Dona Mercedes, você sabe fazer caldo de tripas e bucho? } \\
27 \text { - Claro, é assim, vá nocemiterio e pegue o ultimo bucho do dia } \\
28 \text { então vapara casa e cozinheos com cebolas e nozes! } \\
29 \text { E asim foi feito. Maria Angula foi no cemiterio, pegou as } \\
\text { tripas } \\
30 \text { e o bucho, voutou para casa e cozinhou. } \\
31 \text { E cuando foi dormir, ouvio ruidos e pasos e então ela vio o } \\
32 \text { fantasma do bucho. } \\
33 \text { Então Maria Angula rezou mil vezes mas o } \\
34 \text { defundo não foi embora. } \\
35 \text { Então o defundo a levou para ela levar } \\
36 \text { as comcecuemcias... afez de escrava, para limpar } \\
37 \text { a cepultura dele. }\end{array}$ \\
\hline
\end{tabular}

Fonte: manuscrito de pesquisa, coletado e transcrito pela autora, 2020. 
O manuscrito de L. é composto por 37 linhas. Mais uma vez, seu título não reproduz o de Uribe (1999) por não fazer referência ao Equador.

De maneira geral, o texto guarda os elementos da narrativa original, quais sejam: uma jovem mulher de nome Maria Angula, dada à fofoca durante sua juventude, não aprende a realizar afazeres domésticos e, ao se casar, encontra problemas para cozinhar os pratos solicitados pelo marido; por isso, pede ajuda à vizinha que, cansada de sua ingratidão, resolve lhe pregar uma peça; Maria Angula, após seguir os conselhos da vizinha e violar um cadáver, é visitada pelo fantasma do morto.

Contudo, logo no primeiro parágrafo da produção da aluna notam-se as primeiras diferenças em relação ao texto-fonte: "vivia fazendo intrigas com os amigos para jogá-los uns contra os outros" dá lugar a "vivia metendo as pessoas em frias" (linhas 2 e 3). Além disso, a versão da criança não faz menção ao casamento da personagem aos dezesseis anos e nem à sua tentativa de preparar o primeiro prato requisitado pelo marido.

Outra substituição empreendida por L. é da explicação de dona Mercedes para o preparo da sopa de pão com miúdos. Nesse sentido, "É assim: primeiro coloca-se o pão de molho em uma xícara de leite, depois despeja-se este pão na panela e, antes que ferva, acrescentam-se os miúdos" dá lugar a "Então Dona Mercedes explicou toda a receita" (linha 14).

Porém, entre as maiores modificações propostas pela aluna, está a total supressão da resposta que, na versão original do conto, Maria Angula dirige repetidamente à vizinha após ouvir seus ensinamentos, qual seja: “- Ah! É só? Mas isso eu já sabia!”. No texto de L., o incômodo de dona Mercedes não se dá pela resposta da moça, mas pela recorrência com que ela solicitava suas receitas: "Dona Mercedes não gostou de Maria ir todo o dia la perguntar como ce faz para cozinhar, então, rezouvel dar uma lição nela” (linhas 22, 23 e 24).

O último conselho da vizinha, embora tenha sofrido algumas alterações quando da reescrita pela criança (como a substituição de "Depois espere chegar o último defunto do dia, e sem que ninguém a veja, retire as tripas e o estômago dele." por "pegue o ultimo buicho do dia”, na linha 27, e de "Ao chegar em casa, lave-os muito bem e cozinhe-os com água, sal e cebolas. Depois que ferver uns dez minutos, acrescente alguns grãos de amendoim e está pronto.” por “então va para casa e cozinhe os com cebolas e nozes!”, na linha 28), também aqui é seguido por Maria Angula. Entretanto, as partes aflitivas da narrativa, em que se descrevem as ações da personagem e o medo que ela enfrentou, inexistem na produção de L. 
Finalmente, cumpre dizer que a chegada do fantasma ao quarto de Maria Angula é pouco detalhada pela criança e que a fala do defunto violado exigindo a devolução das tripas e do estômago também é suprimida.

Por outro lado, na versão de L., a protagonista "rezou mil vezes" (linha 33) para que a assombração a deixasse e, em vez de simplesmente ser arrastada por ela e sumir, Maria Angula enfrenta as "comcecuencias" de seus atos ao tornar-se "escrava" do morto e "limpar" sua "cepultura" (linhas 35 a 37). Tais inovações em relação à obra de Uribe (1999) conferem um aspecto moral ao conto da criança, tanto pelo fator religioso acrescido por ela quanto pela definição do castigo que, no texto-fonte, não é explicitado, uma vez que a personagem apenas deixa de ser vista.

O manuscrito de L., como o de H., termina em “fim!”, mas, dessa vez, a expressão é seguida de um desenho detalhado de duas mulheres separadas por uma cerca: a primeira delas apresenta semblante bravo e a segunda parece rir enquanto diz “AH, SÓ? EU JÁ SABIA!". Assim, embora a fala marcante da protagonista, a que se deve o seu fim, esteja ausente na reescrita da criança, a ilustração que a acompanha não deixa de mencioná-la com bastante destaque.

\subsection{Resgate e aproximação em "Uma festa muito esperada"}

O quarto e último grupo de manuscritos selecionados resulta da reescrita de "Uma festa muito esperada" (TOLKIEN, 2001). Observemos o quadro 24, a seguir, em que está reproduzido o texto de $\mathrm{D}$. 
Quadro 24: Reescrita de "Uma festa muito esperada" produzida por D. e transcrita pela autora

\begin{tabular}{|c|c|}
\hline 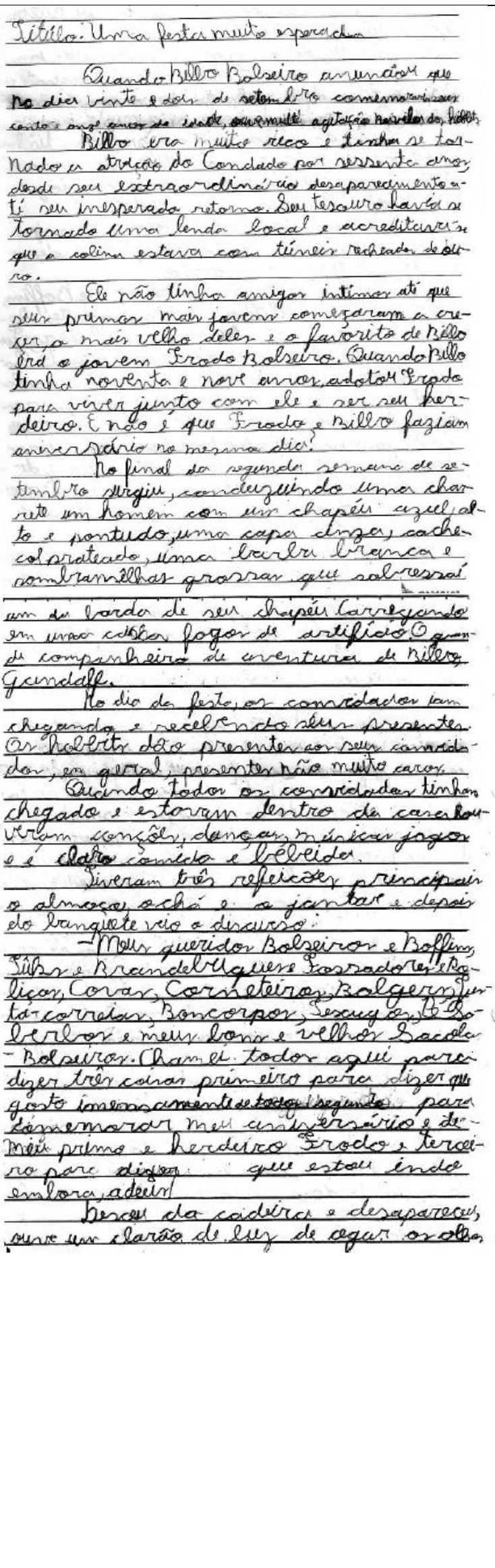 & 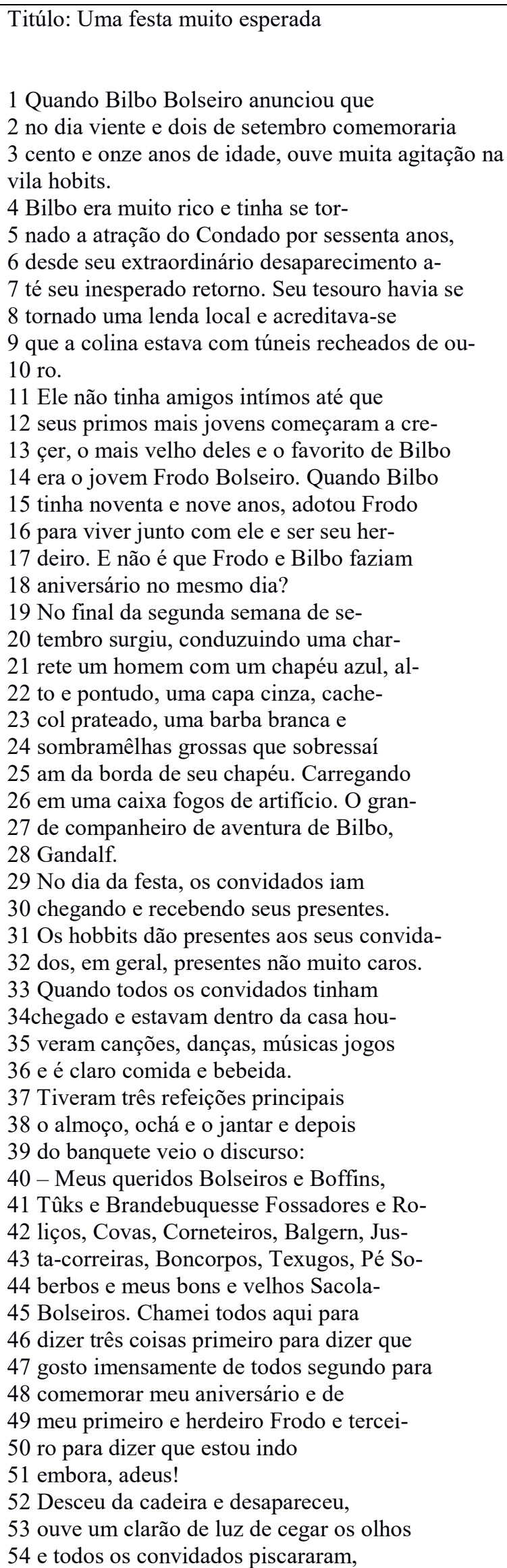 \\
\hline
\end{tabular}


\& todor on camidados piscararamy qllando abrivan or olhor, Billo não estan em lugar nenhem

lento i quarenta e queatroho bitr espantador centaram serm dizer nada e todor os comridador comefaram a discutir as enquesitisser par nedor e frisenter de Billio Bolseiro. Billo foi correndo para sua loca sem ser visto por hinguém. Evesters roupar velhor 2 dezarrumaday, opertous

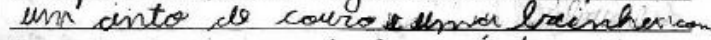
una pequena espada hor cintura, de etma gaveta trancada dheirando en safta. lina retirol uma cape e um capliz fel do sell escutorio e pegou de unia. grande calsa fortesm envelope e um liv ro escrito a mão. ha emvelope ele colocoss o anel a a slla corrento il colocour insiner La meso mex retiros -a rapidanente de lás quando a porta abries e fandape entror no excutóro. Bulloidesse Gandall que tinades férias permanenter. Contor que quesrich ver o campo selvargen es monlankas cutes de moorer \& que leveerio o anel mágico com ele.

Mor Gandalf tentor comenselo do contrario e ballo disse: - Muito lien, a anel ficará para

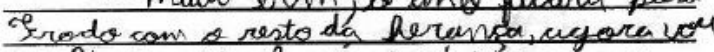
embio 2 a oll alguem veri he pegan. Depoin de Billo ir embora frcods entroes no escritór lo a encontron Gandalf pensativo. deindado a assel a fodo e froods diss $-T$ anel, ele me deixcoll ot andigor tario de salrer porgule! mar ele ainda podo ser util!

- Sonne cuido com esse and Sar do, coinar stronhor rodern acantecer com pessoas que tem esse tipo de tesorero. - hro entender- Jase trodó.

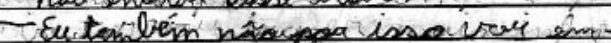
learae quainda arocimenos esserarar, en

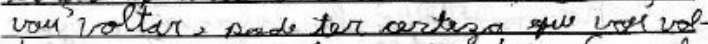
tan coen mair informacos - Diase fanded.

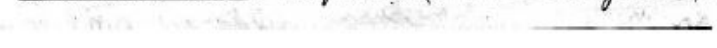

55 quando abriram os olhos, Bilbo não estava

56 em lugar nenhum.

57 Cento e quarenta e quatro hob-

58 bits espantados centaram sem dizer 59 nada e todos os convidados come-

60 çaram a discutir as esquisitisses pas61 sadas e presentes de Bilbo Bolseiro.

62 Bilbo foi correndo para sua

63 toca sem ser visto por ninguém. E vestiu 64 roupas velhas e dezarrumadas, apertou 65 um cinto de couro e uma bainha com 66 uma pequena espada $\mathrm{Na}$ cintura, de uma 67 gaveta trancada cheirando a nafta68 lina retirou uma capa e um capuz, foi 69 ao seu escritório e pegou de uma 70 grande caixa forte um envelope e 71 um livro escrito a mão.

72 No envelope ele colocou o anel

73 e a sua corrente ele colocou ensima

74 da mesa mas retirou-a rapidamente de lá, 75 quando a porta abriu e Gandalf

76 entrou no escritório.

77 Bilbo disse a Gandalf que tira-

78 ria férias permanentes. Contou que que-

79 ria ver o campo selvagem e as mon-

80 tanhas antes de morrer e que levaria

81 o anel mágico com ele.

82 Mas Gandalf tentou convenselo

83 do contario e Bilbo disse:

84 - Muito bem, o anel ficará para

85 Frodo com o resto da herança, agora vou 86 embora ou alguém vai me pegar.

87 Depois de Bilbo ir embora Frodo 88 entrou no escritório e encontrou 89 Gandalf pensativo.

90 Gandalf disse que Bilbo havia 91 deixado o anel a Frodo e Frodo disse: 92 - $\mathrm{O}$ anel, ele me deixou o anel Gos-

93 taria de saber porque! Mas ele ainda po94 de ser util!

95 - Tome cuido com esse anel Fro-

96 do, coisas estranhas podem acontecer

97 com pessoas que tem esse tipo de tesouro.

98 - Não entendo - Disse Frodo.

99 - Eu também não por isso vou em-

100 bora e quando você menos esperarar, eu 101 vou voltar e pode ter certeza que vou vol102 tar com mais informações. - Disse Gandalf.

Fonte: manuscrito de pesquisa, coletado e transcrito pela autora, 2020.

O manuscrito de D., cujo título reproduz o de Tolkien (2001), é composto por 102 linhas e guarda os elementos da narrativa original, quais sejam: Bilbo Bolseiro, herói de $O$ Hobbit (TOLKIEN, 2013) que, tendo voltado de sua jornada há sessenta anos, é reconhecido por sua riqueza e por não envelhecer, promove um evento em comemoração ao seu $111^{\circ}$ aniversário, anunciando uma grande festa ao lado de seu primo Frodo, que vive com ele e é 
escolhido como seu herdeiro; nessa ocasião, Bilbo anuncia que irá embora do Condado e, após breve discurso, coloca seu anel mágico e desaparece, causando algum alvoroço; após longa conversa com o mago Gandalf, seu companheiro de aventuras, decide deixar o anel com Frodo - que por sua vez é aconselhado a não vestir a joia -, e parte.

A produção de D. é bastante fiel ao texto-fonte, especialmente no que diz respeito ao início e ao conteúdo de seus parágrafos. Observemos o quadro 25, a seguir, com o qual é possível fazer o cotejamento entre o modo como Tolkien (2001) começa alguns de seus parágrafos e o modo como D. o faz.

Quadro 25: Cotejamento entre início de parágrafo do texto-fonte e sua reescrita

\begin{tabular}{|c|c|}
\hline Início de parágrafo do texto-fonte & $\begin{array}{l}\text { Início de parágrafo correspondente na } \\
\text { reescrita pelo aluno }\end{array}$ \\
\hline Quando Bilbo Bolseiro anunciou que & $\begin{array}{l}\text { Quando Bilbo Bolseiro anunciou que } \\
\text { (linha 1) }\end{array}$ \\
\hline Bilbo era muito rico e tinha & $\begin{array}{l}\text { Bilbo era muito rico e tinha } \\
\text { (linha 4) }\end{array}$ \\
\hline $\begin{array}{l}\text { Ele não tinha amigos íntimos, até que seus } \\
\text { primos mais jovens começaram a crescer. O } \\
\text { mais velho deles, e favorito de Bilbo, era o } \\
\text { jovem Frodo Bolseiro. Quando Bilbo tinha } \\
\text { noventa e nove anos, adotou Frodo }\end{array}$ & $\begin{array}{l}\text { Ele não tinha amigos intimos até que seus } \\
\text { primos mais jovens começaram a creçer, o } \\
\text { mais velho deles e o favorito de Bilbo era o } \\
\text { jovem Frodo Bolseiro. Quando Bilbo tinha } \\
\text { noventa e noves anos adotou Frodo } \\
\text { (linhas } 11 \text { a 15) }\end{array}$ \\
\hline No final da segunda semana de setembro & $\begin{array}{l}\text { No final da segunda semana de setembro } \\
\text { (linhas } 19 \text { e 20) }\end{array}$ \\
\hline O grande dia chegou & $\begin{array}{l}\text { No dia da festa } \\
\text { (linha 29) }\end{array}$ \\
\hline Quando todos os convidados tinham & $\begin{array}{l}\text { Quando todos os convidados tinham } \\
\text { (linha 33) }\end{array}$ \\
\hline Houve três refeições oficiais & $\begin{array}{l}\text { Tiveram três refeições principais } \\
\text { (linha 37) }\end{array}$ \\
\hline
\end{tabular}




\begin{tabular}{|c|c|}
\hline $\begin{array}{l}\text { - Meus queridos Bolseiros e Boffins, e } \\
\text { meus queridos Tûks e Brandebuques e } \\
\text { Fossadores e Roliços e Covas e Corneteiros } \\
\text { e Bolgers, Justa-correias, Boncorpos, } \\
\text { Texugos e Pé-soberbos. E também meus } \\
\text { bons Sacolas-bolseiros, }\end{array}$ & $\begin{array}{l}\text { - Meus queridos Bolseiros e Boffins, Tûks e } \\
\text { Brandebuquesse Fossadores e Roliços, } \\
\text { Covas, Corneteiros, Balgern, Justa- } \\
\text { correiras, Boncorpos, Texugos, Pé Soberbos } \\
\text { e meus bons e velhos Sacola-Bolseiros. } \\
\text { (linhas } 40 \text { a 45) }\end{array}$ \\
\hline $\begin{array}{l}\text { Desceu da cadeira e desapareceu. Houve um } \\
\text { clarão de luz de cegar os olhos e todos os } \\
\text { convidados piscaram. Quando abriram os } \\
\text { olhos, Bilbo não estava em lugar algum. }\end{array}$ & $\begin{array}{l}\text { Desceu da cadeira e desapareceu, ouve um } \\
\text { clarão de luz de cegar os olhos e todos os } \\
\text { convidados piscaram, quando abriram os } \\
\text { olhos, Bilbo não estava em lugar nenhum. } \\
\text { (linhas } 52 \text { a 56) }\end{array}$ \\
\hline $\begin{array}{l}\text { Essa informação é parte do parágrafo } \\
\text { anterior, no qual aparece redigida da } \\
\text { seguinte maneira: } \\
\text { Cento e quarenta e quatro hobbits } \\
\text { espantados se encostaram nas cadeiras sem } \\
\text { dizer nada. }\end{array}$ & $\begin{array}{l}\text { Cento e quarenta e quatro hobbits } \\
\text { espantados centaram sem dizer nada } \\
\text { (linhas } 57 \text { a 59) }\end{array}$ \\
\hline $\begin{array}{l}\text { A verdade é que quando Bilbo desceu da } \\
\text { cadeira e desapareceu, foi rapidamente de } \\
\text { volta para sua toca sem ser visto por } \\
\text { ninguém. }\end{array}$ & $\begin{array}{l}\text { Bilbo foi correndo para sua toca sem ser } \\
\text { visto por ninguém. } \\
\text { (linhas } 62 \text { e } 63 \text { ) }\end{array}$ \\
\hline $\begin{array}{l}\text { Essa informação é parte do parágrafo, mas } \\
\text { não o inicia. No meio dele, aparece } \\
\text { redigida da seguinte maneira: } \\
\text { No envelope colocou o anel de ouro, e sua } \\
\text { fina corrente, e então o selou e endereçou a } \\
\text { Frodo. }\end{array}$ & $\begin{array}{l}\text { No envelope ele colocou o anel e a sua } \\
\text { corrente } \\
\text { (linhas } 72 \text { e 73) }\end{array}$ \\
\hline $\begin{array}{l}\text { Bilbo disse a Gandalf que tiraria férias } \\
\text { permanentes }\end{array}$ & $\begin{array}{l}\text { Bilbo disse a Gandalf que tiraria férias } \\
\text { permanentes. } \\
\text { (linhas } 77 \text { e } 78 \text { ) }\end{array}$ \\
\hline $\begin{array}{l}\text { Essa informação é parte do parágrafo, mas } \\
\text { não o inicia. No meio dele, aparece } \\
\text { redigida da seguinte maneira: } \\
\text { mas Gandalf tentou convencê-lo do } \\
\text { contrário }\end{array}$ & $\begin{array}{l}\text { Mas Gandalf tentou convenselo do contrario } \\
\text { (linhas } 82 \text { e } 83 \text { ) }\end{array}$ \\
\hline
\end{tabular}




\begin{tabular}{|l|l|}
\hline $\begin{array}{l}\text { - Muito bem, o anel vai para Frodo, com } \\
\text { todo o resto da herança. E agora devo ir, ou } \\
\text { alguém vai me pegar. }\end{array}$ & $\begin{array}{l}\text { - Muito bem, o anel ficará para Frodo com } \\
\text { o resto da herança, agora vou embora ou } \\
\text { alguem vai me pegar. } \\
\text { (linhas 84 a 86) }\end{array}$ \\
\hline $\begin{array}{l}\text { Um tempo depois de Bilbo ter se despedido } \\
\text { de Gandalf e ter ido embora, Frodo entrou } \\
\text { na casa e encontrou Gandalf pensativo }\end{array}$ & $\begin{array}{l}\text { Depois de Bilbo ir embora Frodo entrou no } \\
\text { escritório e encontrou Gandalf pensativo. } \\
\text { (linhas 87 a 89) }\end{array}$ \\
\hline $\begin{array}{l}\text { O mago contou a Frodo que Bilbo havia } \\
\text { partido }\end{array}$ & $\begin{array}{l}\text { Gandalf disse que Bilbo havia deixado } \\
\text { (linhas 90 e 91) }\end{array}$ \\
\hline $\begin{array}{l}\text { - O anel! - exclamou Frodo. - Ele me } \\
\text { deixou o anel? Gostaria de saber por quê! } \\
\text { Mas ele ainda pode ser útil! }\end{array}$ & $\begin{array}{l}\text { - O anel, ele me deixou o anel? Gostaria de } \\
\text { saber porque! Mas ele ainda pode ser util! }\end{array}$ \\
(linhas 92 a 94)
\end{tabular}

Fonte: elaborado pela autora, 2020.

Conclui-se, da análise do quadro, que, além de manter os elementos gerais da obra de Tolkien (2001), o aluno respeita a ordem cronológica dos acontecimentos narrativos e retoma boa parte da paragrafação do texto-fonte como forma de organizar as partes de seu próprio texto. Dos 21 parágrafos que a produção da criança apresenta, 13 iniciam-se de forma idêntica aos parágrafos correspondentes na versão original da história. Os demais tratam dos temas abordados pelo texto-fonte, porém sua redação envolve, principalmente, alguns deslocamentos e algumas substituições e supressões vocabulares. É o caso, por exemplo, das trocas empreendidas por D. de "houve" por "tiveram" e de "oficiais" por "principais" (linha $37)$. 
No quadro 26, a seguir, observemos o manuscrito produzido por outra aluna, M., durante a reescrita de "Uma festa muito esperada" (TOLKIEN, 2001).

Quadro 26: Reescrita de "Uma festa muito esperada" produzida por M. e transcrita pela autora

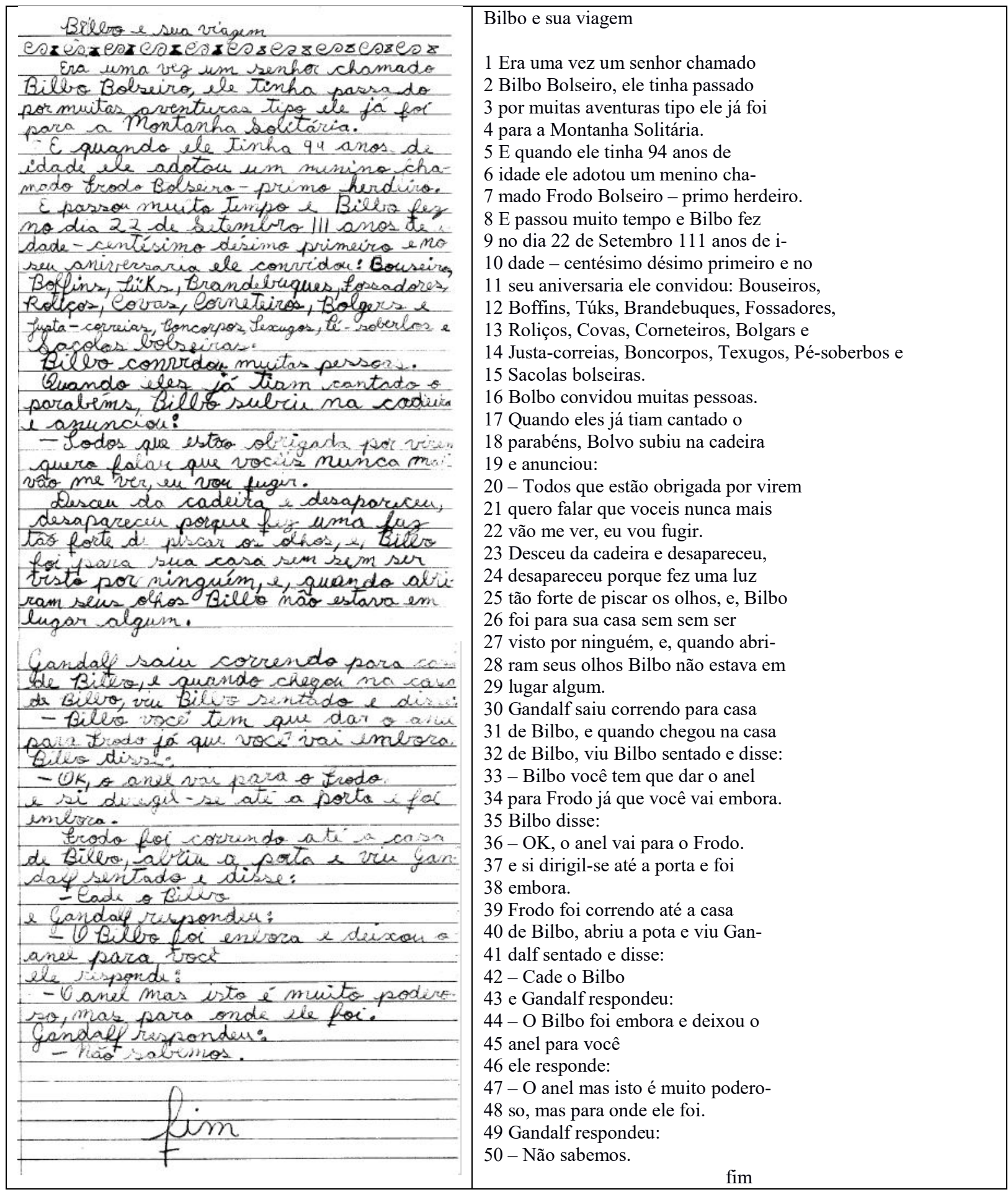

Fonte: manuscrito de pesquisa, coletado e transcrito pela autora, 2020. 
O manuscrito de M. é composto por 50 linhas. Seu título, "Bilbo e sua viagem", não reproduz o de Tolkien (2001). O texto guarda os elementos da narrativa original, quais sejam: Bilbo Bolseiro, herói de O Hobbit (TOLKIEN, 2013), promove um evento em comemoração ao seu $111^{\circ}$ aniversário, anunciando uma grande festa ao lado de seu primo Frodo, que vive com ele e é escolhido como seu herdeiro; nessa ocasião, Bilbo anuncia sua partida do Condado e, após breve discurso, coloca seu anel mágico e desaparece, causando algum alvoroço; após longa conversa com o mago Gandalf, seu companheiro de aventuras, decide deixar o anel com Frodo e parte.

Diferentemente do que ocorre no texto-fonte, a reescrita de M. inicia-se pela expressão "era uma vez", muito comum em narrativas de aventura, especialmente quando o elemento fantástico se faz presente. Além disso, antes de mencionar a festa organizada por Bilbo Bolseiro, a aluna opta por apresentar o personagem: senhor aventureiro visitante, inclusive, da "Montanha Solitária" (linha 4), que sequer foi mencionada pelo texto da atividade.

Como salientamos anteriormente, a avaliação com o texto "Uma festa muito esperada" (TOLKIEN, 2001), aplicada em novembro, foi precedida pela leitura de $O$ Hobbit (TOLKIEN, 2013), que se deu ao longo do ano letivo. Isso pode explicar o que observamos como sendo uma tendência durante as análises: as crianças acrescentam informações a respeito de Bilbo Bolseiro e seu primo, Frodo, contidas nos textos que antecedem o textofonte e também naqueles que o sucedem, uma vez que, interessados pela história dos hobbits, alguns alunos avançaram na leitura da trilogia sem serem demandados pela escola.

$\mathrm{Na}$ versão de M., somente após a referência à adoção de Frodo por Bilbo é que a festa de aniversário é anunciada, e a idade comemorada pelo personagem é apresentada em algarismos e por extenso, o que não acontece por ocasião do texto-fonte. Não há citação à chegada de Gandalf.

Os convidados, por sua vez, que na versão original são listados por Bilbo em sua fala de boas-vindas, na versão da criança são mencionados pelo próprio narrador. Impressiona, como no caso de D., que M. lembre-se de todas as famílias de seres convidados e, ainda, da ordem em que são apresentados por Tolkien (2001).

Ademais, "o parabéns" (linha 18) que ocorre na história da criança e que aproxima o evento narrativo do universo das festas infantis inexiste no texto-fonte. Outra diferença para a versão inglesa está na fala de Bilbo, que anuncia sua partida dizendo que vai "fugir" (linha 22). 
Embora menos detalhado, o diálogo que, a seguir, se estabelece entre Bilbo e o mago tem função semelhante ao retratado pelo texto-fonte. Um último acréscimo feito pela criança é da expressão "fim”" para o encerramento de sua produção.

No quadro 27, a seguir, consta o manuscrito de O., produzido durante a reescrita do mesmo texto-fonte.

Quadro 27: Reescrita de "Uma festa muito esperada" produzida por O. e transcrita pela autora

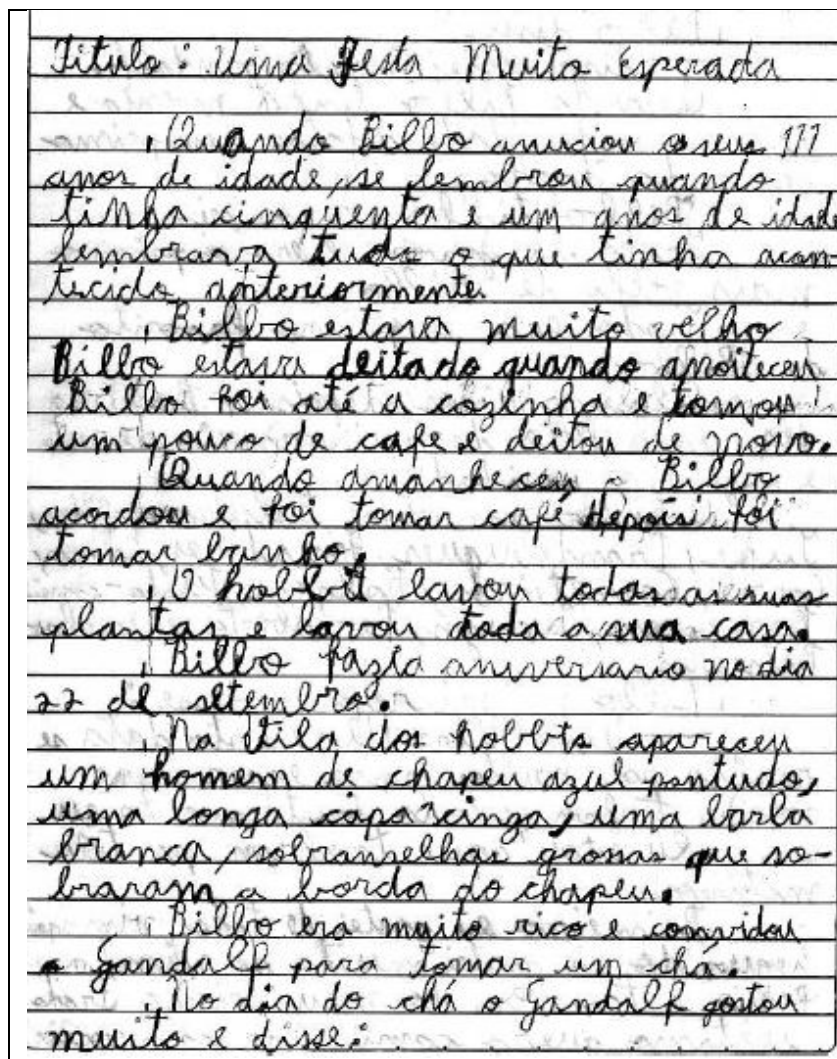

Título: Uma Festa Muito Esperada

1 Quando Bilbo anusciou o seus 111

2 anos de idade, se lembrou quando

3 tinha cincquenta e um anos de idade

4 lembrava tudo o que tinha acon-

5 tecido anteriormente

6 Bilbo estava muito velho

7 Bilvo estava deitado quando anoiteceu

8 Bilbo foi até a cozinha e tomou

9 um pouco de cafe e deitou de novo.

10 Quando amanheceu o Bilbo

11 acordou e foi tomar café depois foi

12 tomar banho.

$13 \mathrm{O}$ hobbit lavou todas as suas

14 plantas e lavou toda a sua casa.

15 Bilbo fazia aniversario no dia

1622 de setembro.

$17 \mathrm{Na}$ Vila dos hobbts apareseu

18 um homem de chapeu azul pontudo,

19 uma longa capa cinza, uma barba

20 branca, sobranselhas grossas que so-

21 braram a borda do chapeu.

22 Bilbo era muito rico e convidou

23 o Gandalf para tomar um chá.

24 No dia do chá o Gandalf gostou

25 muito e disse:

26 - Bolseiro gostei muito do cha

27 espero que tenha gostado.

28 Bilbo disse

29 - Sim gostei muito Gandalf.

30 Quando Bilbo tinha noventa e

31 nove anos de idade adotou seu primo

32 chamado Frodo.

33 Bilbo tinha varios primos.

34 Frodo era jovem e era o primo

35 mais velho de Bilbo.

36 Frodo era o primo favorito

37 de Bilbo.

38 Alguns anos depois o Bolseiro

39 fez uma festa de aniversario de cento

40 e onze anos de idade.

41 O Bilbo convidou Bolseiros, Boffins,

42 Tuks, Brandebuques, Fossadores, Roliços,

43 Covas, Corneteiros, Bolgers, Justa-correias,

44 Bomcorpos, Texugos, Pe-sobertas e Sacolas-

45 Bolseiros. 


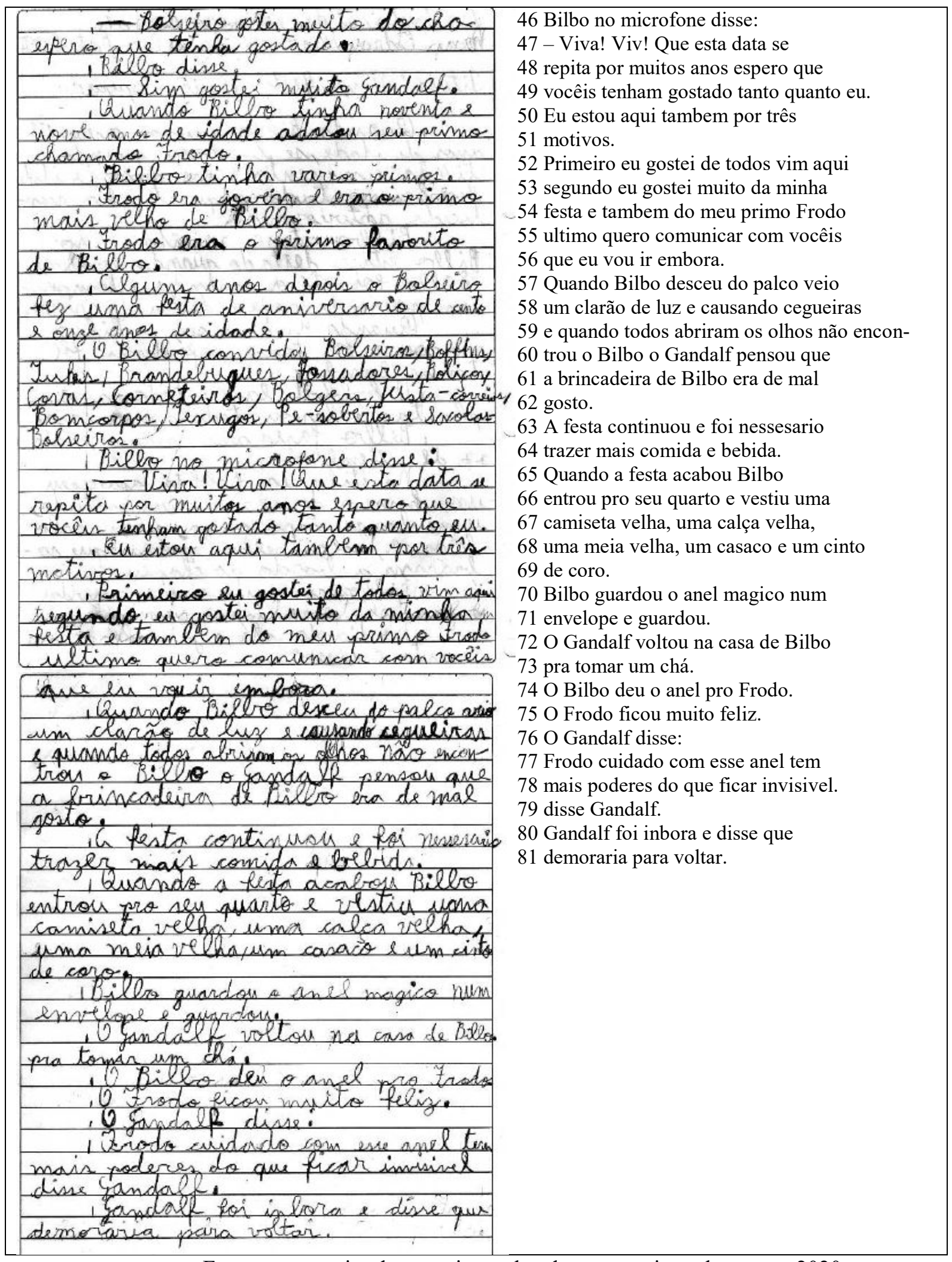

Fonte: manuscrito de pesquisa, coletado e transcrito pela autora, 2020.

O manuscrito de O. é composto por 81 linhas. Seu título reproduz o de Tolkien (2001). Em linhas gerais, o texto guarda os elementos da narrativa original, quais sejam: Bilbo 
Bolseiro, herói de O Hobbit (TOLKIEN, 2013), promove um evento em comemoração ao seu $111^{\circ}$ aniversário, anunciando uma grande festa ao lado de seu primo Frodo, que vive com ele e é escolhido como seu herdeiro; nessa ocasião, Bilbo anuncia sua partida do Condado e, após breve discurso, coloca seu anel mágico e desaparece, causando algum alvoroço; após conversa com o mago Gandalf, seu companheiro de aventuras, decide deixar o anel com Frodo. Nesse caso, porém, Bilbo não parte ao final da narrativa, apenas Gandalf.

Embora a primeira linha da versão do aluno pareça indicar uma reescrita próxima ao texto-fonte, o que se segue são acréscimos empreendidos por ele. Nesse sentido, os quatro parágrafos iniciais (linhas 2 a 14) de sua produção estão recheados de informações e acontecimentos inexistentes na versão original, quais sejam: Bilbo, apesar de "muito velho", recorda-se com clareza de quando tinha 51 anos (idade que, no texto-fonte, só será mencionada quando Bilbo contar, durante seu discurso de anfitrião, que nessa época chegou de barril à Cidade do Lago); certa noite, o hobbit decide levantar-se para ir até a cozinha tomar café e, em seguida, deita-se novamente; ao amanhecer, ele toma café e encaminha-se para o banho; em seguida, lava suas plantas e sua casa.

Acreditamos que, por já conhecerem a história desse personagem, graças às leituras que fizeram ao longo do ano, os alunos tendem a incrementar a narrativa a seu respeito. Muitas vezes, acrescentam dados contidos nos textos trabalhados anteriormente, mas não raro dão a ver tentativas de aproximar a narrativa do personagem, por quem já parecem nutrir algum afeto ou com quem estabeleceram certa intimidade, de sua realidade. É o caso, por exemplo, de dizer que Bilbo, antes de promover "uma festa de especial grandeza" (TOLKIEN, 2001), realizou tarefas cotidianas como regar as plantas e arrumar a casa.

Ao mencionar a data de aniversário de Bilbo e descrever a aparição de Gandalf de modo muito semelhante ao que faz Tolkien (2001), O. parece retomar o conteúdo do textofonte, no entanto, logo volta a operar transformações em relação a ele: o mago não chega apenas para a festa do hobbit; é, antes, convidado para um chá em sua casa, do qual afirma ter gostado muito (linhas 26 e 27).

Finalmente, O. menciona os vários primos de Bilbo e a adoção de Frodo, e só então passa a falar da comemoração pelos 111 anos do hobbit. Descreve, com extrema fidelidade ao texto-fonte, as famílias presentes no evento, mas atribui ao anfitrião a fala que, na versão original, seria dos convidados: “- Viva! Viva! Que esta data se repita por muitos anos” (linhas 47 e 48$)$. 
$\mathrm{Na}$ produção da criança, após ouvir o anúncio de partida e presenciar o sumiço, Gandalf (e não os demais convidados, como consta no texto-fonte) considera como sendo de mau gosto a brincadeira de Bilbo. Somente após o encerramento da festa, o hobbit se prepara para a partida e embrulha o anel em um envelope. Na narrativa de O., Gandalf vai ao seu encontro para tomar um chá, o que parece não acontecer, pois sem muitos detalhes o leitor vem a saber que Bilbo decide deixar o anel para Frodo, que, por sua vez, fica feliz, mas nada diz. Sequer sabemos se a joia foi entregue em mãos.

A fala do mago, que aconselha Frodo a tomar cuidado com o anel, e sua partida são mantidas pelo aluno. Contudo, não se sabe se Bilbo chega, de fato, a ir embora.

\subsection{Uma primeira síntese}

Neste capítulo, interessadas na possibilidade de que as especificidades de dados textos-fonte impactassem os efeitos de sentido gerados durante a reescrita por parte das crianças, selecionamos, para cada uma das quatro atividades avaliativas,três manuscritos completos, a fim de ilustrar algumas tendências que se foram observando durante a análise do corpus.

Por ocasião da reescrita de "A rainha da bateria (VILA, 2009), observamos uma predisposição a que as crianças exponham o que, em sua visão, uma senhora preconceituosa poderia dizer a respeito dos frequentadores de um espaço que ela não deseja que sua filha visite. Ao que parece, para alguns alunos, morar no morro não é motivo de desqualificação, ao contrário de ser "chata, rica, mimada" e não gostar dos filhos.

Ademais, acreditamos na possibilidade de que o repertório de algumas crianças tenha dificultado a compreensão típica desse texto, em que o autor faz uso de termos talvez incomuns ao universo das crianças participantes e há muitas referências, às vezes bastante específicas, ao universo carnavalesco. Por isso, "compositor de uma grande escola de samba" dá lugar a "chefe de uma escola de samba", "iPod" dá lugar a "chip", "Diretor de Bateria" dá lugar a "rei da bateria" e tantas outras substituições vocabulares são feitas, além dos variados gêneros e instrumentos musicais que, na maior parte das vezes, sequer são listados pelos participantes.

A atividade com a lenda "João-de-barro" (SÓHISTÓRIA, 2019), por sua vez, foi aquela que rendeu maior número de reescritas próximas ao texto-fonte, como poderíamos prever pela análise das frases de abertura empreendida no capítulo 3 desta dissertação. 
Possivelmente, isso se deva à extensão do texto-fonte, menor em relação aos demais, e à simplicidade do seu vocabulário se comparado, por exemplo, ao texto "A rainha da bateria" (VILA, 2009).

Já na atividade que envolveu o texto "Maria Angula (Equador)" (URIBE, 1999), chamam a atenção os casos em que não se faz menção ao Equador no título das produções. Trata-se do país de origem da história, mas que nem por isso é citado no texto-fonte, durante a execução da atividade pela professora ou nos exercícios de interpretação textual anteriores à produção escrita pelos alunos.

Ainda durante a reescrita desse texto-fonte pelas crianças, houve uma tendência à supressão das partes mais aflitivas, como aquelas em que Maria Angula viola o morto e, mais tarde, é assombrada pelo fantasma do mesmo, e à inserção de um aspecto moralizante ao castigo sofrido pela protagonista por seguir o conselho da vizinha. Dona Mercedes, que é quem sugere a violação do morto por vingança, não é punida. Maria Angula, contudo, que é descrita como fofoqueira e durante a narrativa adota uma postura ingrata, prepotente e mentirosa, tem as consequências de seus atos detalhadas por muitas das crianças, embora no texto-fonte a personagem apenas suma.

Enfim, nos textos resultantes da reescrita de "Uma festa muito esperada" (TOLKIEN, 2001), observamos uma inclinação à inserção de informações a respeito de Bilbo e suas aventuras que constam, principalmente, em textos lidos ao longo do ano e que, na produção de Tolkien, antecedem a obra trabalhada durante a atividade avaliativa.

Finalmente, cumpre dizer das tendências observadas durante a reescrita de dois ou mais textos-fonte.

Tanto no caso da reescrita do texto "João-de-barro" (SÓHISTÓRIA, 2019), quanto no caso da reescrita de "A rainha da bateria" (VILA, 2009), houve uma tendência à supressão, por parte dos alunos, dos parágrafos finais das narrativas, em que juízos de valor sobre seus elementos centrais (escolas de samba, amor incondicional) são apresentados. É como se a fala do narrador que encerra o texto tivesse um apelo inferior à sucessão dos fatos ocorridos com seus personagens, aos quais os alunos se vinculam e cujas histórias eles se dispõem a contar.

Quanto às reescritas de "João-de-barro" (SÓHISTÓRIA, 2019) e "Maria Angula (Equador)" (URIBE, 1999), observa-se uma inclinação, por parte das crianças, à demonstração de afeto ou falta dele pelos personagens da narrativa. Nesse sentido, a Jaebé são atribuídas características positivas ("inteligenti legal e bonito", "moço forte”, “corajoso"), enquanto ao seu sogro e à Maria Angula são atribuídos traços negativos ("bravo homem" e 
"não era uma boa pessoa"; "que maltratava os animais", "que vivia metendo as pessoas em frias", entre outros).

Além disso, embora em todas as atividades tenham sido muito comuns casos de atualização da narrativa para uma outra realidade, durante as reescritas de abril e agosto esse movimento deu-se especialmente em relação ao casamento dos personagens. Assim, em "João-de-barro", um participante opta por criar um Jaebé que não pede ao futuro sogro a mão da amada em casamento, mas fala diretamente com ela, enquanto em "Maria Angula (Equador)" a protagonista se casa mais velha do que na versão original, em que o faz aos 16 anos.

Por fim, em “João-de-barro" (SÓHISTÓRIA, 2019) e "Uma festa muito esperada" (TOLKIEN, 2001), observamos a intensa inserção de diálogos que não existem nas versões originais de texto. Acreditamos que a escrita em discurso direto aproxime a produção das crianças de suas experiências cotidianas de fala.

Resta dizer que, nas quatro ocasiões, dezenas de expressões como "era uma vez" e "fim" foram incluídas, respectivamente, no início e no fim das narrativas pelos participantes.

Por fim, para sintetizar, podemos afirmar que a presença dos seguintes elementos na obra original parece ter facilitado o advento de textos que não se limitaram a reproduzir os textos-fonte:

1) Afirmações de caráter ideológico que, ao provocar discordância por parte das crianças, deram origem a produções dissonantes;

2) Termos e referências incomuns ao universo das crianças participantes, que deram origem a substituições e supressões;

3) Partes aflitivas que tendem a ser suprimidas; e

4) Descrição das qualidades positivas ou negativas dos protagonistas, aos quais as crianças tendem a destinar castigos ou recompensas.

Todos eles apontam para uma autoria em advento, resultante, por sua vez, de um rearranjo que as crianças operam entre as palavras e vozes características dos discursos com os quais convivem e a sua própria palavra, através da qual dizem também a que vêm. Dito de outro modo, levanto em conta o conjunto de valores estabelecidos pelas interações sociais, esses alunos chegam a desviar-se das formas padronizadas de expressão, revelando sinais - ou indícios - de autoria decorrentes da associação entre o surgimento de um estilo próprio e um posicionamento enunciativo, mesmo que isso apresente riscos. 


\section{Considerações finais}

Ao longo deste trabalho, no qual visamos a investigar o que ocorre quando crianças do último ano do ciclo de alfabetização são solicitadas a reescrever textos-fonte, sem consulta, o mais próximo possível do original, tomamos as produções de alunos do terceiro ano do Ensino Fundamental I para discutir se, dado o contexto em que foram solicitadas, o de um pedido de redações na acepção de Geraldi (1985), haveria margem para as crianças introduzirem algo de si em um espaço além do "não-vida" (p. 121).

Ao minuciarmos as operações sistemáticas da escritura (GRÉSILLON; LABRAVE, 1983; GRÉSILLON, 2007) utilizadas para reescrever a frase de abertura dos textos-fonte, descobrimos que houve prevalência das supressões e substituições, seguidas pelos acréscimos. A ocorrência de deslocamentos foi pequena, superando apenas o número de reproduções fiéis.

No entanto, o modo como cada criança atendeu às instruções oferecidas, trabalhou o texto-fonte e promoveu tais alterações foi bastante único. Ao analisar as produções dos participantes, pudemos observar marcas linguísticas que singularizam os escreventes ao operarem expedientes argumentativos a serviço, por exemplo, de sensibilizar o que poderia ser um leitor do texto.

Por isso, é hora de retomarmos o título de nosso trabalho: “A rebelião dos pequenos copistas: marcas de reescrita em textos produzidos por crianças". Neste momento, imaginamos que, dadas as análises empreendidas nos capítulos precedentes, o subtítulo já estará claro para o leitor. Entretanto, julgamos ainda necessário fazer um retorno à metáfora que consta na primeira parte do nome. É lícito nomear os alunos como "rebeldes"? E, se for o caso, contra o que eles se rebelam?

Mais do que contra um comando ou um texto-fonte, pareceu-nos que os alunos se rebelam contra uma expectativa, qual seja, a de que se comportem como copistas e dêem a ver, como frutos de sua reescrita, cópias perfeitas do texto previamente ofertado. A rebelião à qual nos referimos, contudo, não configura uma oposição ativa, mas ocorre pelo deslizamento da linguagem.

Tendo isso em vista, buscamos discutir a perspectiva do método de ensino único. Para que uma só metodologia desse conta de tais singularidades, a linguagem precisaria ser encarada como meio ou código, e não como campo polissêmico e plurívoco, e a leitura precisaria ser entendida como decodificação de símbolos linguísticos, concepções que esta dissertação visou a debater. 
Por sua vez, ao analisar as especificidades dos textos gerados por diferentes textosfonte, percebemos que aspectos das versões originais das narrativas impactam os efeitos de sentido construídos durante a reescrita por parte das crianças. Algumas das tendências observadas foram as substituições decorrentes dos desafios de repertório em "A rainha da bateria" (VILA, 2009), a proximidade com o texto-fonte em “João-de-barro" (SÓHISTÓRIA, 2019), a supressão de partes aflitivas em "Maria Angula (Equador)" (URIBE, 1999) e a inserção de informações a respeito dos personagens em "Uma festa muito esperada" (TOLKIEN, 2001).

Finalmente, ao examinar a presença de autoria em textos que são fruto da reescrita de textos-fonte, notamos que a relação estabelecida pelos alunos com as obras e com a demanda escolar nos remete ao que afirma Possenti (2002b, p. 65) quando da constituição do eu pelo outro: "a presença do outro não é suficiente para apagar a do eu, é apenas suficiente para mostrar que o eu não está só”.

Dos textos analisados, emergem vozes com as quais os escreventes dialogam, como a de sua professora, que é também avaliadora, do texto-fonte e da instituição escolar. Mas é também observável, como se pôde argumentar ao longo deste trabalho, que o sujeito participante da atividade inscreve-se nas produções, e o faz considerando os limites impostos pela alteridade constitutiva.

Assim, o conjunto da pesquisa indica que, mesmo em tarefas de caráter predominantemente parafrástico, os participantes acabam gerando, de maneira mais ou menos voluntária, efeitos de sentido que, junto ao leitor, se configuram como autorais.

Contudo, mesmo nos trechos em que tais efeitos de sentido são mais facilmente visíveis, as crianças trabalham sobre o discurso do outro. Em outras palavras, não se pode conceber que seus enunciados tenham origem no próprio participante que, ora retomando o texto-fonte, ora rompendo com ele, posiciona-se subjetivamente, encarando-o justamente como ponto de partida para a criação de um texto que diga algo de si ou, mais adiante, que contribua com a cultura de maneira única.

Logo, não se trata de pensar um sujeito independente, mas aquele que "joga" com o discurso do outro de maneira singular - expondo-se e retirando-se de cena sutilmente, isto é, revelando indícios de autoria -, ainda que submetido a regras e valores estabelecidos por outrem (a professora, o comando de prova), arriscando-se e, por isso mesmo, dando a ver marcas de um estilo próprio. 
Para concluir, resta dizer que nossos achados têm aberto um campo pouco explorado de pesquisas a respeito da conquista da autoria por parte de alunos do Ensino Fundamental I. Classicamente, a presença de rasuras em textos redigidos por crianças um pouco mais velhas do que as participantes deste estudo tem sido associada à construção de autoria (FIAD, 2009). Como, a exemplo de Bezerra (2013), localizamos a presença maciça da substituição durante a reescrita por crianças de 8 anos, um estudo mais específico a respeito das substituições realizadas poderia fornecer importantes subsídios para os pesquisadores em aquisição da escrita.

Finalmente, a presente reflexão visou a diminuir uma relativa ausência de estudos a respeito de paráfrase em contexto escolar, especialmente nos primeiros anos do Ensino Fundamental, e de trabalhos que se voltam à descrição detalhada dos mecanismos linguísticodiscursivos utilizados por crianças ao reescreverem textos-fonte. Acreditamos que o estudo dos modos como alunos reformulam o que lêem e ouvem no início da escolarização pode oferecer pistas para aqueles interessados em temas que envolvam a possibilidade de educar crianças para conquistar a autoria. 


\section{Referências bibliográficas}

ALVAREZ, B. L. P. As luzes do cronotopo da avaliação: dissertações de vestibular e retração da autoria. 144f. Dissertação (Mestrado em linguística aplicada) - Universidade de São Paulo, Faculdade de Filosofia, Letras e Ciências Humanas, Departamento de Letras Clássicas e Vernáculas, 2018.

BAKHTIN, M. Os gêneros do discurso. Estética da criação verbal. São Paulo: Martins Fontes, 2003.

BATISTA, Y. A.; TORGA, V. L. M. Paráfrase discursiva e o jogo alusivo na escrita (auto) biográfica de Bartolomeu Campos de Queirós. Miguilim - Revista Eletrônica do Netlli, v. 7, n. $2,2018$.

BELINTANE, C. O desafio de ensinar a leitura e a escrita no contexto do ensino fundamental de nove anos. Projeto de pesquisa. São Paulo: Universidade de São Paulo, 2010 .

BENVENISTE, E. Problemas de Linguística Geral I. 3. ed. São Paulo: Pontes, 1991.

BEZERRA, L. M. D. O uso de operações linguístico-discursivas da crítica genética na reescritura de textos. 198f. Tese (Doutorado em estudos da linguagem) - Universidade Federal do Rio Grande do Norte, Centro de Ciências Humanas, Letras e Artes, Departamento de Letras, 2013. Disponível em: https://repositorio.ufrn.br/jspui/handle/123456789/16378. Acesso em: 09 jun. 2019.

BIASOTTO, M.; CONCEIÇÃO, R. I. S. O processo de reescrita mediado pela correção: mecanismos de parafrasagem. Raído, Dourados, v. 9, n. 18, p. 35-57, jul. 2015. Disponível em: http://ojs.ufgd.edu.br/index.php/Raido/article/view/3898. Acesso em: 24 mar. 2020.

BRÄKLING, K. L. Orientações didáticas fundamentais sobre as expectativas de aprendizagem de língua portuguesa. Anos Iniciais do Ensino Fundamental ( $1^{\circ}$ ao $5^{\circ}$ ano). São Paulo: Secretaria da Educação, 2013. Disponível em: http://www.educacao.sp.gov.br/a2sitebox/arquivos/documentos/963.pdf. Acesso em: 27 mar. 2019. 
BRASIL. Base Nacional Comum Curricular: Educação Infantil e Ensino Fundamental. Brasília: MEC/Secretaria de Educação Básica, 2017.

CALIL, E. Autoria: a criança e a escrita de histórias inventadas. Maceió: Edufal, 1998.

CALIL, E. Escutar o invisível: escritura \& poesia na sala de aula. São Paulo: Editora UNESP; Rio de Janeiro: FUNARTE, 2008.

CALIL, E. Família atrapalhada: uma análise do processo de rasuramento em texto escrito por crianças. Manuscrítica. Revista de Crítica Genética, São Paulo, n. 6, p. 93-111, 1996. Disponível em: http://revistas.fflch.usp.br/manuscritica/article/view/873. Acesso em: 09 jun. 2019.

CALIL, E.; LIMA, M. H. A. Nomes próprios em histórias inventadas: odores de um encadeamento. In: CALIL, E. (Org.). Trilhas da autoria: leitura, autoria e ensino. São Paulo: Cortez, 2007. p. 111-131.

CAMPOS, C. S. D. C. A qualidade das narrativas infantis escritas: inferências e tergiversações. In: ENCONTRO DO CELSUL, 8., 2008, Porto Alegre. Anais... Porto Alegre: UFRGS, 2008. Disponível em: http://www.leffa.pro.br/tela4/Textos/Textos/Anais/CELSUL_VIII/ling\%20textualClaudia\%20Susana\%20Dias\%20Crespi\%20de\%20Campos.pdf. Acesso em: 13 abr. 2019.

CAMPOS, S. F. A paráfrase como ponto de estagnação na escrita acadêmica. Revista do GELNE, v. 16, n. 1/2, p. 149-166, mar. 2017.

COSTA, R. O. A(r)riscar-se: o estilo na escrita de crianças. 2019. 190f. Tese (Doutorado em Educação) - Faculdade de Educação, Universidade de São Paulo, São Paulo, 2019.

COSTA, R. O. Indícios de estilosidade: estilo e autoria em textos de crianças do ensino fundamental. In: GONÇALVES-SEGUNDO, P. R. et al. (Orgs.). Discurso e Linguística: diálogos possíveis. São Paulo: Editora Paulistana, 2016. p. 266-280.

D'ALESSANDRO, S. L. Entre repetir e interpretar: um estudo da reescrita por crianças. Tópicos Educacionais, $\quad$ v. 24, n. 2, dez. 2019. Disponível em: https://periodicos.ufpe.br/revistas/topicoseducacionais/article/view/242907. Acesso em: 22 set. 2020 . 
DE BORBA, P. J.; BARRETO, S. R.; FLÔRES, O. C. Conto e reconto: a paráfrase em sala de aula. Revista Jovens Pesquisadores, Santa Cruz do Sul, v. 5, n. 1, maio 2015. Disponível em: https://online.unisc.br/seer/index.php/jovenspesquisadores/article/view/5873. Acesso em: 24 mar. 2020.

ESCOLA DE APLICAÇÃO. Regimento escolar. São Paulo, 2017. Disponível em: http://www3.ea.fe.usp.br/normas-regras-procedimentos/regimento-escolar/. Acesso em: 15 set. 2020 .

FAIRCHILD, T. M. Conhecimento técnico e atitude no ensino de língua portuguesa. Educação e Pesquisa, São Paulo, v. 35, n.3, p. 495-507, set./dez. 2009.

FIAD, R. S. Episódios de reescrita em textos infantis. Estudos linguísticos, São Paulo, 38, p. 9-18, maio/ago. 2009. Disponível em: http://www.gel.org.br/estudoslinguisticos/volumes/38/EL_V38N2 01.pdf. Acesso em: 13 abr. 2019.

FLÔRES, O. C. Quando as crianças passam a entender que dois textos querem dizer o mesmo, ainda que as palavras neles contidas sejam diferentes? Revista da Anpoll, Florianópolis, v. 1, n. 37, p. 134-144, jul./dez. 2014. Disponível em: https://revistadaanpoll.emnuvens.com.br/revista/article/view/776. Acesso em: 13 abr.2019.

FOUCAULT, M. O que é um autor? In: FOUCAULT, M. Ditos e escritos III: Estética literatura e pintura, música e cinema. Tradução de Inês Barbosa. Rio de Janeiro: Forense Universitária, 2001. p. 264-298.

FRANCHI, C. Linguagem - Atividade constitutiva. Cad. Est. Ling., Campinas, v. 22, p. 939, jan./jun. 1992.

FUCHS, C. A paráfrase linguística - equivalência, sinonímia ou reformulação. Tradução de João Wanderley Geraldi. Cadernos de estudos linguísticos, Campinas, v. 8, n. 8, p. 129-134, 1985.

FUCHS, C. Paraphrase et énonciation. Paris: Ophrys, 1994.

GERALDI, J. W. (Org.). O texto na sala de aula. Cascavel: Assoeste, 1985.

GERALDI, J. W. Portos de passagem. São Paulo: Martins Fontes, 1997. 
GIL, B. D. Quem mandou você gostar?; um estudo léxico-semântico do amor-paixão em letras de música preferenciais de alunos do ensino médio. 2002. 275f. Tese (Doutorado em Linguística) - Faculdade de Filosofia, Letras e Ciências Humanas, Universidade de São Paulo, São Paulo, 2002.

GINZBURG, C. Sinais: raízes de um paradigma indiciário. In: GINZBURG, C. Mitos, emblemas, sinais: morfologia e história. São Paulo: Companhia das Letras, 1986. p. 143179.

GONZALES, K. L. O. Um estudo sobre a paráfrase em redações de vestibular. 2014. 117f. Dissertação (Mestrado em Filologia) - Faculdade de Filosofia, Letras e Ciências Humanas, Universidade de São Paulo, São Paulo, 2014.

GRÉSILLON, A.; LABRAVE, J. Avant-propos. In: GRÉSILLON, A.; LABRAVE, J. Langages.Paris: Larousse, 1983. p. 62-69.

GRÉSILLON, A. Elementos de crítica genética: como ler os manuscritos modernos. Tradução de Cristina de Campos Velho Birck. Porto Alegre: Editora da UFRGS, 2007.

GUIMARÃES, D. C. A produção de paráfrases para a ampliação vocabular. 2015. 165f. Dissertação (Mestrado em Letras) - Universidade Federal de Uberlândia, Uberlândia, 2015.

GUSSO, A. M.; DALLA-BONA, E. M. A reescrita do texto literário de alunos dos anos iniciais da escolarização. Educar em Revista, Curitiba, n. 52, p. 69-84, abr./jun. 2014. Editora UFPR. Disponível em: http://www.scielo.br/pdf/er/n52/05.pdf. Acesso em: 13 abr. 2019.

HILGERT, J. G. Parafraseamento. In: JUBRAN, C. C. A. S.; KOCH, I. G. V. (Orgs.). Gramática do português culto falado no Brasil. Campinas: Editora da UNICAMP, 2006.

KIDA, A. S. B. et al. Influência da modalidade de reconto na avaliação do desempenho de escolares em compreensão leitora. Estudos de psicologia., Campinas, v. 32, n. 4, p. 605-615, dez. 2015. Disponível em: http://www.scielo.br/pdf/estpsi/v32n4/0103-166X-estpsi-32-0400605.pdf. Acesso em: 15 abr. 2017.

LAJOLO, M. O texto não é pretexto. In: ZIBERMAN, R. (Org.). Leitura em crise na escola: as alternativas do professor. Porto Alegre: Mercado Aberto, 1982. p. 51-62. 
LAJONQUIÈRE, L. A infância que inventamos e as escolas de ontem e de hoje. Estilos da clínica, São Paulo, v. 8, n. 15, jun. 2003.

LAJONQUIÈRE, L. A palavra e as condições da educação escolar. Educação \& Realidade, Porto Alegre, v. 38, n. 2, p. 455-469, abr./jun. 2013.

LAJONQUIÈRE, L. De Piaget a Freud: para repensar as aprendizagens. A (psico)pedagogia entre o conhecimento e o saber. Petrópolis: Vozes, 1992.

LAJONQUIÈRE, L. Infância e ilusão (psico)pedagógica: escritos de psicanálise e educação. São Paulo: Vozes, 1999.

LESLIE, L.; CALDWELL, J. Formal and informal measures of reading comprehension. In: ISRAEL, S. E.; DUFFY, G. G. Handbook of research on reading comprehension. New York: Taylor \& Francis, 2009. p. 403-27.

MACHADO, A. R. “O plantador de naus a haver" sob a óptica da intertextualidade. 2006. 117f. Dissertação (Mestrado em Literatura Portuguesa) - Faculdade de Filosofia, Letras e Ciências Humanas, Universidade de São Paulo, São Paulo, 2006.

MAGALHÃES, M. M. M. Subjetividade em advir: a construção da metáfora em textos de alunos da escola básica. 2007. Dissertação (Mestrado em Educação) - Faculdade de Educação, Universidade de São Paulo, São Paulo, 2007.

MARCUSCHI, L. A. Produção textual, análise de gênero e compreensão. São Paulo: Parábola Editorial, 2008.

MARINHEIRO, T. S.; BORGES, F. C. V. Paráfrase e polissemia: produções textuais escritas na escola. Nucleus, Ituverava, v. 8, n. 1, p. 133-150, abr. 2011. Disponível em: http://www.nucleus.feituverava.com.br/index.php/nucleus/article/view/549. Acesso em: 13 abr. 2019.

MENEGASSI, R. J.; EMILIANO, S. R. A paráfrase criativa como característica do leitor competente em textos de vestibular. Acta Scientiarum. Human and Social Sciences, v. 26, n. 2, p. 209-219, 2008. 
MORAES, E. A. N. A importância dos modelos nas atividades de escrita e a liberdade de criação. 2009. 182f. Dissertação (Mestrado em Educação) - Faculdade de Educação, Universidade de São Paulo, São Paulo, 2009.

NASCIMENTO, C. A. Uma leitura intertextual da história e da literatura portuguesas por Helder Costa. 2015. 151f. Dissertação (Mestrado em Literatura Portuguesa) - Faculdade de Filosofia, Letras e Ciências Humanas, Universidade de São Paulo, São Paulo, 2015.

NEGREIROS, G. A presença da oralidade na poesia de Carlos Drummond de Andrade: repetições e paráfrases no texto poético. Linha D’Água, n. 22, p. 119-127, 2009.

NÓBREGA, M. J. M. Paráfrase, autoria e processos de assimilação da palavra do outro. 2000. 173f. Dissertação (Mestrado em Filologia e Língua Portuguesa) - Faculdade de Filosofia, Letras e Ciências Humanas, Universidade de São Paulo, São Paulo, 2000.

NÓBREGA, M. J. M. Redigindo textos, assimilando a palavra do outro. Revista Veras, São Paulo, v. 1, n. 1, p. 22-34, 2011. Disponível em: http://site.veracruz.edu.br/instituto/revistaveras/index.php/revistaveras/article/view/3. Acesso em: 13 abr. 2019.

ORLANDI, E. P. (1942) Interpretação: autoria, leitura e efeitos do trabalho simbólico. Petrópolis: Vozes, 1996.

PACÍFICO, S. M. R. Argumentação e autoria: o silenciamento do dizer. 2002. 190f. Tese (Doutorado em Psicologia) - Faculdade de Filosofia, Ciências e Letras de Ribeirão Preto, Universidade de São Paulo, Ribeirão Preto, 2002.

PATTO, M. H. S. A produção do fracasso escolar: histórias de submissão e rebeldia. São Paulo: Intermeios, 2015.

PÊCHEUX, M. Análise automática do discurso (AAD-69). In: GADET, F.; HAK, T. Por uma análise automática do discurso: uma introdução à obra de M. Pêcheux. Campinas: Editora da Unicamp, 1997. p. 61-105.

PÊCHEUX, M. Papel da memória. In: ACHARD, P. et al. (Org.). Papel da memória. Campinas/São Paulo: Pontes, 1999. p. 49-57. 
PERRONE, C. A. Do mito à fábula: releituras de Lobato. 2002. 197f. Dissertação (Mestrado em Letras) - Faculdade de Filosofia, Letras e Ciências Humanas, Universidade de São Paulo, São Paulo, 2002.

PIETRI, E. Ensino da escrita na escola: processos e rupturas. Cadernos de Educação, Pelotas, n. 37, p. 133-160, set./dez. 2010.

PINTO, M. G. L. C. A escrita académica: um jogo de forças entre a geração de ideias e a sua concretização. Signo, Santa Cruz do Sul, v. 41, p. 53-71, mar. 2016. Disponível em: https://online.unisc.br/seer/index.php/signo/article/view/7325. Acesso em: 24 mar. 2020.

POSSENTI, S. Indícios de autoria. Perspectiva, Florianópolis, v. 20, n. 1, p. 105-124, jan./jun. 2002.

POSSENTI, S. Notas sobre a questão da autoria. Matraga, Rio de Janeiro, v. 20, n. 32, p. 239250, jan./jun. 2013. Disponível em: http://www.epublicacoes.uerj.br/index.php/matraga/article/view/19851. Acesso em: 16 abr. de 2019.

POSSENTI, S. Os limites do discurso: ensaios sobre o discurso e o sujeito. Curitiba: Criar Edições, 2002.

REZENDE, L. M. Atividade epilingüística e o ensino de língua portuguesa. Revista do GEL, v. 5, n. 1, p. 95-108, 2008.

RIBEIRO, D. M. Da prescrição do apostilado do Estado de São Paulo à produção de notícia: múltiplos caminhos. 2015. 150f. Dissertação (Mestrado em Letras) - Faculdade de Filosofia, Letras e Ciências Humanas, Universidade de São Paulo, São Paulo, 2015.

RIBEIRO, N. B. Autoria no domínio de gêneros discursivos: paráfrase e estilo. Linguagem em (Dis)curso, v. 6, n. 1, p. 83-99, set. 2010. Disponível em: http://portaldeperiodicos.unisul.br/index.php/Linguagem_Discurso/article/view/323. Acesso em: 24 mar. 2020.

RIBEIRO, V. V. Memória, paráfrase e polissemia em diários de leituras: análise dos gestos de interpretação de estudantes do ensino médio. Revista Memorare, v. 5, n. 2, p. 58-82, ago. 2018 . 
http://www.portaldeperiodicos.unisul.br/index.php/memorare_grupep/article/view/6728. Acesso em: 24 mar. 2020.

RIOLFI, C. R.; BARZOTTO, V. H. Alunos que erram: os paradoxos entre o uno e o múltiplo na produção textual. In: MRECH, L. M.; PEREIRA, M. R. (Orgs.). Psicanálise, transmissão e formação de professores. Belo Horizonte: Fino Traço/FAPEMIG, 2011. p. 91-102.

RIOLFI, C. R.; D’ALESSANDRO, S. L. Reescrita de textos-fonte e autoria: serão mesmo incompatíveis? Línguas \& Letras, v. 20, p. 207-223, 2019.

RIOLFI, C. R.; MAGALHÃES, M. M. M. Modalizações nas posições subjetivas durante o ato de escrever. Estilos Da Clinica, São Paulo, v. 13, n. 24, p. 98-121, 2008.

ROSSI-LANDI, F. A linguagem como trabalho e como mercado: uma teoria da produção e da alienação linguísticas. Tradução de Aurora Fornoni Bernardini. São Paulo: DIFEL, 1985.

SANTOS, J.; CAVALCANTE, V.; LIRA, J. O ensino da linguagem escrita no Ensino Fundamental: uma análise sobre a reescrita de contos. In: COLÓQUIO INTERNACIONAL DE PESQUISA EM EDUCAÇÃO SUPERIOR: SABERES, TECNOLOGIAS E OS DESAFIOS PARA A FORMAÇÃO, 3., 2015, João Pessoa. Anais... João Pessoa: UFPB, 2015. Disponível em: http://www.coipesu.com.br/upload/trabalhos/2015/12/o-ensino-dalinguagem-escrita-no-ensino-fundamental-uma-analise-sobre-a-reescrita-de-contos.pdf. Acesso em: 13 abr. 2019.

SANTOS, M. L. P. A paráfrase e a paródia em uma crônica do Millôr. Linguagem em (Re)vista, Niterói, n. 13/14, 2012.

SÃO PAUlO (SP). Secretaria Municipal de Educação. Caderno da Cidade: saberes e aprendizagens. Língua Portuguesa $-6^{\circ}$ ano - volume 1. São Paulo: SME / COPED, 2018.

SILVA, F. M. A construção do sentido nas aulas de língua portuguesa: o trabalho com leitura e escrita por meio do gênero crônica e da paráfrase no ensino médio. 2017. 80f. Monografia (Graduação em Letras - Língua Portuguesa) - Centro de Ciências Humanas, Letras e Artes, Universidade Federal da Paraíba, João Pessoa, 2017. 
SIPAVICIUS SEIDE, M. Descrição de eventos de letramento no primeiro ano de um curso de graduação. Domínios de Lingu@gem, v. 12, n. 1, p. 67-91, mar. 2018.

SMOLKA, A. L. B. A criança na fase inicial da escrita: a alfabetização como processo discursivo. São Paulo: Cortez, 1988.

SÓHISTÓRIA. João-de-barro. http://www.sohistoria.com.br/lendasemitos/joaodebarro/. Acesso em: 06 maio 2019.

SOUZA, J. C. R. Escrita e autoria: vozes que constituem e atravessam o discurso do sujeito-professor. 2010. 148f. Dissertação (Mestrado em Psicologia) - Faculdade de Filosofia, Ciências e Letras de Ribeirão Preto, Universidade de São Paulo, Ribeirão Preto, 2010.

SUASSUNA, L. Instrumentos de avaliação em Língua Portuguesa: limites e possibilidades. In: MARCUSCHI, B.; SUASSUNA, L. Avaliação em Língua Portuguesa: contribuições para a prática pedagógica. Belo Horizonte: Autêntica, 2007. p. 112-125.

TOLKIEN, J. R. R. O Hobbit. São Paulo: Martins Fontes, 2013.

TOLKIEN, J. R. R. O senhor dos anéis. São Paulo: Martins Fontes, 2001.

UNIVERSIDADE DE SÃO PAULO. Faculdade de Educação. Escola de Aplicação. Plano escolar. São Paulo, 2016.

URIBE, V. (Org.). Contos de assombração. São Paulo: Editora Ática, 1999.

VAZ, M. C. Modos de ler e dizer do sujeito: paráfrase, gestos de interpretação e autoria nas licenciaturas em letras e pedagogia. 2008. 323f. Tese (Doutorado em Educação) Faculdade de Educação, Universidade de São Paulo, São Paulo, 2008.

VILA, M. A rainha da bateria. Ilustrações de Marcelo D’Salete. São Paulo: Lazuli infantil, 2009.

WILSON, V.; ABREU, A. R. Letramento acadêmico: a construção de paráfrases em resenhas. SOLETRAS, n. 20, p. 76-90, dez. 2010. Disponível em: https://www.epublicacoes.uerj.br/index.php/soletras/article/view/5166. Acesso em: 24 mar. 2020. 


\begin{abstract}
Anexos
No que se segue, estão reproduzidos, na íntegra, os textos-fonte mobilizados nas avaliações de fevereiro, abril, agosto e novembro e o modelo do termo de autorização para uso das produções dos participantes de pesquisa distribuído aos seus responsáveis.
\end{abstract}




\section{Anexo A}

\section{A rainha da bateria ${ }^{1}$}

Maria Luisa, filha da dona Luzia, era uma menina que gostava de música brasileira samba, chorinho, bossa nova, canção, calango, baião, xote...

Pegou o gosto pela MPB com o pai, que tinha discos dos nossos grandes artistas. Ele os passou para um iPod e deu de presente para a filha.

Maria Luisa morava numa casa de subúrbio, próxima à quadra de uma escola de samba. Da janela ouvia o batuque e dormia balançando o corpo no embalo do ritmo. A família também se acostumou a dormir ao som da batucada.

Um dia o pai, que já estava velhinho, morreu e ela ficou muito triste. Sua mãe, bem mais jovem, ficou inconsolável e nunca mais sorriu.

Algum tempo depois Maria Luisa sonhou que o pai a levava para assistir a um desfile de carnaval, e por isso pediu para sua mãe levá-la a um ensaio da escola de samba, mas dona Luzia não levava toda cheia de preconceito:

- Mãe, me leva lá na quadra?

- Não. Lá não é lugar para você!

- Por que, mãe? Vejo sempre crianças indo para lá.

- É meninada de morro, filhos de gente que não presta.

Um dia Maria fugiu e foi para o ensaio da escola, enquanto sua mãe dormia. Ficou impressionada com pessoas de todas as idades cantando e sambando alegremente.

A menina não demorou no ensaio e dona Luzia nem percebeu quando a filha voltou.

Então Maria Luisa passou a fugir mais vezes e um dia se esqueceu da hora.

Dona Luzia acordou e saiu à procura da filha, nervosa. A todos os conhecidos que encontrava, perguntava aflita:

- Viu minha filha passar por aqui?

Depois de muitos "nãos", alguém disse:

- Sim. Foi para lá. Acho que está na quadra de ensaio da escola.

A mãe entrou na quadra, encontrou a filha sambando e tirou Maria do samba.

A partir daquela noite dona Luzia, antes de dormir, escondia a chave da porta para a menina não fugir, mas Maria saía pela janela.

\footnotetext{
${ }^{1}$ Texto-fonte da avaliação aplicada em fevereiro (VILA, 2009).
} 
Jovem e bela atraía as atenções nos ensaios. Aprendeu a sambar muito bem, mas não se demorava na quadra da escola.

Todos queriam que ela ficasse:

- Não vá agora! Fica mais um pouco!

- Tenho que ir. Mamãe não sabe que estou aqui.

E voltava para casa, pulava a janela e ia dormir.

Numa noite a mãe acordou, levantou-se para beber água, foi ao quarto da filha e ela não estava. Notou logo que Maria tinha saído pela janela e foi diretamente ao ensaio buscá-la. Encontrou a filha sambando numa roda.

- Vamos embora!

- Ah, mãe, deixa eu ficar mais um pouquinho, está tão bom...

- Nada disso. Já para casa!

Uma senhora se intrometeu:

- Sai pra lá, dona Luzia! Deixa a Maria sambar!

E todos pediam:

- Deixa! Deixa! Deixa!

A mãe não atendeu aos pedidos, Maria saiu chorando e Dona Luzia, vaiada:

- Uuuu! Uuuuuuu! Uuuuuuuuuuu!

No outro dia, dona Luzia mandou colocar uma tranca de ferro na janela.

Maria, que era uma menina alegre, tornou-se uma jovem adolescente muito triste. Só tinha ânimo para ir à escola porque gostava de estudar. As suas maiores notas eram de História, que ela aprendeu com os sambas-enredo, principalmente os antigos, cujas letras relatavam a Descoberta do Brasil, a Independência, a Abolição da Escravatura, a República...

Estudiosa, com dezessete anos entrou na Faculdade de Comunicação para ser jornalista.

Silas, um amigo de turma que era compositor de uma grande escola de samba, rapaz simples e muito cativante, educado e alegre, a convidou para ir a um ensaio. Maria foi, sambou muito e virou atração. Todos foram muito gentis com ela.

O mestre-sala ofereceu-lhe o estandarte:

- Quer dançar um pouquinho com a bandeira? Vai gostar.

- Não, muito grata. Acho bonita a dança, mas não quero. 
Passou algum tempo, e a moça foi se apaixonando cada vez mais pelo samba, e pelo colega Silas também, que lhe mostrava coisas lindas sobre o carnaval. Os dois começaram a namorar e a frequentar a escola de samba juntos.

Um dia o carnavalesco, aquele que é responsável pelo visual da escola, queria que ela desfilasse em um carro alegórico:

- Você é muito bela e, com uma fantasia linda, fará muito sucesso. Quer ser um dos destaques?

Delicadamente também recusou:

- Desculpe. Se desfilar, prefiro no chão.

Ofereceram-lhe a fantasia de uma das alas, a Ala das Moças, mas ela desculpou-se e disse que gostaria de sambar livremente. Então o Diretor de Harmonia a levou para a roda de passistas; ela sambou, se destacou e foi apresentada ao Diretor de Bateria que, como um maestro, regia seus músicos - dois surdos grandes de primeira, quatro de segunda, repiques, caixas, taróis, tamborins, pandeiros, cuícas, chocalhos, reco-recos, xequeréis... E Maria Luisa, sambando com muita graça, encantou os batedores.

Foi aclamada:

- Rainha! Rainha! Rainha!

Atualmente, ela desfila na frente dos ritmistas como Rainha da Bateria e fotos dela são publicadas em jornais, para orgulho da sua mãe. É que dona Luzia perdeu o preconceito, começou a gostar de samba e retomou a alegria de viver, depois que a filha se casou com Silas e eles tiveram uma filha linda.

Em todo carnaval Maria Luisa reina na bateria. Sua mãe desfila na Ala das Baianas e sua filha é porta-bandeira da escola mirim.

Escola de Samba é um teatro ambulante. Num bom desfile está presente uma profusão de artes - pintura, escultura, artesanato, cenografia, literatura, poesia, música e dança.

É por isso que muita gente, como Maria Luisa, se apaixona pelas Escolas de Samba e nunca mais deixa de desfilar! 


\section{Anexo B}

\section{João-de-barro ${ }^{2}$}

Contam os índios que foi assim que nasceu o pássaro joão-de-barro.

Segundo a lenda, há muito tempo, numa tribo do sul do Brasil, um jovem se apaixonou por uma moça de grande beleza. Jaebé, o moço, foi pedi-la em casamento.

O pai dela então perguntou:

- Que provas podes dar de sua força para pretender a mão da moça mais formosa da tribo?

- A prova do meu amor! - respondeu o jovem Jaebé.

O velho gostou da resposta, mas achou o jovem atrevido, então disse:

$-\mathrm{O}$ último pretendente de minha filha falou que ficaria cinco dias em jejum e morreu no quarto dia.

- Pois eu digo que ficarei nove dias em jejum e não morrerei.

Toda a tribo se admirou com a coragem do jovem apaixonado. O velho ordenou que se desse início à prova. Então, enrolaram o rapaz num pesado couro de anta e ficaram dia e noite vigiando para que ele não saísse nem fosse alimentado. A jovem apaixonada chorava e implorava à deusa Lua que o mantivesse vivo. O tempo foi passando e certa manhã, a filha pediu ao pai:

- Já se passaram cinco dias. Não o deixe morrer.

E o velho respondeu:

- Ele é arrogante, falou nas forças do amor. Vamos ver o que acontece.

Esperou então até a última hora do novo dia, então ordenou:

- Vamos ver o que resta do arrogante Jaebé.

Quando abriram o couro da anta, Jaebé saltou ligeiro. Seus olhos brilharam, seu sorriso tinha uma luz mágica. Sua pele estava limpa e tinha cheiro de perfume de amêndoas. Todos se admiraram e ficaram mais admirados ainda quando o jovem, ao ver sua amada, se pôs a cantar como um pássaro enquanto seu corpo, aos poucos, se transformava num corpo de pássaro!

\footnotetext{
${ }^{2}$ Texto-fonte da avaliação aplicada em abril (SÓHISTÓRIA, 2019).
} 
E foi naquele exato momento que os raios do luar tocaram a jovem apaixonada, que também se viu transformada em um pássaro. E, então, ela saiu voando atrás de Jaebé, que a chamava para a floresta onde desapareceram para sempre.

Podemos constatar a prova do grande amor que uniu esses dois jovens no cuidado com que o joão-de-barro constrói sua casa e protege os filhotes. Os homens admiram o pássaro joão-de-barro porque se lembram da força de Jaebé, uma força que nasceu do amor e foi maior que a morte. 


\section{Anexo C \\ Maria Angula(Equador) $)^{3}$}

Maria Angula era uma menina alegre e viva, filha de um fazendeiro de Cayambe. Era louca por uma fofoca e vivia fazendo intrigas com os amigos para jogá-los uns contra os outros. Por isso tinha fama de leva e traz, linguaruda, e era chamada de moleca fofoqueira.

Assim viveu Maria Angula até os dezesseis anos, dedicada a armar confusão entre os vizinhos, sem ter tempo para aprender a cuidar da casa e a preparar pratos saborosos.

Quando Maria Angula se casou começaram seus problemas. No primeiro dia, o marido pediu-lhe que fizesse uma sopa de pão com miúdos, mas ela não tinha a menor ideia de como prepará-la.

Queimando as mãos com uma mecha embebida em gordura, ascendeu o carvão e levou ao fogo um caldeirão com água, sal e colorau, mas não conseguiu sair disso: não fazia ideia de como continuar.

Maria lembrou-se então de que na casa vizinha morava dona Mercedes, cozinheira de mão-cheia, e, sem pensar duas vezes, correu até lá.

- Minha cara vizinha, por acaso a senhora sabe fazer sopa de pão com miúdos?

- Claro, dona Maria. É assim: primeiro coloca-se o pão de molho em uma xícara de leite, depois despeja-se este pão na panela e, antes que ferva, acrescentam-se os miúdos.

- Só isso?

- Só, vizinha.

- Ah - disse Maria Angula - mas isso eu já sabia!

E voou para sua cozinha a fim de não esquecer a receita.

No dia seguinte, como o marido lhe pediu que fizesse um ensopado de batatas com toicinho, a história se repetiu:

- Dona Mercedes, a senhora sabe como se faz o ensopado de batatas com toicinho?

E como da outra vez, tão logo a sua boa amiga lhe deu todas as explicações, Maria Angula exclamou:

- Ah! É só? Mas isso eu já sabia! - E correu imediatamente para casa a fim de prepará-lo.

\footnotetext{
${ }^{3}$ Texto-fonte da avaliação aplicada em agosto (URIBE, 1999).
} 
Como isso acontecia todas as manhãs, dona Mercedes acabou se enfezando. Maria Angula vinha sempre com a mesma história: "Ah é assim que se faz o arroz com carneiro? Mas isso eu já sabia! Ah, é assim que se prepara a dobradinha? Mas isso eu já sabia!" Por isso a mulher decidiu dar-lhe uma lição e, no dia seguinte...

- Dona Mercedinha!

- O que deseja, Dona Maria?

- Nada, querida. Só que o meu marido quer comer no jantar caldo de tripas e bucho e eu...

— Ah!, mas isso é fácil demais! - disse dona Mercedes. E antes que Maria Angula a interrompesse, continuou:

- Vá ao cemitério levando um facão bem afiado. Depois espere chegar o último defunto do dia, e sem que ninguém a veja, retire as tripas e o estômago dele. Ao chegar em casa, lave-os muito bem e cozinhe-os com água, sal e cebolas. Depois que ferver uns dez minutos, acrescente alguns grãos de amendoim e está pronto. É o prato mais saboroso que existe.

- Ah! - disse Maria Angula - É só? Mas isso eu já sabia!

E, num piscar de olhos, estava ela no cemitério, esperando pela chegada do defunto mais fresquinho. Quando já não havia mais ninguém por perto, dirigiu-se em silêncio à tumba escolhida. Tirou a terra que cobria o caixão, levantou a tampa e... Ali estava o pavoroso semblante do defunto! Teve ímpetos de fugir, mas o próprio medo a deteve ali. Tremendo dos pés à cabeça, pegou o facão e cravou-o uma, duas, três vezes na barriga do finado e, com desespero, arrancou-lhe as tripas e o estômago. Então voltou correndo para casa. Logo que conseguiu recuperar a calma, preparou a janta macabra que, sem saber, o marido comeu lambendo os beiços.

Nessa mesma noite, enquanto Maria Angula e o marido dormiam, escutaram-se uns gemidos nas redondezas.

Ela acordou sobressaltada. O vento zumbia misteriosamente nas janelas, sacudindo-as, e de fora vinham uns ruídos muito estranhos, de meter medo a qualquer um.

De súbito, Maria Angula começou a ouvir um rangido nas escadas. Eram os passos de alguém que subia em direção ao seu quarto, com um andar dificultoso e retumbante, e que se deteve diante da porta. Fez-se um minuto eterno de silêncio e logo depois Maria Angula viu o resplendor fosforescente de um fantasma. Um grito surdo e prolongado paralisou-a. 
- Maria Angula, devolva minhas tripas e o meu estômago, que você roubou da santa sepultura!

Maria Angula sentou-se na cama, horrorizada, e, com os olhos esbugalhados de tanto medo, viu a porta se abrir, empurrada lentamente por essa figura luminosa e descarnada.

A mulher perdeu a fala. Ali, diante dela, estava o defunto, que avançava mostrandolhe o seu semblante rígido e o seu ventre esvaziado.

- Maria Angula, devolva as minhas tripas e o meu estômago, que você roubou da minha santa sepultura!

Aterrorizada, escondeu-se debaixo das cobertas para não vê-lo, mas imediatamente sentiu umas mãos frias e ossudas puxarem-na pelas pernas e arrastarem-na gritando:

- Maria Angula, devolva as minhas tripas e o meu estômago, que você roubou da minha santa sepultura!

Quando Manuel acordou, não encontrou mais a esposa e, muito embora tenha procurado por ela em toda parte, jamais soube do seu paradeiro. 


\section{Anexo D}

\section{Uma festa muito esperada ${ }^{4}$}

Quando Bilbo Bolseiro anunciou que celebraria seus 111 anos de idade, no dia 22 de setembro, com uma festa de especial grandeza, houve muito comentário e agitação na Vila dos Hobbits.

Bilbo era muito rico e tinha sido a atração do Condado por sessenta anos, desde seu extraordinário desaparecimento e inesperado retorno. As riquezas de suas viagens tinham se tornado uma lenda local, e acreditava-se que a Colina estava cheia de túneis recheados de tesouros

Ele não tinha amigos íntimos, até que seus primos mais jovens começaram a crescer. O mais velho deles, e favorito de Bilbo, era o jovem Frodo Bolseiro. Quando Bilbo tinha noventa e nove anos, adotou Frodo como seu herdeiro, e o trouxe para viver com ele. Por acaso, Bilbo e Frodo faziam aniversário no mesmo dia.

No final da segunda semana de setembro chegou na Vila dos Hobbits uma charrete conduzida por um homem que usava chapéu azul, alto e pontudo, uma longa capa cinza, um cachecol prateado, uma longa barba branca e sobrancelhas grossas que sobressaíam da borda de seu chapéu. O homem descarregou grandes pacotes de fogos de artifício de todos os tipos e formatos na porta da frente de Bilbo. Grande companheiro de aventura do hobbit, Gandalf tinha sido convidado para a festa de aniversário dele.

O grande dia chegou e Bilbo recebeu pessoalmente todos os convidados e distribuiu presentes para todos. Os hobbits dão presentes para outras pessoas em seus aniversários, em geral, presentes não muito caros.

Quando todos os convidados tinham recebido as boas-vindas e estavam finalmente do lado de dentro da festa, houve canções, danças, música, jogos e, é claro, comida e bebida.

Houve três refeições oficiais: almoço, chá e jantar. Todos comeram e beberam das onze até às seis e meia da tarde, quando os fogos de artifício começaram.

Depois do banquete veio o Discurso...

- Meus queridos Bolseiros e Boffins, e meus queridos Tûks e Brandebuques e Fossadores e Roliços e Covas e Corneteiros e Bolgers, Justa-correias, Boncorpos, Texugos e

\footnotetext{
${ }^{4}$ Texto-fonte da avaliação aplicada em novembro (TOLKIEN, 2001).
} 
Pé-soberbos. E também meus bons Sacolas-bolseiros, a quem finalmente dou boas-vindas novamente. Hoje é meu centésimo décimo primeiro aniversário!

- Viva! Viva! Que essa data se repita por muitos anos! - gritaram todos, e bateram nas mesas alegremente.

- Espero que estejam se divertindo tanto quanto eu. Chamei todos vocês por três motivos! Primeiramente, para dizer a vocês que gosto imensamente de todos. Em segundo lugar, para comemorar meu aniversário e de meu herdeiro e primo Frodo. Hoje ele se torna maior de idade e passa a ter a posse da minha herança. Hoje também é o aniversário de minha chegada de barril a Cidade do Lago, no Lago Comprido. Eu tinha apenas cinquenta e um anos naquele tempo, e os aniversários não pareciam tão importantes. Em terceiro lugar e finalmente, quero comunicar que estou indo embora. Adeus!

Desceu da cadeira e desapareceu. Houve um clarão de luz de cegar os olhos e todos os convidados piscaram. Quando abriram os olhos, Bilbo não estava em lugar algum. Cento e quarenta e quatro hobbits espantados se encostaram nas cadeiras sem dizer nada.

Os convidados acharam que a brincadeira de Bilbo tinha sido de muito mau gosto, e foi necessário trazer mais comida e bebida para curar a todos do choque e do desconforto.

Frodo era o único presente que não dizia nada. Por um tempo ficou sentado em silêncio ao lado da cadeira vazia de Bilbo e ignorou todos os comentários e perguntas. Tinha gostado da brincadeira, é claro, mesmo já estando a par de tudo.

Teve dificuldades para segurar o riso diante da irritação dos convidados. Mas ao mesmo tempo sentia-se numa encrenca: percebeu de repente que adorava o velho hobbit. A maioria dos convidados continuou comendo e bebendo e discutindo as esquisitices de Bilbo Bolseiro, passadas e atuais.

A verdade é que quando Bilbo desceu da cadeira e desapareceu, foi rapidamente de volta para sua toca sem ser visto por ninguém. Tirou a roupa de festa, dobrou e embrulhou em papel crepom seu colete de seda bordado e o guardou. Vestiu rapidamente umas roupas velhas e desarrumadas, e apertou em volta da cintura um velho cinto de couro. Nele pendurou uma pequena espada que estava numa bainha de couro preta e gasta. De uma gaveta trancada, cheirando a naftalina, retirou uma velha capa e um capuz. Eles tinham sido guardados ali como se fossem muito preciosos, mas estavam tão remendados e manchados que mal se podia adivinhar a cor original: provavelmente verde-escuro. Eram grandes demais para ele.

Então Bilbo entrou no escritório e de uma grande caixa-forte tirou um pacote embrulhado em panos velhos e um livro escrito a mão com capa de couro; e também um 
envelope grande. O livro e o pacote ele colocou em um saco pesado que estava ali, já quase cheio. No envelope colocou o anel de ouro, e sua fina corrente, e então o selou e endereçou a Frodo. Primeiro colocou-o sobre a lareira, mas de repente retirou-o dali e o enfiou no bolso. Naquele momento a porta se abriu e Gandalf entrou depressa.

Bilbo disse a Gandalf que tiraria férias permanentes e que não voltaria mais à Vila dos Hobbits. Contou que queria ver o campo selvagem e as montanhas antes de morrer. Bolseiro informou que levaria consigo o anel mágico, mas Gandalf tentou convencê-lo do contrário.

O hobbit ficou parado por um momento, nervoso e indeciso. Depois suspirou e decidiu:

- Muito bem, o anel vai para Frodo, com todo o resto da herança. E agora devo ir, ou alguém vai me pegar. - Apanhou seu saco e se dirigiu para a porta.

Um tempo depois de Bilbo ter se despedido de Gandalf e ter ido embora, Frodo entrou na casa e encontrou Gandalf pensativo sentado no escuro.

O mago contou a Frodo que Bilbo havia partido e que tinha deixado para ele o testamento, todos os outros documentos e o anel de ouro.

- O anel! - exclamou Frodo. — Ele me deixou o anel? Gostaria de saber por quê! Mas ele ainda pode ser útil!

- Tome cuidado com esse anel, Frodo! Coisas estranhas podem acontecer com pessoas que possuem esse tipo de tesouro - se elas o usarem. Esse anel pode ter mais poderes do que simplesmente fazer você desaparecer quando desejar.

- Não entendo - disse Frodo.

- Eu também não, por isso não vou dizer mais nada. Pode ser que eu tenha alguma coisa para dizer quando voltar. Posso ficar longe por um bom tempo, mas volto para ver você de novo assim que puder. Quando você menos esperar, eu vou aparecer! Chegarei em silêncio.

Frodo o acompanhou até a porta. Ele acenou pela última vez e começou a andar num passo surpreendente. A noite estava chegando e o seu vulto desapareceu com os últimos raios solares daquele dia. Frodo não o viu novamente por um longo tempo. 


\section{Anexo E}

\section{TERMO DE AUTORIZAÇÃO}

Faculdade de Educação da Universidade de São Paulo

Site: http://paje.fe.usp.br/ geppep/index.htm

Contato: geppep@usp.br

$\mathrm{Eu}$, (responsável), abaixo assinado e qualificado, tenho ciência e concordo, inequívoca e expressamente, que cópias dos rascunhos produzidos por (aluno/a) e doados aos pesquisadores do projeto de pesquisa Movimentos do Escrito, membros do Grupo de Estudos e Pesquisa Produção Escrita e Psicanálise - GEPPEP, vinculado à Faculdade de Educação da Universidade de São Paulo - FEUSP, sejam tomados como objeto de estudo e AUTORIZO:

1. que análises da evolução da escrita, tendo em vista o cotejamento de versões diferentes de textos, sejam publicadas em estudo científico de qualquer formato (artigos, livros, revistas, CD-rom, sites e outros), ficando preservada a divulgação da identidade e/ou foto; e

2. que alguns fragmentos dos rascunhos sejam reproduzidos a título de exemplo em exposições orais (comunicações, palestras, conferências e similares) e/ou em textos impressos.

São Paulo, de de

Ciente e de acordo,

Nome do aluno:

CPF do aluno: RG do aluno:

\begin{tabular}{|l|l|}
\hline Nome do representante legal: & Assinatura do representante legal: \\
\hline CPF do representante legal: & RG do representante legal: \\
\hline
\end{tabular}

Endereço:

Telefone: 